Historic, archived document

Do not assume content reflects current scientific knowledge, policies, or practices. 
62,73 सुlBRIDGED EDHIION, SPRING 1892.
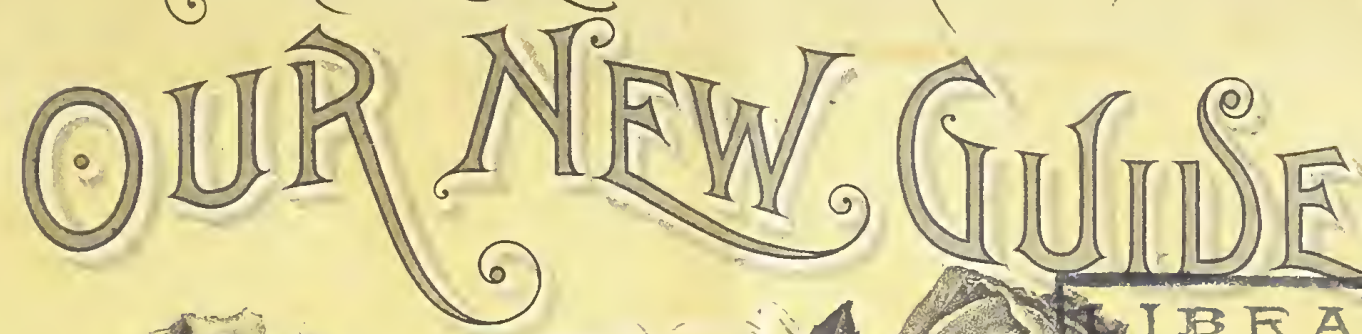

sin

int

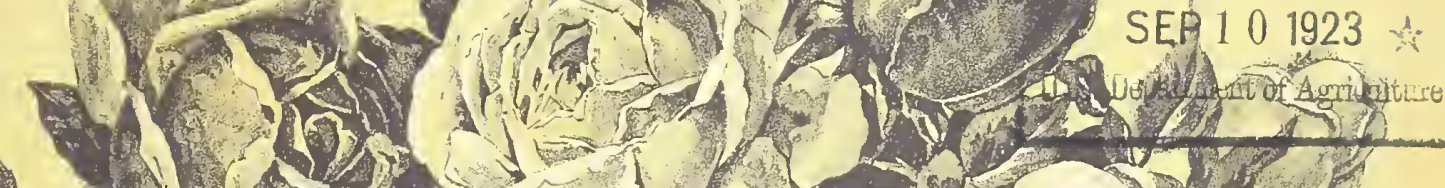

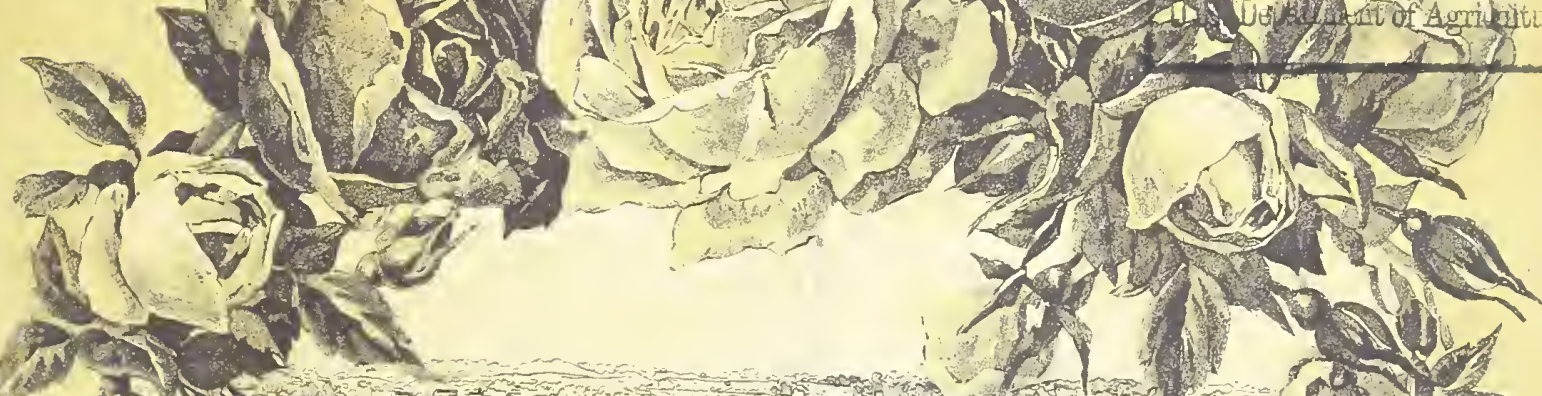
(1) 10 . 3 .

$11 \times 12=5$

1010 .

$2 \pi+2+2 \pi$

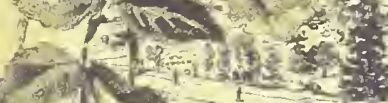

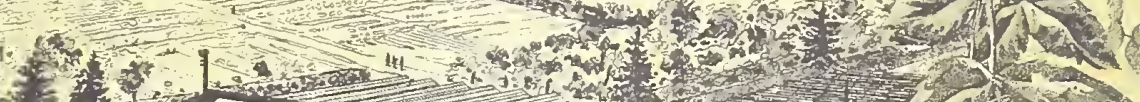

1 . (1) 10

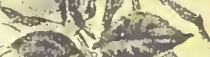

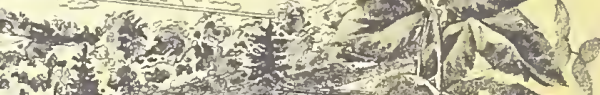

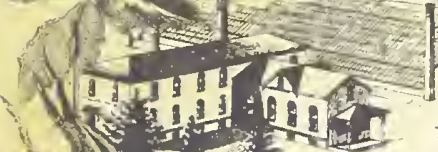

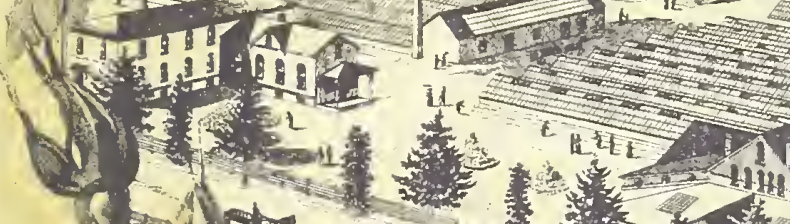

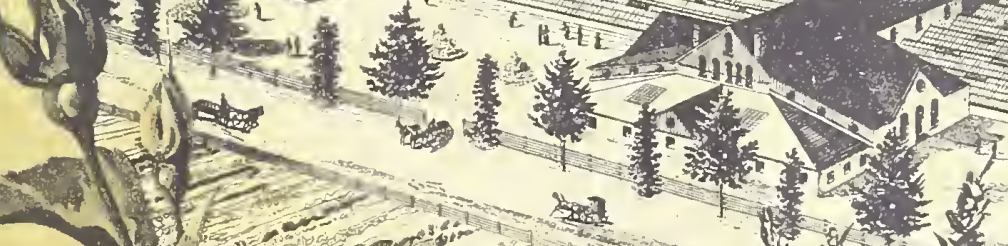

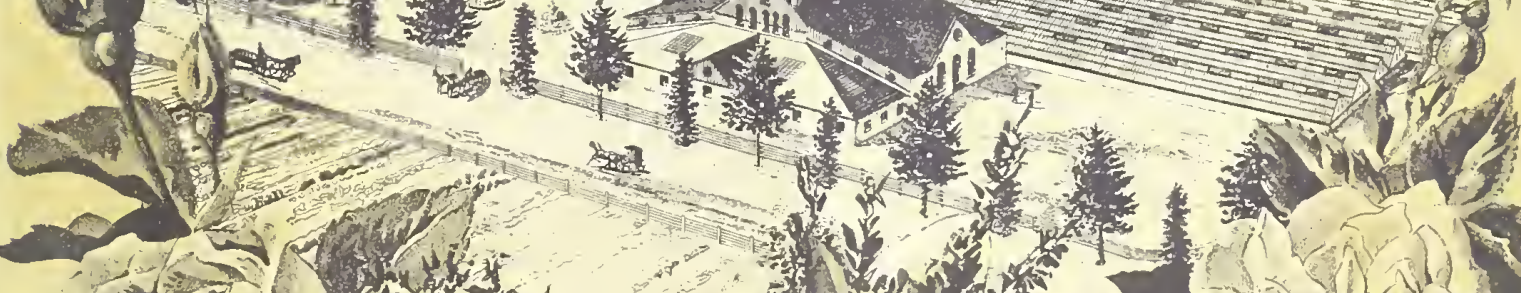
(1)

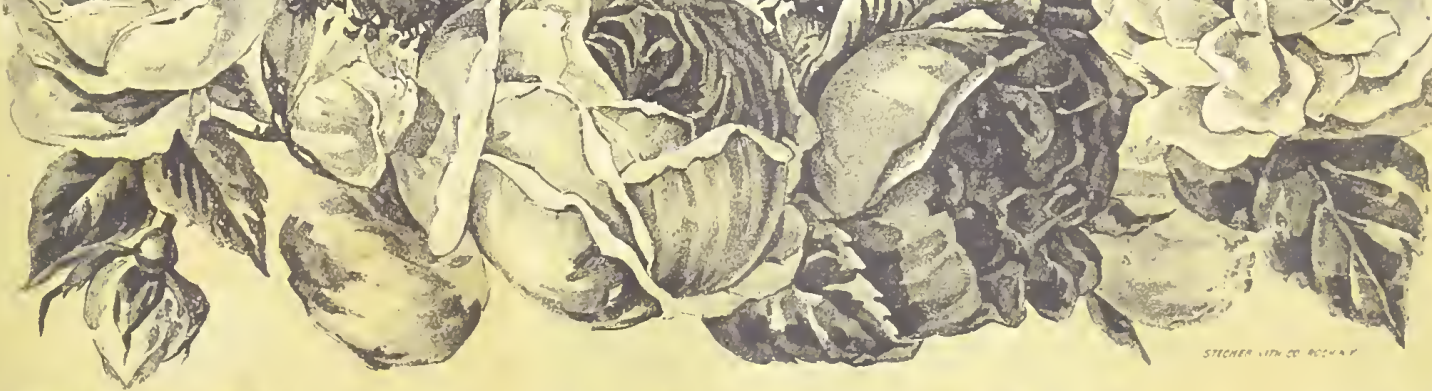
(6) (2)
Diingere
WEST
of Gol?âd
Gom
painy.
Grove, Pa. 


\section{INFORMATION FOR PURCHASERS.}

MOW TO SEND MONEY SAFELY.

Our Prices are Strictly Cash.-The proper remittance must in all cases accompany the order and should be enclosed with it

MONEY AT OUR RISK.-All money sent us by Postoffice Money Order (not Postal Note) on West Grove P. O., Pa.; Bank, Drafts on any city bank; Express Money Order or Registered Letter is at our risk, and we will be responsible for its safe arrival, and will send full value for it in all cases.

POST-OFFICE MONEY ORDERS ean now be had at most all Post-offices, ard are absolutely safe. If the letter enclosing it is lost, send us the number, date and amount, the office at which it was payable, a list of what you ordered, and we will fill the order at once, and apply for a duplicate of the lost Money Order, which the Government will furnish in such cases.

BANK DRAFTS, drawn on any city bank and made payable to our order, are good, and can be had at all banks. If lost, the bank will issue a duplicate.

EXPRESS MONEY ORDERS are one of the cheapest and best ways of sending us Money. Perfectly safe, because if lost a duplicate can be had by applying to the Express Company.

REGISTERED LETTERS.-When you cannot get Money Orders, enclose money-either notes or coin-carefully wrapped, and have it Registered by the Postmaster; the responsibility then is ours.

POSTAL NOTES are payable to bearer and no duplieates allowed; the sender assumes the risk if lost.

STAMPS.-Please do not send stamps in payment of goods. Money is much more acceptable, and you can send small amounts (under one dollar) in Silver Coin-carefully wrapped and sealed-just as safely as stamps, and much more conveniently to yourselves and us.

CANADA (see page 9).-Friends in Canada can remit by International Postal Order on West Grove P. O., Pa., Bank draft on New York, or Canadian currency in Registered Letter.

An elegant Rose presented for the Cost of Remittance.-In addition to all other premiums, we will pre sent with all orders for plants an elegant Rose for every re mittance of \$I and upwards made by Money Order, Bank Draft, Express Order or Registered Letter. This Rose will be marked $R$. on back of label.

\section{WE GUARANTEE OUR ROSES.}

Guarantee.-All Roses and plants sent out by us to points within the United States and Canada, whether by mail or express, are guaranteed to reach the purchaser in good growing condition. In case of accident, by which they are injured or spoiled in any way before delivery, we request information to be forwarded immediately, so that they may be replaced at once. Having arrived in good order, our responsibility ceases

Size and Quality of Plants.-The Roses we send are fine, strong, healthy plants-grown in pots. Many of the ever-blooming varieties are ready to bud when sent out, and will quickly come into full bloom. Where the season is suffieiently advanced they are suitable for planting at once in open ground, or they can be grown nicely in the house, in pots or boxes

OUR ROSES ALL POT GROWN.-All our Roses are Pot Grown, and specially prepared for safe transportation and inumediate bloom. They are grown in pots in ordinary fertile soil, without manure or stimulants of any kind; our design being to produce strong, healthy, well-matured plants, wel furmished with working roots. Instead of forcing then into bloom here, we aim to kecp them from blooming as much as maybe, and to get them ready and in the best possible condi. tion to orow and bloom guickly after planting out. Our Roses are not tired and needing rest, or petted and forced so that they demand unusually nice treatment, but are sent out strono and hungry, ready for work, inured to hardship, und fully prepared to battle for life, and this is one great secret of their success. YOU CANNOT EASILY KILL THEM OR KEEP THEMT FROM BLOOMING.

OUR ROSES ARE ALL ON THEIR OWN ROOTS. - All cur Roses are grown from cuttings, and are therefore all on their own Roots. If the plants incline to sprout from the root, they should be encouraged to do so, as young, vigorous shoots frequently produce the finest flowers. They camo throw up wild shoots, because root and tip are the same; and as long as any part of the plant remains, it will produce the sime beautiful flower.

NO BUDDED OR GRAFTED ROSES SENT OUT. We do not send out any budded or grafted Roses, for, not withstanding all that is said in their fuvor by those who are interested in their sale, it is well known that budded and grafted Roses generally prove an utter failure and are en tirely unreliable for general planting. ALL OUR ROSES ARE ON THEIR OWN ROOTS.

Difference in Size of Varieties.-Do not expect all arieties to be of the same size; somt are stronger growers than others, and make larger plants at the same age and under actly the same eonditions, and some of the smallest and weakest growers produce the most beautiful flowers; this

ccording to Nature, and can't be helped.

Better than we Promise.-'Though our prices are very low for the quality of the plants we offer, we always try to do a little better than we pronise, and give generous value and faithful service to all.

Presented Plants are marked $\mathrm{P}$ on back of label, and are frequently very choice sorts. Be sure to take good care of inem; they sometimes give better satisfaction than those ordered.

Purchaser's Choice of Varieties.-We endeavor to grow all varieties we offer in sufficient quantity to furnish exactly what is ordered. We always have an enormous stock select from, and try to fill all orders exactly as given.

Which are the best Varieties.-IVe cannot list of the best varieties, because those that are best for one place may not be so for another; but we will cheerfully select for purchaser's who direct us to do so: and if we are told the class of Roses wanted and the colors preferred, we can always insure satisfactory results, both in the varieties and the quality of plants.

PLANTERS who wish several hundred Roses or other plants for their own use should send a list of the varieties and number of each wanted, and we will examine carefully and give lowest prices by next mail. Ordinary orders are invariably at prices given.

ROSES READY FOR SHIPMENT AT ALI, TIMES. - Planting is always in season in some parts of the coumtr and orders are recelved and plants can be forwarded every working day in the year.

\section{HOW WE SEND ORDERS.}

Our Great Specialty is sending orders by mail, postpaid, to any post-office in the United States or Canada. We con. sider our method of packing superior, and guarantee the safe arrival of every order.

Mailing Boxes.-We pack in strong wooden boxes, with live moss filling. Though this is the most expensive way, it is the best, and therefore we use no other.

Express Orders.-For Express orders we select the largest and best plants on hand at the time, and though we do 110 promise larger Roses by Express than we send by Mail (unless 'Two-year Roses are ordered, see' page 4I), we can generally send larger shrubs and other plants, and sometimes larger Roses. Our system of packing is so complete that we can ship with perfect safety during the coldest or hottest weather, and guarantee the plants to arrive in good condition.

We Ship by Express when Directed, the purchaser paying the Express charges. Many persons prefer to have their goods sent by Express, the plants have more room in the boxes and look larger and better when opened. Besides this, a portion of the earth can be lcft on the roots, which some consider a great advantage. Large orders should always be sent by Express when plants are wanted in best condition and the expense is not an objection: but we can send small orders of ordinary size Roses and plants, long or short distances, just as safely and satisfactorily by Mail, and save the pur. chaser the Express charges.

Correction of Errors. - We take all possible eare to avoid elrors, and, when any occur, request information to be forwarded immediately, so that they can be corrected at once; we cannot afford, and do nct mean to have a single customer dissatisfied, if prompt and carcful attention to his wants will prevent it 


\section{FOUR VALUABLE TEA ROSES, INTRODUCED BY \\ THE DINGEE \& CONARD COMPANY.}

Perhaps one of the most interesting features of our business from an outside view is the constant quest for New and superior varieties of Roses; no difference what part of the world they come from, if they are distinct from and really superior to older sorts, we spare neither trouble nor expense to obtain them. Besides the choicest European Novelties which we import regularly every year at large expense, we are constantly on the watch for meritorious New Roses which originate in this country, and it sometimes happens that the most valuable New Roses of the year are produced here, and not abroad. New Varieties are sometimes chance seedlings or else sports or variations from old well-known kinds, but when produced by artificial hybridization, it is a work requiring much careful skill, and perhaps years of patient labor before any new variety worth keeping can be found. Our house is always foremost in introducing New Varieties of real merit, and we now bring forward another candidate for public favor, a superb crimson Tea Rose, which we have named in honor of the daughter of the senior member of our Company.

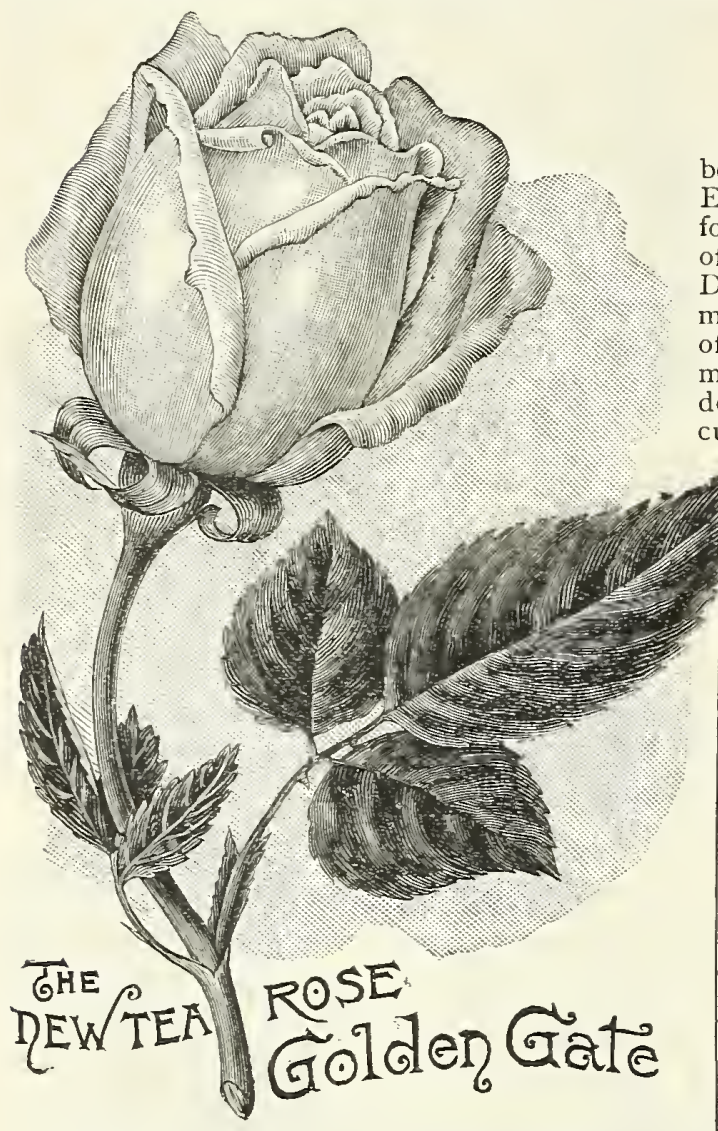

New Tea Rose, Golden Gate.

There are so many beautiful Roses, and they are beautiful in so many different ways, that it scarcely seems possible for any one variety to be the most beautiful of all Roses; and yet if the question was to be decided we are strongly of the belief that the palm would have to be awarded to our New Tea Rose-Golden Gate-introduced by us last year. A cross between Safrano and Cornelia Cook, combining the good qualities of both. The flowers are extra large, and finely formed, and of excellent substance; the buds are long and of the most desirable form ; the color is rich creamy white, beautifully tinged with fine golden yellow; the petals are large and broad, and exquisitely bordered and tinted with clear rose. The Golden Gate is a strong healthy grower, and a most profuse and continuous bloomer; wrill produce more perfect buds and bloom than almost any variety we know. $35 \mathrm{cts}$. each; 3 for $\$ \mathrm{I}$.

\section{New Crimson Tea Rose, Marion Dingee.}

This grand New Rose was raised from seed of the beautiful Countess de Casserta, crossed with Duchess of Edinburgh. The Casserta blood is shown most in its foliage and habit of growtl, while the flowers have much of the brilliant coloring and somewhat the form of Duchess of Edinburgh, but are altogether different and much more striking. MARION DINGEE promises to be of extraordinary value; it is a strong, vigorous grower, making a handsome graceful bush; with large, thick, deep green leaves; the flowers are large, beautifully cup-shaped, moderately full, and borne in wonderfui profusion all through the growing season; in fact, we scarcely know of any other Rose that will produce so many perfect flowers in a given time; and whether in open ground or under glass it is a most constant and profuse bloomer; the flowers are borne nearly upright on long straight stems, and are of excellent substance, having thick leathery petals which hold their form and color for a long time; the color is perhaps its most remarkable feature; it is deep brilliant crimson, one of the darkest, if not the very darkest and richest colored Tea Rose in existence, and we have no hesitation in asserting our belief that it is the finest crimson Tea Rose now known. We put the price as low as possible so it will be within the easy reach of all. 40 cts. each; 3 for \$r.ro.

\section{Henry M. Stanley.}

This elegant new ever-blooming Tea Rose was named in honor of the great African explorer and introduced by us last year; it makes a beautiful contrast with Golden Gate, as the color is a rare and remarkably beautiful shade of clear amber rose, delicately tinged towards the centre with fine apricot yellow; the petals are beautifully edged and bordered with rich carmine, and on the outer or reverse side pass to a lovely shade of salmon or buff rose; the flowers are large, fine full form, excellent substance and deliciously fragrant, having a rich tea scent. $35 \mathrm{cts}$. each; 3 for $\$ \mathrm{I}$.

\section{Pearl Rivers.}

This fine variety is the result of a union between Devoniensis and Mad. de Watteville. It partakes of the leading characteristics of both parents, but resembles the latter most closely; the flowers are large and quite full, with fine peachy red buds; the ground color is ivory white, having the petals delicately shaded and bordered with pale rose : very beautiful; deliciously sweet. $35 \mathrm{cts}$. each ; 3 for $\$ \mathrm{I}$.

SPECIAT, OFFER.-For \$1.30 we will send, postpaid, to any Post-office, safe arrival and satisfaction guaranteed, the four lovely Tea Roses, offered on this page. 


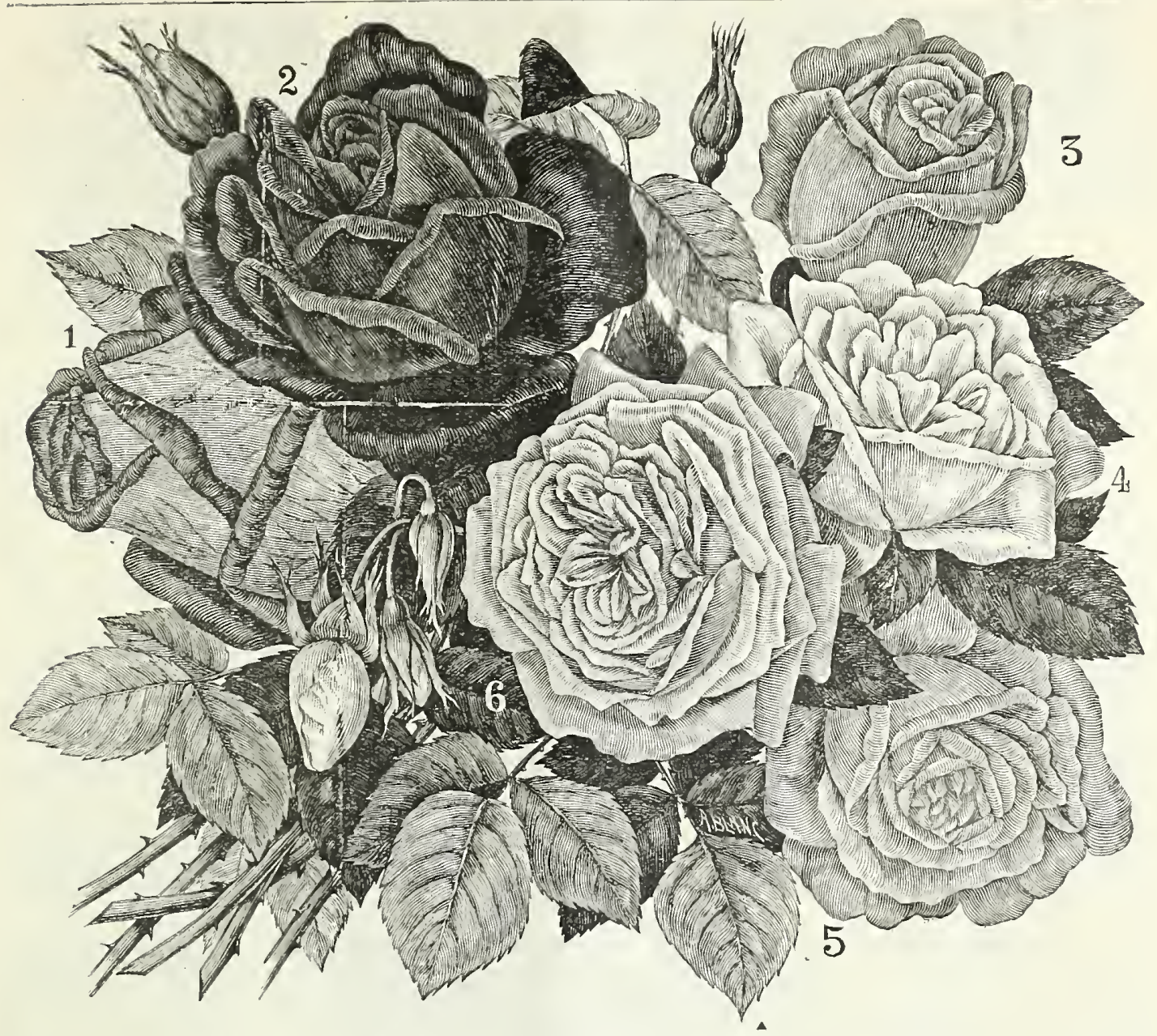

\section{SPECIAL INTRODUCTION OFFER OF THE}

\section{Dingee \& Conard Company's Famous Roses.}

To introduce our Roses to thousands of new customers, to gratify thousands of old friends who wish some of the finest Roses, to help planters who do not succeed as they would like, to encourage lovers of Roses who fear they cannot grow really fine ones, and to advertise our Roses, we make for the first time this unsurpassed offer-a collection of Ever-blooming Tea Roses, that combine the loveliest types of the Tea Rose family with vigorous, healthy growth under ordinary conditions. The past season we grew quite an area of the varieties included in this collection in the open field under the same conditions as a farm crop; the result was highly satisfactory; the plants grew sturdy and healthy, retaining full foliage even after severe storms, and the flowers were produced in great abundance and perfection from early Summer till checked by severe frost, November Ioth. The above illustration was made from a handful of flowers gathered in August, representing each variety. This collection of Roses is for everybody far and wide, and we recommend the varieties included as equal to the finest Roses. You should order it even if you wish nothing else this season. Sent postpaid, to any post-office, for only 50 cents. Safe arrival guaranteed.

PLEASE NOTICE.-The Roses offered in this collection are classified and offered at regular retail prices under heads of "New Roses, introduced in 1891," and "Ever-blooming Tea Roses," at the collection price of 50 cents here offered; the collection cannot be changed or altered for any reason.

LUCIOLE.-We need not say much of this grandly beautiful Tea Rose, as it was introduced three years ago, and is a high favorite. The buds and flowers are extra large and perfect; color, clear cherry with rich golden centre, shaded with same color; indeed the flower appears variegated cherry and gold, delight fully perfumed (cut No. I). ored Rose in the collection, remarkably brilliant and showy rich crimson with white centre: large, well-filled flowers; very fragrant and striking. This grand Rose was imported from France, and first introduced in this country last season, when it was sold at $50 \mathrm{cts}$. each (see crst No. 2).

MAD'ELLE GENEVIEVE GODARD.-Splendid for bouquets and cutting; the perfectly shaped flowers are very full, regular and sweet; the color is a clear carmine rose, and quite distinct from other varieties offered in this collection (sec cut No. 3).

FOR 50 CENTS we will send, postpaid, to any Post-office, and guarantee safe arrival and satisfaction, the Six Grand Tea Roses described above. Club Terms, 6 Collections for $\$ 2.50$; I2 for $\$ 5$.
MADAME MARTHE DuBOURG.-New $180 \mathrm{r}$, and sold for $50 \mathrm{cts}$. each; a wonderfully pretty Tea Rose; the exquisitely crimped petals color creamy white, centreof lace; this is poorly shown in illustration; FRANCISCA KRUGER. - This valuable Tea Rose will please all the splendid flowers are deeply shaded coppery tollow in color, and are very large and symmetrically shaped, very fragrant and lasting troduced last year and sold for $50 \mathrm{cts}$. each. It is entirely distinct and a superbly beautiful Rose; color chrome yellow, elegantly tinged with orange, passing to buff flushed with rose; buds and outer petals (sec cut No. 6). DUCHESSE MARIE SALVIATI.-This grand Rose was first in - 


\section{THE MOST FOR THE MONEY.}

If you want the most for the money, order from this page. The stock offered is as good as any we have; We guarantee this, and warrant all sets to reach all Post-offices in the United States and Canada in good growing condition. Knowing that our Roses, Plants and Seeds are our best advertisement, we annually prepare enormous stocks for these collections; they make thousands of new customers, and we say once a customer always a customer. Each article in each collection is distinctly labeled, and no two varieties alike in the same collection.

All collections by Mail, postpaid, at prices named.

NOTICE.-In ordering collections, Purchasers will invariably order by NUMBER ONLY.

\section{Roses on their Own Roots.}

We will send you Roses that will grow and bloom. We have the know how of growing them, keeping them, shipping tbem-acres of glass. If you really like Roses, you are bound to come to us in the glass. The following sets make it easy to have some Roses :

\section{A Bed of Roses for \$r.}

SET No. 1.-A Bed of 16 Beautiful Ever-blooming Roses for \$1. We will carefully select to suit your locality I 6 beautiful Ever-bloom ing Roses in Í different varieties, each one labeled. If you want Rose Buds from June till November, get this set for $\$ \tau$. If you have no room in the front yard, plant the 16 in the garden. The constant no room in the front yard, plant the 16 in the garden. The constant bouquets you can gather all Summer long will make you think the arden is the place for Roses.

SET No.2.-For 50 cents, we select and send to any address, 8 istinct Ever-blooming Roses. This is big value fur $50 \mathrm{cts}$

SET No. 3.- For one dollar (SI), we select 9 Ever-blooming Roses and $4 \mathrm{H}$ ybrid Perpetual Roses, 13 different varieties in all, for $\mathrm{I}$

SET No. 4.-For 50 cents, we select 5 Ever-blooming Roses and Hvbrid Perpetual Roses, 7 different varieties in all, for $50 \mathrm{cts}$.

SET No, 5, For one d ollar (SI), we select o distinct Hirdy Hy brid Perpetual Roses. SET No. 6.-4 Hardy Hybrid Perperual Roses. 50 cts.

SET No. 7.-For one dollar (\$1), we select 6 Ever-blooming Roses, 3 New Roses, $x$ Moss Rose, I Polyantha Rose and 2 Hybrid Perpetual Roses, I3 different varieties in all, for $\$$.

SET N o. 8. - For 50 cents, we select 4 Ever-blooming Roses, New Rose, I Climbing Rose, I Polyantha Rose, 7 different varieties SET No. 9.-Fnr \$3, we will select, label and send to any address o Ever-blooming Roses. A grand collection for bedding or massing, only $\$ 3$.

\section{Chrysanthemums.}

The lovely Queen of Autumn is adding thousands to her subjects each season. No one who really loves fowers should be without at least a small collection of these asthetically beautiful flowers. We send out fine, strong plants that will be sure to give satisfaction. No

SE.T No. 10.-For one dollar (\$1), we send I 6 Chrysanthemums, I6 different - Farieties, all labeled

SET No. 11.-For 50 cents, we send 8 Chrysanthemums, in 8 different varieties, all labeled. This is one of our most popular collections.

\section{Ostrich Plume Set.}

SET No. 12.-Louis Boclzmer is now the most prominent of al the Ostrich Plume Chrysanthemums. With this remarkable novelty we place 6 other distinct and valuable Chrysanthemums-Harry $t$ Widener, grand yellow: Amber Gem, twisted petals, amber and old gold; Clara Rieman, rich lavender rose; Charity, gorgeous flowers, lurid crimson-5 prize-winners in all (complete descriptions, and picture of Lowis Boehmer, on page 16 ). Sent to any address for 70 offered for the money.

\section{Tuberoses at Low Prices.}

As Tuberoses have to be purchased fresh each season, close buyers will appreciate the following low prices for good blooming bulbs. We have larger bulbs at higher prices, but none are surer to blocm than

SET No. 13.-For 25 cents we send 6 Excelsior Pearl Tuberose SET. Big value for the money.

SET No. 14.- For 50 cents, we send ro Excelsior Pearl Tuberoses and 2 Orange Flowered Tuberoses, 12 bulbs in all, for $50 \mathrm{cts}$.

\section{Summer Flowering Bulbs.}

SET No. 15.-For 50 cents, we send a collection of ro fine named Gladiolus, all labeled.

SET No. 16.-For \$I, we will send a very choice collection of 10 amed Gladiolus, all labeled.

SET No. 17. - F or 25 cents, we will send 12 fine mixed Gladiolus. We make this unusual offer to introduce Gladiolus far and wide.

SET No. 19.-For 10 cents, we will send 3 named Gladiolus, Napoleon III, Ceres and Mad. Moneret.

\section{Star Collection of Seeds}

\section{For 1892,25 Cents.}

This collection goes better each season. We make it up finer than ever this year: think of it, to full-sized packets of lovely flowers of easiest cultivation, some of them Novelties; should any one be without flowers? The boys and girls-guess it would be fairer to put the girls first-are very partial to this collection.

\section{The Star Collection of 1892}

includes $I$ packet each of the following

- Pansy, Large Flowering-Very fine Mixed.

The Superb New Sharley Poppies. - Mixed Colors.

Sweet Peas.-A special mixiure for this Set.

Petunia, Superfine Mixed.- Home grown.

Salvia Splendens. - The well-known Scarlet Sage.

Chinese and Japanese Pinks.-Special Mixture.

Sweet Mignonette.-The great fazorite.

Balsams, Mixed Colors. - Our Camellia-fowered strain.

Cleome Pungens.-The novel honey-sweet plant.

Ipomeas, Mixed Varieties. $-A$ new effect in climbers. ro ft.

One packet of each of the above, 10 distinct varieties, mailid to any address, or added to any order, for 25 cents. 5 Sets for si II Sets for $\$ 2$.

SET No. 18 (The Little Folk's Set).-For 10 cents, we send i any address, or add to any order, a packet of nice Pansy Seed, a colors; a packet of Mixed Sweet Pers, and a packet of Sweet A, sum Little Gem. A little collection that will give lots of pretty flow ers all Summer with small care. Do not forget the little folks, 6 Sets for $50 \mathrm{cts}$.

\section{Our Quantity Collection of Flower} Seeds for 1892 .

Tie have named this set of 20 splen did varieties of annuals Quantity, as it certainly conveys the idea of a large quantity of good things for as it certainly conveys the idea of a large quantity of good things for fully and you will agree with us they will make a great show, and within tbe reach of all.

Pansy, Large Flowering.-Very fine Mixed.

The Superb New Shirley Poppies.-Mixed Colors.

Sweet Peas. - A special mixture for this Set.

Petunia, Superfine Mixed.-Home growur.

Salvia Splendens. - The well-knowun Scarlet Sage.

Chinese and Japanese Pinks. - Special mixture.

Sruet Mignonette- - The great favorite.

Balsams, Mixed Colors.- Our Camellia-fozvered strain.

Cleanze Pungens. - The honey-szueet plont.

Ipomeas, Mixed Varieties. - A new effect in climbers. Io fs.

New Inperial German Pansies. - Mixed.

Verbena Hybrida fine Nixed-All Colors.

Asters, All Varieties Mixed.-A choice Mixture.

Zinnia, Splendit Double Hired.-A fine selection.

Portulaca, Fine Mixed.-A popular strain.

Nasturtium, Fine Mixed.--Ton Thumb varieties.

Wild-flower Garden Seed.-A splendid assortment.

Mignonette, Erfurt.-Offered last year for the first time.

Siveet Alyssum Little Gem.-A beautiful pure white.

Poppy, Carnation Flowered.-Dowole flowers.

The entire Quantity Collection named above, 20 racke's in II, mailed to any address for $50 \mathrm{cts}$. Club Terms-5 Quantity Culiections for $\$ 2$.

\section{Red=Branched Hydrangea .}

This new and rare variety of Hydrangea is very desirable for culturc in pot box or tub, and a beautiful decorative plant for porches, walks, etc. being of a stately, robust habit of growth; leaves large, tbick and deep green, veins showing distinctly; beautıful dark-red colored branches, which its name implies, producing an atiraclive contrast from the deep green of the foliage; flowers beautiful clear pink, borne in immense panicles and produced in profusion during the Summer months. During Winter it can be safely stored in the cellar or similar place, secure from frost: fine plants. Price, $35 \mathrm{cts}$. each; 3 for \$I; larger size, $60 \mathrm{cLs}$. each ; 2 for $\$ 1$. 

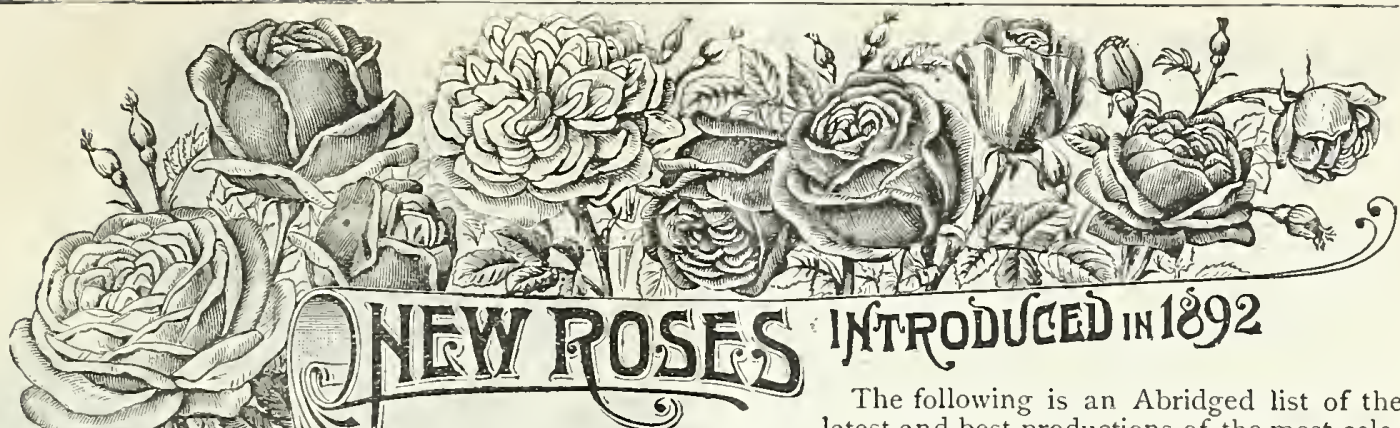

The following is an Abridged list of the latest and best productions of the most celeEty brated European Rose growers; they were imported by ourselves at large 12) expense and are now offered for the first time. The list is certainly of un markable beauty, which we have tried faintly to portray in our descriptions below. Besides being of vigorous growth and generous bloom these splendid varieties are recommended for the immense size of their buds and flowers, their superb and luxurious form, and their new and exquisite colorings combined with the most delicious fragrance, and as far as we can judge, some of them, at least, seem to mark a real advance in the possibilities of beautiful Roses. It will be noticed that several different classes are represented, all of which can be referred to under their proper heads in this book.

Madame Elie Lambert (New Tea Rose).-A wonderful, beautiful New Tea Rose. The colors are not particularly remarkable-scarcely unusual -and yet we have no hesitasion in recommending it as one of the most beautiful and valuable koses of which we have any knowledge. The flowers are extra large, fine globular form, very full and well built up. The French description says it is the absolute perfcction of form. The color is somewhat in the way of Madame de Watteville, but deeper; rich creamy white, faintly tinted vith pale golden yellow, and exquisitely bordered and shaded with solt rosy flesh; exceedingly beautiful and very sweet; petals large and of good substance; constant and profuse bloomer strong, vigorous and healthy grower-in short, a magnificent Rose in every way (see cut). $40 \mathrm{cts}$. each.

Charles de Franciosi (New Tea Rose).-This is a very pretty New Rose; fine, large, full form, very double and sweet, a good healthy grower and regular and very free bloomer; color rich creamy yellow or white, delicately tinged with salmon and fine peachy red; reverse of petals delicate salmon rose. to cts. each.

Christine de Noue (New Tea Rose). - This beautiful New Red Tea is a very charming Rose and promises to be one of the best of recent introductions. It is particularly valuable because red has been a very scarce color among Tca Roses, and this one seems exceptionally fine, lt is a splendid grower, making a large-sized graceful bush, with bright deep-green foliage; a constant and very free bloomer: the flowers are well borne up on strong stems, and are unusually large and handsome; the buds are long and finely pointed; and the color clear rich maroon or deep purplish red passing to lake, centre sometimes streaked with silvery white; the petals are finely imbricated, and the flowers are deliciously sweet. It is highly recommended as a valuable and every way desirable Rose. $40 \mathrm{cts}$. each.
Comtesse de Witzthum (New Tea Rose). - Extralarge, fine flowers, borne in great profusion; color pale canary yellow, very beautifi! It is a good healthy grower and we think will be a very satisfactory Rose for genera. planting. $40 \mathrm{cts}$. wach.

General Mertchansky (New Tea Rose).-This is a truly lovely Rose; the colo is exquisite rosy flesh, so sweet and tender, and clear and fresll, that it appeals to your affection at once, and you set it down immediately as a Rose you must have. It is of good large size, fine full form ; petals somewhat imbricated, very sweet; a good grower and constant bloomer. $40 \mathrm{cts}$. each.

Gustave Regis (New Climbing Hybrid Tea).-The Climbing Hybrid Teas are comparatively a new class of Roses not yet extensively disseminated, but worthy of trial in favorable situations. This one is pale canary yellowsometimes almost pure white -with just a tirge of gold the flowers are cup-shaped and semi-double, almost every one showing the centre very distinctly when fully open. It is richly scented and very fioriferous, and as the plant is evidently a strong healthy grower, it will doubtless nıake a charming climber where the Winters are not too severe. $40 \mathrm{cts}$, each.

Jaune $\mathrm{Nabonnand}$ (New Tea Rose). - It gives us real pleasure to offer this grand Rose; it is certainly one of the best of the year, probably one of the best in many years; grand in form and substance, a good grower and bloomer; grand and remarkable in color, which is solid rich chamoise yellow, centre sometimes delicately sliaded with coppery rose; very fragrant; a strong, vigorous and healthy grower. $40 \mathrm{cts}$, each.

Princesse Sarsina (New Tea Rose).--Fine fieshcolored Rose of good form and substance; base of petals finely tinged with apricot yellow, centre shaded rich peachy red; very pretty and desirable for general planting. $40 \mathrm{cts}$, each. 


\section{NEW ROSES INTRODUCED 1891.}

The Roses described below were introduced and offered for the first time in I89I. This year we are enabled to sell them at lower prices, and have placed them together for the convenience of customers, taking care to state the class to which each variety belongs. Many of them are exceedingly fine sorts, and all are worthy of careful trial.

Etoile d'Or (Star of Gold) (New Polyantha Rose).-This is an excellent New Polyantha Rose, one of the best and preltiest of all. The flowers are medium size, very fragrant, full round form, perfectly double, and borne in large clusters; color pale chrome vellow, with ric. citron red centre; ver striking and handsome, and entirely different from all other It is a neat, compact grower, begins to bloom quickly, and is usually loaded with flowers during the whole growing season. $25 \mathrm{cts}$, each.

Georges Farber (New Tea Rose).-Certainly a very charming Rose. Medium to large size flowers, somewhat irregular form, but full and well filled, and borne on long stems; color rich orange red, having a deep velvety gloss and changeable effect, very noticeable and distinct; a constant bloomer and very sweet. $25 \mathrm{cts}$. each.

Glorie des Cuivres (New Tea Rose). - A very lovely ever-blooming Tea Rose of grand and remarkable effect. The flowers are of elegant crown form, extra large, having petals full to the centre; the color is a rare and lustrous shade of salmon rose, delicately tinted with fine coppery gold. Buds are sometimes elegant citron red, with deep golden centre, a very novel and attractive color, quite remarkable; a constant bloomer and delightfully perfumed. $25 \mathrm{cts}$, each.

Jeanne Guillaumez (New Tea Rose).-Medium to large size, broad, thick, shell-like petals, well filled to the centre; color pale coppery yellow or old gold, beautifully toned with canary, and suffused with delicate blush; reverse of petals orange red. 25 cts. each.

Madame Adolphe de Tarle (New Tea Rose).-Medium to large size flowers, somewhat flat form, having an indented or ruffed outline, quite noticeable and pretty; color clear canary yellow, sometimes passing to white, tinted with sulphur yellow, and delicately shaded with rosy blush; highly perfumed. 25 cts. each.

Madame Olga (New Tea Rose).-Extra-large, deep, highly built-up flowers; good substance, large petals outside, becoming sinaller towards the centre, marked pineapple form; color rich creamy white, faintly tinged with pale canary yellow; delightfully scented, very handsome. $25 \mathrm{cts}$. each.

Madame Philippe Kuntz (New Tea Rose),--A lovely Rose, medium to large size flowers, clear bright pink or china rose, shaded carmine; reverse of petals silvery pink, centre elegantly shaded salmon yellow, sometimes flushed with crimson: flowers finely formed, very full and double, deliciously sweet, very pretty and attractive. $25 \mathrm{cts}$. each.

Madame Sadi Carnot (New Tea Rose).-Named in honor of the wife of the President of the French Republic. Blooms in large clusters; fine moderately full flowers, clear bright cherry red passing to magenta; makes pretty buds, and is delightfully perfumed. $25 \mathrm{cts}$. each.

Mrs. Jessie Fremont.-A seedling from Duchesse de Brabant, with not quite such large buds, but large, perfectly double flowers, well filled and handsome; color white, passing to deep rosy flesh, sometimes shaded with coppery red or old rose. 25 cts. each.

Maud Little.-Raised from Pierre St. Crr and Duchesse de Brabant; a very pretty Rose, of good form and substance, not entirely full, but very handsome and sweet; color soft china rose, with a peculiar glowing, lustrous bloom; very beautiful. $25 \mathrm{cts}$. each.

Souvenir de Francois Gaulain (New Tea Rose).This is an unusual and highly remarkable color for a Tea Rose, bright rich velvety crimson, very dark and exceedingly handsome, large full flowers, very fragrant; an early and constant bloomer. $25 \mathrm{cts}$, each.

Waban.-A valuable new Tea Rose, originated at the Waban Conservatories, Massachusetts, from whence it takes its name; it is a sport from that excellent old Rose, Catherine Nermet, and identical with it in every characteristic except color, which is a rich, deep bright pink, much brighter and more durable than Mermet, but has the same beauty of form, and is a more abundant bloomer; has proved very valuable for forcing under glass, and is believed equally good for open ground planting. $25 \mathrm{cts}$. each.

The Set of $x_{2}$ New Roses above, postpaid, for \$2.50.

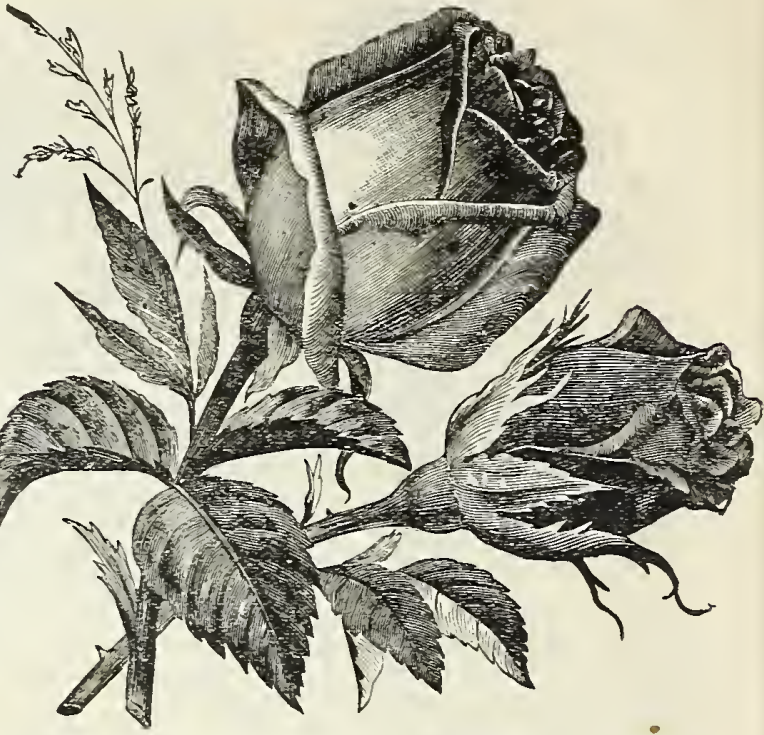

MAD. AGATHA NABONNAND.-COQUETTE DE LYON.

3 Beautiful Roses for 25 Cents.

\section{The Most Popular Rose Offer Ever Made.}

Last season we made the remarkable offer to send 3 choicest ever-blooming Roses to any address for only 25 cents. It was the best Rose advertisement we ever sent out, as thousands ordered it who never planted any Dingee-Conard Roses, and thousands of our regular customers ordered who wanted a few Roses to piece out, and knew a good thing when they saw it. All were delighted with the lovely varieties, which we could not afford to send for so little were it not for the enormous stock we had prepared and the advertising our Roses receive. Can be ordered separate by any one or added to any order. The varieties are as follows:

\section{Marie Lambert.}

Sometimes called White Hermosa, and is undoubtedly one of the very best; lovely white, occasionally tinged with blush; hardy and vigorous, and abundant sweet Roses all Summer long.

\section{Coquette de Lyon.}

This lovely Tea Rose is exquisite canary yellow color, clear translucent texture and delicious perfume; full and double flowers, borne in profusion.

\section{Mad. Agatha Nabonnand.}

This exquisite, beautiful variety is fair sea-shell tinted ros color; elegant buds and flowers; one of the finest.

Altogether you never saw anything like the above offer of 3 Roses for 25 cents. The choicest varieties, lovely white, tinted rose and clear canary; can be ordered separate or added to any order.

\section{For ro Cents Additional.}

$\mathrm{By}$ adding Io cents to the price of any set or combination offered on this sheet, or any order for plants, the purchaser is entitled to any one of the 4 grand varieties named as follows: First. The True Magnolia-Scented Moon Flower, superb for climbing, a sheet of bloom; a strong plant of this magnificent novelty, for Io cents added, will be appreciated. Second. Cuphea Llavæ, a lovely and distinct new plant, suitable for pots or baskets; a profusion of tricolored winged flowers, for Io cents added. Third. Achillea Alba, a splendid hardy perennial plant, trailing habit; masses of pure white flowers, for 10 cents added. Fourth. Lucullus.-This elegant China Rose is a vigorous grower and great bloomer; blood-red double flowers, for Io cents added. Any 2 of the varieties named, 20 cents; any 3 for 30 cents; the 4 for 40 cents. 


\section{EVER-BLOOMING TEA ROSES.}

\section{Standard List for General Planting.}

The Ever-blooming Teas are a very important class and among our most beautiful and valuable Roses for general planting; they begin to bloom almost as soon as planted, and continue throughout the whole season; they are noted for their exquisite delicacy of coloring, which includes the charming tea shades of yellow, fawn and cream ; also for their delightful fragrance, which surpasses that of all other Roses; they are not entirely hardy, and will not usually bear Northern Winters without shelter or careful protection; but some varieties are more hardy than others, and in favorable situations they often survive for many years, and many people keep them successfully by covering with leaves or brush, or by lifting and storing them in the cellar. It is from this class of Roses that we get all the best varieties for house culture and growing under glass; those particularly recommended for forcing for cut flowers are marked with an asterisk (*). The varieties described below are believed to be the best now known for general use; they are mostly strong, vigorous growers; constant and profuse bloomers; producing lovely buds and flowers of the most exquisite shades and surpassing sweetness; their first season's bloom more than repays their entire cost, and they are so easily and cheaply replaced, that if you can't keep them over, it pays to get them new every year; they are so exquisitely beautiful that no lover of Roses will willingly do without them.

Abbe Roustan.-A splendid Rose; large, full globular flowers, very double and sweet: color beautiful creamy white, elegantly shaded with rosy blush; sometimes tinged with purplish red. Io cts, each.

Aline Sisley.-A splendid Rose ; flower is large, very full and double, exceedingly sweet; color a rare shade of violet red, brightened with crimson maroon; makes elegant, large pointed buds; very beautiful. I 5 cts. each.

A merican Banner. White flowers, each bud and flower distinctly striped with bright red. I5 cts. each.

Andre Schwartz. True Tea Jacqueminot;" the color is brilliant, glowing scarlet, passing to rich crimson very bright and striking; a constant and profuse bloomer; flowers large, full and sweet. I5 cts. each.

Anna Oliver.-A superb Rose; very large, full form; very double and good substance color lovely, creamy blush, shaded with deep carmine, tinged and edged with silvery rose ; very fragrant. Ioc. each.

Aurore.-A very pretty and valuable Rose; full, medium size; very double and sweet; color silvery rose, beautifully shaded and veined with clear pink; a $n$ excellent bedding Rose. Io cts. each.

Bon Silene.- Noted for the great size and beauty of its buds which are valued very highly for bouquets and decorative

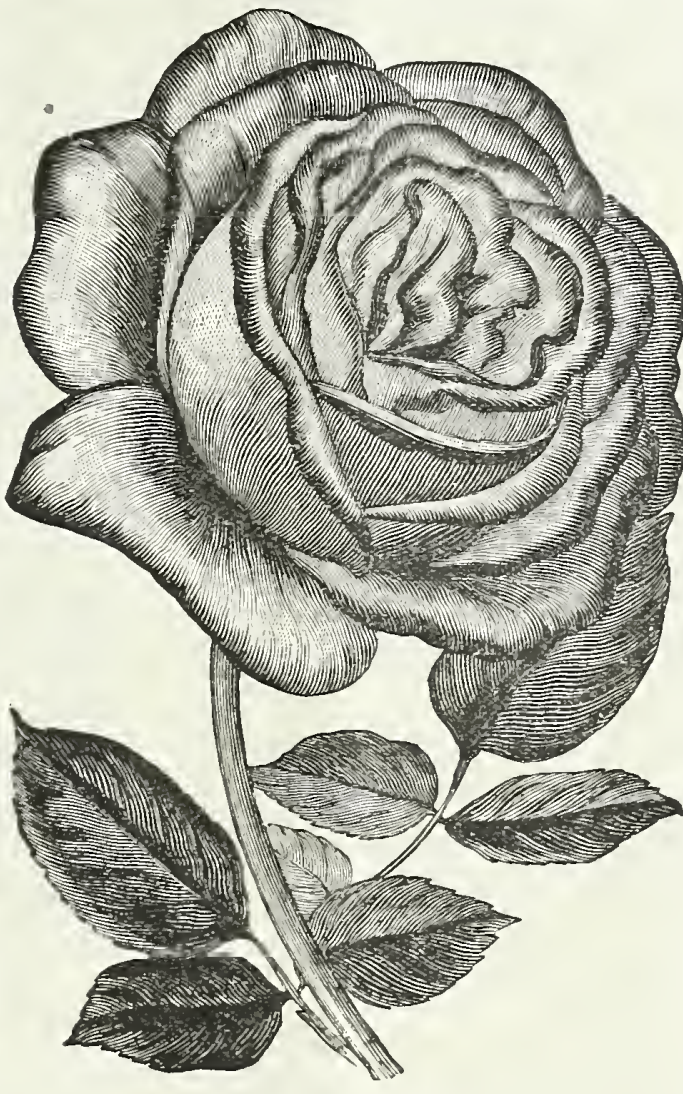

IAD, DE WATTEVILLE. celled for general planting; color fine chamois red, richly shaded with violet crimson; very sweet, and a constant bloomer; extrafine. I5c. each.

Charles Rovolli.-A charming Tea Rose; large, globular flowers, very full and double; delightfully fragrant color a lovely shade of brilliant carmine, changing to silver rose; centre and base of petals clear golden yellow. I $5 \mathrm{cts}$, each.

Comtesse de Caserta. Large, very beautiful flowers, fine full form, very double and fragrant; color dark purplish red, elegantly clouded with pale coppery yellow. Io cts. each.

Comtesse Riza du Parc.

-A fine variety, imported from France; color bright coppery rose, tinged and shaded with soft violet crimson; the flower is large, very fuil and sweet, and a profuse bloomer. I5c, each. Cornelia Cook.-This beautiful 'Tea Rose is in great demand for its magnificent buds, which are of immense size and of the most lovely and perfect form imaginable; color pure creamy white, sometimes faintly tinged with pale lemon and blush; very double. I5c. each. Devoniensis (Magnolia Rose).-Beautiful creamy white and rosy centre; large, full and double, delightfully sweet tea scent; one of the finest Roses. $15 \mathrm{cts}$. each.

Duchesse de Brabant.Soft, rosy pink, petals edged with silver; very sweet; one of the best. I5 cts. each.

Etoile de Lyon.-This magnificent Tea Rose is rich golden yellow, a strong, healthy and vigorous grower, immense bloomer, bearing flowers and buds all through the sea. son continuously, early and late; the flowers are of grand size, very deep, rich and full, excellent substance, exceedingly sweet; easily and surely one of the very best and most beautiful yellow Tea Roses for general planting ever introduced. Remarkablv hardy both as to heat and cold, frequently standing the Winters here uninjured in open ground without protection, and blooming nicely all through the hottest part of the Summer. I5 cts, each.

Francisca Kruger.-A strikingly handsome Rose, and one of the very best for open-ground culture, especially adapted for beds or masses; the splendid flowers are deeply shaded copper yellow in color; very large. $15 \mathrm{cts}$. each.

Mad. Etienne.-A strong, healthy grower; free and constant bloomer; handsome and desirable, Io rts, each. 
Madame Hoste.-Another season's trial has proved this grand Tea Rose very valuable and exceedingly beautiful; extra-large flowers and superb buds, very full and delightfully perfumed; color soft canary yellow, deepening at centre to pure golden yellow, beautifully flushed with pale amber; edges and reverse ot petals rich creamy white; has proved excellent both for garden and pot culture, and is particularly valuable for forcing for cut flowers. It is a good healthy grower, and blooms quickly and continuously both in open ground and house. $20 \mathrm{cts}$. each.

Mad. Joseph Schwarts.-A lovely Tea Rose; extra. large, globular flowers, very full and deliciously sweet; color pure white, èlegantly tinged and shaded with pale yellow and rosy blush; an exceedingly beautiful Ruse, and a constant and profuse bloomer. I5 $\mathrm{cts}$. each.

Mad. Lambard. - A first-class Rose for bedding; extra. large full flowers; very double and sweet; color a beautiful shade of rosy bronze, passing to salmon and fawn, beautifully shaded with carmine; an elegant Rose. I5 cts. each.

Mad. Margottin.-This is a grand Rose; always a favorite; very large, perfectly double; flowers elegantly perfumed; color beautiful dark citron yellow, with bright red centre; a strong grower and quite hardy. I5 cts. each.

Mad. Villermoz. - A lovely, creamy white rose, tinged and shaded with blush; extra-large size, very full and double; exceedingly sweet tea scent. Is cts. each.

Mad'elle Claudine Perreau.-Flowers are extra large and perfectly double; beautiful rosy flesh, passing to clear pink on white ground; rich crimson centre; a strong, vigorous grower and free bloomer; delightfully perfumed. I $5 \mathrm{cts}$. each.

Mad'elle Elizabeth de Gramont.-Beautiful bright carmine flowers, with crimson red centre; large, full and very weet; very striking and handsome. Io cts. each.

Marquise de Vivens.-A novel shade of rich violet crimson, with centre and base of petals creamy yellow, exquisitely tinted salmon and fawn; large, full flowers, very sweet, and a constant and profuse bloomer. $I_{5} \mathrm{cts}$, each.

Marie Ducher.- Rich transparent salmon, witl fawn centre; large size, very double and sweet. I5 cts. each.

Marie Guillot.-A splendid Rose, first class in every respect; color pure snow white, sometimes faintly tinged with pale yellow; extra-large size, full and double; very sweet tea scent. I5 cts. each.

Madame Pierre Guillot.-This is undoubtedly one of the finest and most beautiful New Tea Roses rccently introduced; large, full, globular flowers, having great depth and substance; color delicate orange yellow, distinctly veined and bordered with clear pink; altogether unique and remarkable, and exceedingly handsome; it makes fine, large, pointed buds, is a good healthy grower and a regular and constant bloomer promises to be valuable for forcing and conservatory, as well as for open-ground culture. $25 \mathrm{cts}$, each.

Madame Welche.-This grand Tea Rose still continues almost unsurpassed in beauty. The flowers have great depth and substance, and are of fine globular form, with broad thick petals and large, finely shaped buds; the color is a beautiful shade of soft amber yellow, deepening towards the centre to fine orange or coppery yellow, delicately tinged and clouded with pale ruddy crimson; both flowers and buds are remarkably sweet, and the plant is a good healthy grower, of compact bushy habit, producing its exquisite buds and flowers in great abundance during the whole growing season. It is excellent for conservatory, also for open ground planting, moderately hardy, but requires protection in Winter. I5

each.

Marie Van Houtte.-An exceedingly lovely Rose, not excelled by any; the flowers are extra large, very double and full, and deliciously tea scented; color pale canary yellow, passing to rich creamy white, elegantly shaded with pale rose; a constant and profuse bloomer. I 5 cts. each.

Marechal Robert.-Full globular flowers, long pointed buds, very double and deliciously sweet; color pure white, faintly tinged and shaded with soft blush and lemon yellow. 20 cts. each.

Mons. Furtado.-Bright sulphur yellow, good full form, fragrant; fine buds and flowers. Io cts. each.

Papa Gontier.-A splendid crimson Rose, one of the best for all purposes; indoors it makes immense buds and magnificent large bold flowers of great depth and substance; color rich cherry red, passing to clear glowing crimson; very fragrant and beautiful; a strong vigorous grower and constant bloomer; one of the very best and most valuable, both for open ground and greenhouse. I 5 cts. each.

President.--Very double and full; color soft rosy crimson, changing to brilliant carmine, shaded purplish red; very fragrant and beautiful, ${ }_{5} \mathrm{cts}$, each.
President Constant.-Extra fine, large regular form, well filled and delightfully perfumed; color clear rosy pink, finely shaded. I5 cts. each.

Princess de Radziwill.-Noted for long, finely formed conical buds and large, full, well-expanded flowers; the color is a rich dark crimson, shaded with bright coral red; delightfully scented and very handsome. I5 cts. each.

Princess de Sagan.-A Rose of great beauty; the color is fine rich velvety crimson, unusually handsome and attractive; it blooms quickly and abundantly, makes beautiful buds, and the flowers are borne on long stenis. I $5 \mathrm{cts}$. each.

Rubens.-Lovely pale yellow, slightly tinged with fawn; very double and sweet; large full flowers. I5 cts. each.

Regulus.-A splendid Rose; large perfect form, full and double, very fragrant; color brilliant carmine, with purple and red shading; extra good, both for house culture and open ground. Io cts. each.

Safrano.-Bright apricot yellow, changing to orange and fawn, sometimes tinted with rose; valued highly for its beautiful buds; very fragrant and one of the best. I $5 \mathrm{cts}$. each.

The Bride.-A superb, pure white Tea Rose; recommended as one of the best of its color; the buds and flowers are unusually large, finely formed, very double and full, and deliciously perfumed; it is a strong, healthy grower, and a quick and constant bloomer, does well in open ground, and is particularly valuable for growing in greenhouse for cut flowers, as it produces abundantly and its blooms are of the mostadesirable form and quality for floral work, bouquets, wreaths, etc. It is largely grown for this purpose, and usually sells well at good prices. The name, too, is very attractive, and almost every one who plants Roses wants one or more Brides. Grows and blooms well in Summer, but should be taken indoors in Winter. $20 \mathrm{cts}$. each ; 3 for $50 \mathrm{cts}$.; 6 for \$I.

Sappho.--Large, full and globular flowers, very handsome and distinct color; rich apricot yellow, delicately tinged with fawn and pale rose, delightfully tea scented; it is a strong, vigorous grower and remarkably free bloomer; the flowers are of excellent substance and last well. $20 \mathrm{cts}$. each.

Saint Joseph.-Flower very large, full and double, delightfully scented; color beautiful bright carmine, changing to salmon rose or light fawn. Io cts. each.

Sunset.-This grand Rose is a great favorite wherever known; the color is a rich golden amber or old gold, elegantly shaded with dark ruddy crimson, resembling the beautiful tints seen in a Summer sunset; the flowers and buds are extra large, full, finely formed and deliciously perfumed; it is a strong, vigorous grower and free bloomer, highly recommended both for open-ground and house culturc. $25 \mathrm{cts}$. each.

Suzanna Blanchet.-Color beautiful pale flesh, passing to silvery white, elegantly shaded with fine rosy amber; very tender and deliciously perfumed; large, finely pointed buds, medium size flowers, regular, full and handsome. I5 cts, each.

Sombrieul.-Pure white, edged and tinged with silvery rose; very sweet, large and double. I5 cts. each.

Souv. de Gabriel Drevet.-A rare shade of salmon-red, or terra cotta, delicately toned with violet crinson; flowers large and well filled; petals thick and of good substance, deliciously fragrant and very beautiful. I5 cts. each.

Souv. de Germain de Saint Pierre.-Flowers are borne in clusters; constant and profuse bloomer; color bright purplish crimson; very vivid; large, full and sweet. I5 cts. cach.

Souv. de Madame Pernet.--Large, bold flowers; fine full form, very double and sweet; color soft rosy crimson, tinged and shaded with clear yellow. I $5 \mathrm{cts}$. each.

Souv. de Victor Hugo.-A splendid Rose, introduced from France; color lovely citron red, with beautiful amber and fawn shading; large, tulip-shaped flowers, delightfully scented and a very free bloomer. I5 cts. each.

Souv. d'un Amie.-Extra-large, globular flowers; very full and deliciously sweet; color deep rosy flesh, beautifully shaded with rich carmine; edgcs and reverse of petals silver rose; vigorous grower and profuse bloomer. I5 cts. each.

Theresa Lambert. - Elegant and very handsome in form and color; delicate rose color, base of petals finely tinged with old gold, centre pale silvery salmon; vcry fragrant; large, very full and good. I5 cts. each.

Triumph de Luxembourg. - Immense rosy pink buds and flowers, perfectly double and exceedingly sweet; a vigorous grower and constant and profuse bloomer. $15 \mathrm{cts}$. each.

Valle de Chamounix.-A very beautiful Rose; good size; very double, full and sweet; color coppery yellow, elegantly shaded and tinged with rosy blush. I $5 \mathrm{cts}$. each.

SPECIAL OFFER. - The entire collection of 57 Everblooming Tea Roses, postpaid, for $\$ 5.50$, 


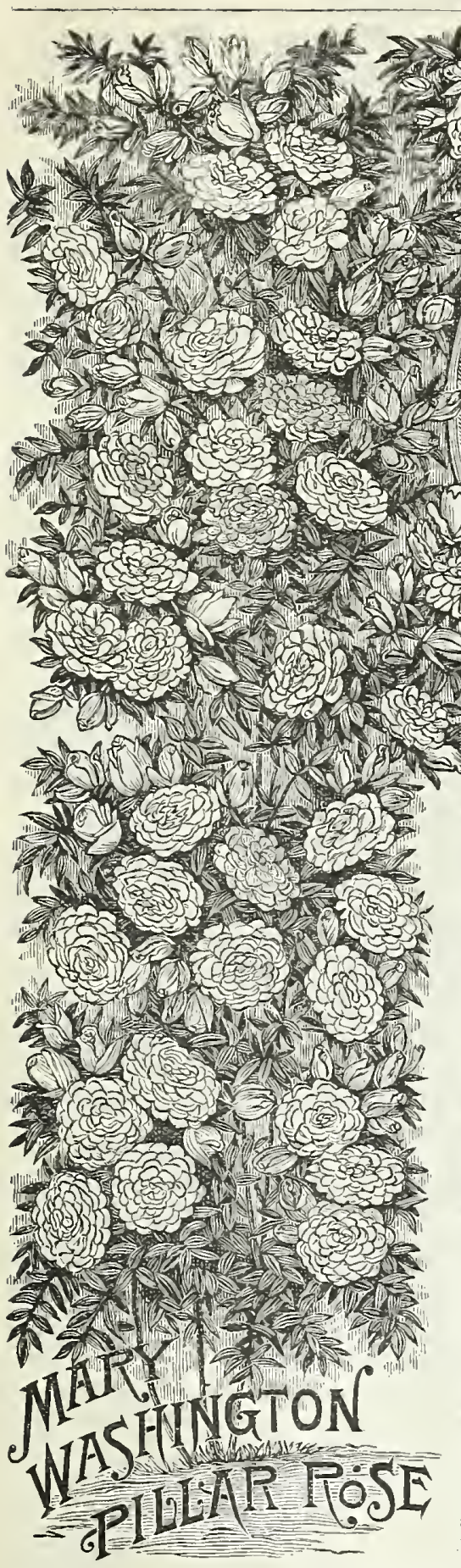

Ever=blooming Climbing Roses.

We recommend the 3 varieties below as best for Southern planters. Not hardy north of Washington. D.

Madame Alfred Carriere.-Extra-large, full flowers, very double and sweet; color rich creamy white, faintly tinged with pale yellow, exceedingly beautiful; a strong grower and most profuse bloomer; quite hardy. I5 cts. each. James Sprunt.-Deep cherry-red flowers, medium size, full, very double and sweet, a strong grower and profuse bloomer; moderately hardy. $15 \mathrm{cts}$. each.

Reine Marie Henriette.-Extra-large, finely formed flowers, very full and double, borne in clusters and richly tea scented; glowing crimson, elegantly shaded. I5 cts. each.

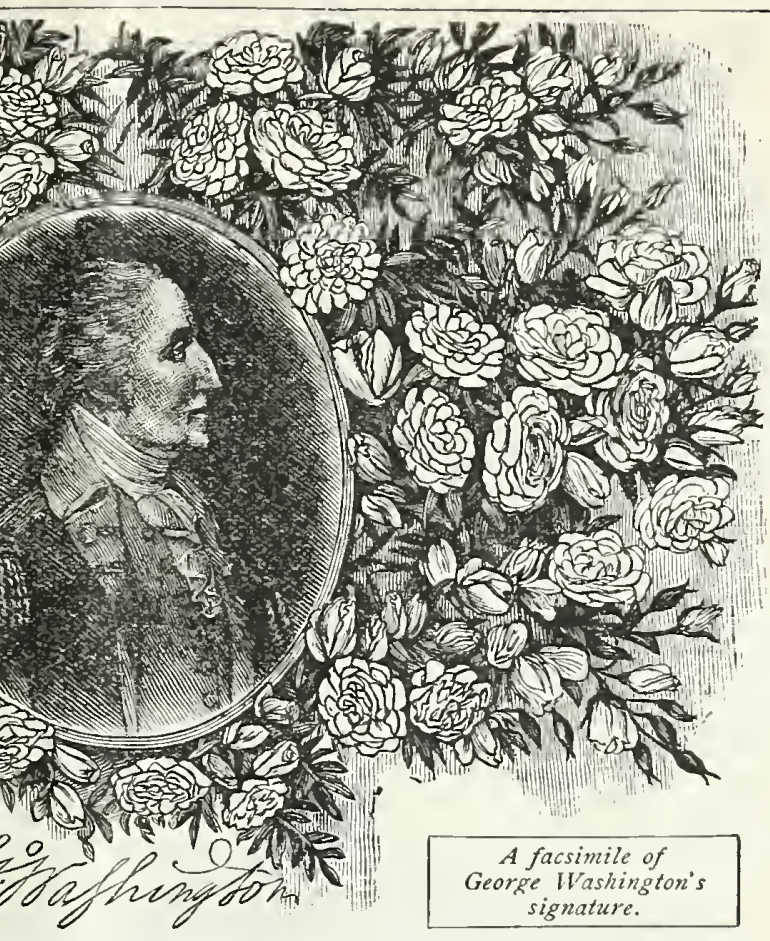

Mary Washington Pillar Rose

he public last year. The introducer gives the following interesting account origin and history: He says: "It is a historic fact that one hundred hat ever lived, raised in his garden at Mt. Vernon, a Seedling Rose, which proved to be a hardy perpetual-blooming climber, producing large, double Rose our first President took special delight, and named it after his mother, Mary Washington. The original bush can yet be seen growing in the It is a strange thing that this most valuable of all Roses has stood a hundred (t) public, yet it is Rose, the first and finest of its class, and raised and named by him ' who was first in peace, first in war, and first in the hearts of his countrymen. s, as the truest and best emblem of our remembrance and appreciation of greatness. We hope in time to see it trailing over the door or gateway nd named by George Washington, it is one of the most valuable sorts that been introduced for many years. A hardy perpetual-blooming climber in needed. Its fowers are of medium size, pure white, perfectly

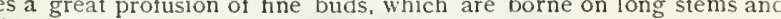
(fishoned musky flavor so much admired in olden times. Our stock is Our offer here of fine strong plants will therefore be
Ournom, housands in all parts of the country who would like some

\section{Hardy Climbing Roses.}

We recommend the 3 varieties below as best for Northern planters. Hardy north of Washington, D.C.

Baltimore Belle.-Pale blush, variegated, carmine, rose and white; very double; flowers in beautiful clusters, the whole plant appearing a perfect mass of bloom; one of the ery best climbing Roses. I5 cts. each.

Prairie Queen.-Clear, bright pink, sometimes with a white stripe; large, compact and globular, very double and full; blooms in clusters; one of the finest. $15 \mathrm{cts}$. each.

Pride of Washington. - Brilliant amaranth, shaded rose centre; large clusters; very double; fine. Io cts. each. 


\section{EVER-BLOOMING Bourbon AND CHINA Roses.}

As the Bourbon and China Roses have somewhat the same general characteristics, it seems most convenient to place them together. They are mostly vigorous, upright growers, free and continuous bloomers, and quite hardy both in regard to heat and cold. Some of them are among the hardiest Roses there are, and almost all are noted for the large size of their flowers, their full, regular form and brilliant colorings; also for their splendid Autumnal bloom, in which they surpass all other classes of Roses, not only in the number and beauty of the flowers produced at this season, but in their exquisite colors, which the cool days of Autumn seem to intensify in a remarkable degree; so that, considering their hardiness and vigorous growth, and almost entire freedom from the attacks of injurious insects, the large size, perfect form and brilliant coloring of their flowers, and their early and continuous bloom, extending through all the Summer and Autumn months, it is safe to say that the Bourbons and Chinas are among the very best and most desirable ever-blooming Roses we have. A tight covering of evergreen branches, forest leaves or garden litter put on in the beginning of Winter is usually all that is required to bring them through in good shape, unless in very cold localities.

Abbe Girardin.--Flowers very large and full, delightfully fragrant color bright satiny red, with rich crimson centre; constant and profuse bloomer. I5 cts. each.

Agrippina.-Brilliant fiery rcd, good size and form, very double, full and sweet; an early and profuse bloomer; much esteemed. I5 cts. each.

Archduc Charles.-Brilliant crimson scarlet, shaded with violet crimson; large, very double and sweet; a good hardy grower and constant bloomer; a splendid Rose. I5 cts. each.

Beau Carmine.-A splendid Rose for bedding; fine carmine red, very rich velvety color; flowers large, full and double; constant and profuse bloomer, fragrant and very desirable. Io cts, each.

Bourbon Queen.-A splendid Rose; large, fine form, very double, full and sweet; color bright carmine, changing o clear rose; petals edged with pure white. I5 cts. each.

Comtesse de Barbantane.-Clear flesh color, with deep crimson centre; large, full form, very double and fragrant; a noble Rose. I5 cts, each.

Douglas.-Dark cherry red, rich and velvety; large, full and fragrant; a neat compact grower and free bloomer. I5 cts, each.

Henry Plantier.-Color bright shining rose, extra large and full, very double and fragrant; hardy ; first class in every way. $15 \mathrm{cts}$. each.

Hermosa.-An excellent Rose, blooms in fine clusters; large, very double and fragrant; color beautiful clear rose; a constant bloomer, hardy, one of the best. I5 cts. each.

La Phœnix. - Fine brilliant red, shaded dark crimson; ood-sized flowers, full and double. Io cts. each.

Louis Philippe.-Rich dark velvety crimson, profuse bloomer, good form and substance, full and double, fragrant; an excellent bedding Rose. Io cts. cach.
Lucullus.-Beautiful dark crimson maroon, large, full and fragrant, very double, a constant and profuse bloomer; extra good for outdoor culture. Io cts. each.

Madame Bosanquet. - A fine old variety, niuch esteemed; pale flesh, shaded with deep rose; large size; very full and sweet. Io cts. each.

Mad. Eugene Beauharnais. - Fine clear red; a good constant bloomer, very pretty. Io cts. each.

Malmaison.-Rich creamy flesh, elegantly shaded clear peachy red, with rose centre; very large, perfectly double and exceedingly sweet; one of the finest and best Roses for outside planting; quite hardy. I5 cts. each.

Monthly Cabbage.-This fine old variety is still in great demand; the flowers are bright rosy pink, and remarkably full and fragrant; a constant bloomer; known also as the hundred-leaved Rose. $15 \mathrm{cts}$. each.

Pink Daily.-Clear bright pink, medium size, full and double; fragrant : a constant bloomer. Io cts. each.

President d'Oblecque.-Bright purplish crimson, large and double, fragrant, and a profuse bloomer. 1o cts. each.

Queen's Scarlet.-Very desirable and satisfactory; a constant and profuse bloomer : color rich velvety scarlet, very brilliant and striking; flowers large and quite full; strong hardy upright grower; excellent Rose for bedding, either in masses or mixed with other sorts. I5 cts. each.

Sanguinea.-Deep blood red, very bright, large size, double and somewhat fragrant; a constant and profuse bloomer; excellent for bedding. Io cts. each.

Viridifiora (Green Rose).-Flowers only moderately large, quite double; pure deep green; valuable only as a curiosity. I $5 \mathrm{cts}$. each.

SPECIAL OFFER.-The Set of 21 Bourbon and China Roses, postpaid, for $\$ 2$.

\section{The Polyantha or Fairy Roses.}

The Polyanthas are a lovely and distinct class of ever-blooming Roses, distinguished by their dwarf, bushy habit of growth, medium size and very double flowers, which are delightfully fragrant and are borne in large clusters and masses, frequently seeming to cover the whole plant with a sheet of bloom. They are good, vigorous growers and constant and most profuse bloomers, very pretty, and highly recommended for general planting, also for edges and borders to beds of the larger growing varieties. They are not entirely hardy, but will often survive the Winters in favorable situations, with usual protection.

\section{Clotilde Soupert.}

(The New Tea Polyantha.)-This lovely Rose comes from the Garden of Luxembourg, France. It belongs to the Polyantha class, but resembles the 'Tea Roses so closely that it is called a Tea Polyantha, and is undoubtedly the finest Rose of its class. The flowers are borne in clusters, and are of large, round, flat form, with beautifully imbricated petals; perfectly full and double, and deliciously sweet; color beautiful pinkish amber or pale creamy yellow, delicately flushed with silvery rose, sometimes ivory white, exquisitely tinted with pale salmon, and sometimes both red and white flowers are produced on the same plant. It is a particularly elegant and handsome Rose, always greatly admired. The bush is a vigorous and compact grower, and a continuous and remarkably profuse bloomer, being literally loaded with Roses throughout the whole growing season. It is highly recommended for bedding in open ground, and also for window and house culture; moderately hardy if given a good covering of leaves and litter before Winter begins. Be sure and include this lovely Rose with your order, $20 \mathrm{cts}$. each; 3 for $50 \mathrm{cts}$; 6 for $\$ 1$.
Flora.-A charming Polyantha Fairy Rose; the flowers are quite large, very full and round, delightfully perfumed and borne in immense clusters. The color is fine ivory white, delicately tinged with soft rosy blush. $20 \mathrm{cts}$. each.

George Pernet.- Very beautiful flowers, medium size, very full, with fine imbricated petals; lovely buff rose, delicately shaded lemon and fawn; extra fine. $15 \mathrm{cts}$, each.

Jeanne Drivon.-A lovely Rose, perfect, full form, very double and sweet; color pure white, faintly tinged with crimson; a distinct and valuable sort. I $5 \mathrm{cts}$. each.

Little Gem.-A very charming Fairy Rose; flowers of perfect form, very double and full; pure creamy white, sometimes delicately tinged with salmon rose. $15 \mathrm{cts}$. each.

Mad'elle Cecile Bruner.-Larger flowers than most of the others, perfectly double and delightfully fragrant; coior rosy pink, on rich creamy white ground; a great bloomer; very satisfactory for bedding. I5 cts. each.

Marie Pavie.-A very cheerful and elegant Rose, fine, round, compact flowers, medium size, very full and double, borne in large clusters and masses; excellent for cutting; color, rich creamy white, finely flushed with carmine rose : delightfully perfumed, very pretty and bright, and always in bloom. ro cts. each. Set of 7 Polyanthas, postpaid, \$r. 


\section{MYBRID TEA ROSES.}

The Hybrid Tea Roses are recommended for their constant bloom, brilliant colors and exquisite fragrance. Some varieties, such as La France, Duchess of Albany, Meteor, Pierre Guillot, Souvenir de Wootton, etc., are among our best and most satisfactory Roses for general planting indoors and out, but most of the others are of more tender growth, and therefore most suitabie for greenhouse culture and grow. ing in pots. They succeed moderately well in favorable situations in open ground, but are not very hardy and cannot be depended on to bear Northern Winters unless carefully protected, and in most cases had better be taken indoors when convenient before Winter sets in; their brilliant colors, profuse bloom and delicious sweetness make them particularly desirable for conservatory and house culture.

Antoine Verdier. - Large, beautiful flowers; bright| Growers of Waltham Cross. It resembles La France, but is glowing pink, beautifully shaded rich crimson, very full and sweet; immense bloomer; fine for bedding. I 5 cts. each.

Beauty of Stapleford.-Bright pink color, shaded carmine; large size, very full, perfect form; delightfully scented ; a constant and very free bloomer. Io cts. each.

Camoens.-Extra-large, full flowers; color china rose, suffused with pale yellow, passing to white, flushed with carmine; fragrant and fine. Io cts, each.

Countess of Pembroke.-Flowers large and of exquisite form, very full and sweet; color soft satiny pink, elegantly shaded violet red. $20 \mathrm{cts}$, each.

Duchess of Albany (or Red La France).-This is a superb new Rose recently introduced from England, where it originated with Messrs. William Paul \& Son, the great Rose more vigorous in growth and much deeper in color, hence the name, Red La France, seems very appropriate. It is a contnuous and very free bloomer, producing a great abundance of lovely buds and flowers all through the season. The flowers are extra large, elegant in form, very double and full, and remarkably fragrant; color brilliant rose pink, exquisitely shaded; it is highly recommended as one of the largest, sweetest and best Roses for general planting, both in open ground and for greenhouse culture; it belongs to the Hybrid Tea class, but is usually placed with the Hybrid Perpetuals, because it resembles them in form and habit of growth, etc.; it is reasonably hardy, but should have a good covering of leaves or straw before severe weather. $20 \mathrm{cts}$.

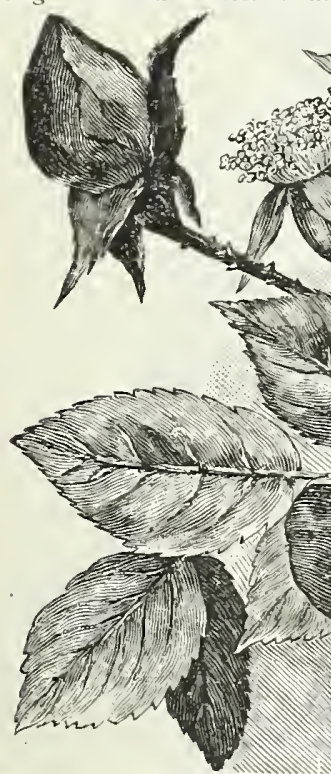

Docteur Reymont. This is at very elegant and handsome Hybrid Polyantha Rose, originated by one of the great Rose growers of Paris, and noted for being a hardy ever-bloomer, which is a very desirable class, that we do not have many of; it is a continuous bloomer, producing extra-large, very beautiful flowers, somewhat flat in form, but very full and regular, almost perfect shape; color bright, shining vermilion red; remarkably brilliant and striking; reverse of petals elegantly clouded with rich, violet crimson; exceedingly sweet and attractive, and excellent for open-ground planting; reasonably hardy, but requires covering in cold localities. $25 \mathrm{cts}$. each; 5 for $\$$ I.

La France.-Perhaps no Rose is better known or more highly valued for general planting, both in open ground or under glass, than La France. It is a Hybrid Tea, but usually classed with the Hybrid Perpetuals; it is exceedingly sweet and handsome, and altogether one of the loveliest and inost desirable Roses one can plant; both flowers and buds are of grand size; the color is a lovely shade of peach blossom, changing to amber rose, elegantly tinged with crimson; delicious tea fragrance; very full and wonderfully beautiful; commences to bloom soon after planting out, and continues until stopped by freezing weather. Moderately hardy, but requires protection in Winter. I 5 cts. each; 4 for $50 \mathrm{cts}$.; 8 for $\$ \mathrm{I}$. 


\section{Mardy Mybrid Perpetual Roses.}

The Hybrid Perpetuals are considered the most valuable of all Roses. They are distinguished by their vigorous, upright growth and large, bold flowers; and being entirely hardy, they are particularly valuable for planting in the Middle and Northern States. They also do well and are highly esteemed in the South. The flowers are very. large, frequently measuring five to six inches in diameter. They are exceedingly fragrant, and of the most gorgeous and dazzling colors, except yellow. Though called Perpetuals, very few are constant bloomers. Some varieties do not bloom until the second year, but when fully established they all bloom freely at the usual time early in the season, and some sorts continue to bloom at short intervals during the Summer and Autumn months. Being of vigorous and hardy growth, they will bear a good deal of hardship and neglect, and are sure to bloom every year without much trouble, but, like all valuable flowers, they are much improved in size and beauty by rich ground and good cultivation. They do very nicely set with shrubbery and other plants in borders, or in masses or beds in yard or lawn, and are highly valued and largely used wherever beautiful Roses are known. They should always be planted in open ground, as they are not suitable for house culture--the Tea Roses, Hybrid Teas and Polyanthas are best for this purpose. The Hybrid Perpetuals are considered among the hardiest of all Roses, and when fully established may be expected to bear ordinary Winters without injury, but, when convenient, a light covering of leaves, straw or evergreen branches, put on before freezing, is always an advantage.

Abel Carriere, - This grand Rose still ranks as one of the best; flowers are extra large, very double, full and sweet; color dark crimson, passin
handsome. I5 $\mathrm{cts}$. each.

Achille Gonod.-Brilliant purple carmine, large, full and sweet; a free bloomer. I5 cts, each.

Anna Alexieff.-A valuable variety. Extra-large size; very double and full, exceedingly sweet, and noted for its clear bright pink color. $20 \mathrm{cts}$, each.

Anna de Diesbach (Glory of Paris).-Brilliant crimson, sometimes shaded with bright maroon; long pointed buds, and large, finely formed, compast flowers, very full and sweet; very free bloomer. 20 cts. each.

Antoine Mouton. - This splendid Rose always gives satisfaction. The plant is vigorous and hardy, an early and free bloomer; the flowers are of extraordinary size and fullness: very fragrant; color bright clear pink; reverse of petals silvery

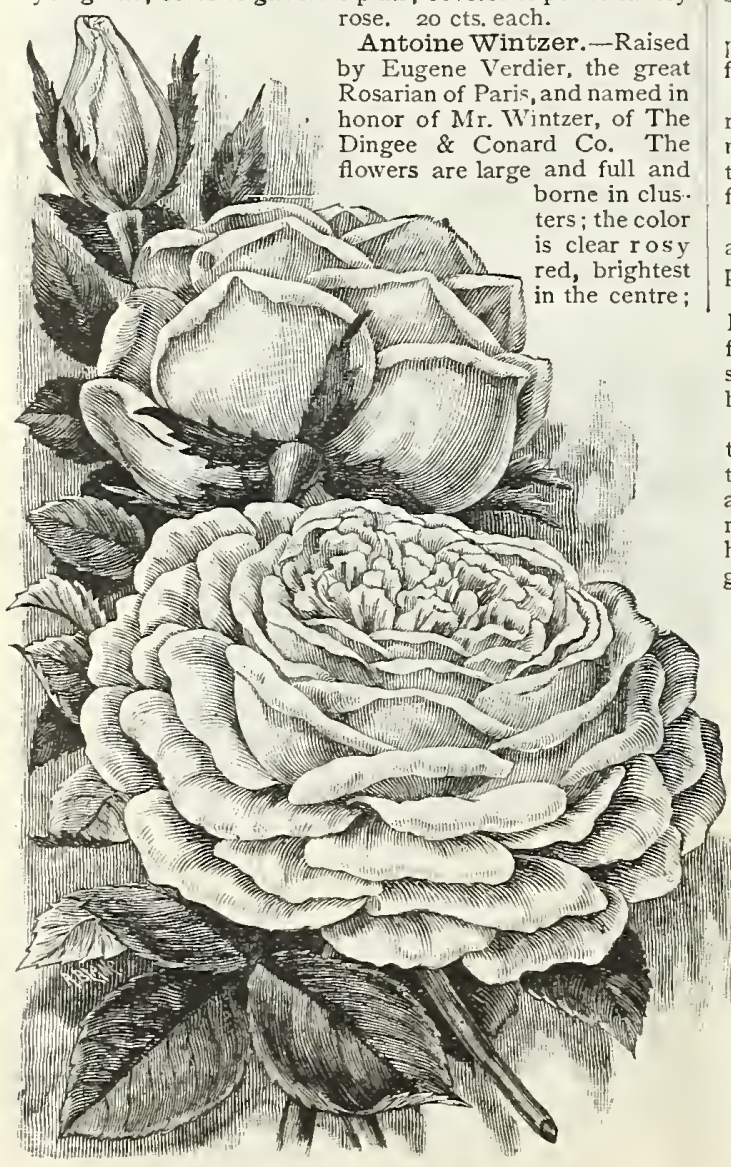

PERFECTION DES BLANCHES. it is a free bloomer and fragrant, recommended for general planting. $20 \mathrm{cts}$. each.

Captain Christy.-Extra-large, flat flowers, very full and regular; color a lovely shade of pale peach, deepening at centre to rosy crimson; very beautiful and valuable. I5 cts. each.

Caroline de Sansal._Clear brilliant rose, merging into rosy lilac, edged with bronze; very large and sweet; a firstclass variety. $15 \mathrm{cts}$. each.

Coquette des Alps.-One of the finest pure white hybrid perpetuals; large, full, finely formed flowers; color pure white, sometimes faintly tinged with pale blush; profuse bloomer, very hardy and beautiful. $20 \mathrm{cts}$. each.

Duchesse de Caylus.-First class for general planting : strong, hardy and vigorous, and a regular and free bloomer; extra-large flowers, fuil, perfect form, very fragrant; color rich cherry red, sometimes brilliant crimson, delicately tinged with scarlet; very fine. $20 \mathrm{cts}$. each.

François Levet.-A very beautiful Rose; soft china pink, delicately shaded carmine and blush; large, finely formed flowers; delight tfully fragrant; free bloomer. Ioc. each. General Jacqueminot.-Bright shining crimson, very ricls and velvety; exceedingly brilliant and handsome; makes magnificent buds, and is highly esteemed as one of the best and most desirable for open ground, and also for forcing. I5 cts, each.

Giant of Battles.-Brilliant crimson; large, very double and sweet; esteemed one of the finest old sorts for general planting. $15 \mathrm{cts}$. each.

John Hopper.-One of the most reliable and satisfactory Hybrid Perpetual Roses; flowers are large,very regular and full; color brilliant rose, changing to bright glowing pink, shaded with rich crimson; very sweet, and remarkably profuse bloomer. 20 cts. each.

Mad. Charles Wood.-A true perpetual bloomer; begins to bloom alnost as soon as planted, and continues all throngh the season; the flowers are extra large, very double and full, and quite fragrant; color bright fiery scarlet, passing to fine rosy crimson, elegantly shaded with maroon; very showy and handsome, and one of the best Roses ever introduced for general planting. $20 \mathrm{cts}$. each.

Mad. Thevenot.-An excellent Rose, rich crimson, passing to cardinal red, delicately tinged with violet; very showy and handsome; flowers large, finely formed, very double, full and sweet. I5 cts. each.

Leopold Premier.-Dark rich crimson; a fine large Rose, very full and sweet; free bloomer; very beautiful and valuable. $15 \mathrm{cts}$. each.

Mad.Plantier.-Pure white, large, very double flowers; most profuse bloomer, pcrfectly hardy ; suitable for cemetery and general planting. I5 cts. each.

Magna Charta.-A splendid Rose; extra-large, full flowers, very double and sweet; color clear rosy red, beautifully flushed with violet crimson; a sure bloomer, one of the hardiest and best for general planting. I5 cts. each.

Perfection des Blanches.--Large, pure white flowers, full and double; constant bloomer; very fine; one of the best perpetuals for general planting (see cut). I5 cts. each.

Paul Neyron.-We ask special attention to this grand Rose; the flowers are immense; it is probably the largest Rose grown, and one of the finest; bright shining pink, very clear and beautiful; very double and full, finely scented; blooms the first season and all Summer; no collection is complete without this magnificent variety. $20 \mathrm{cts}$, each.

Set of ar Hybrid Perpetual Roses, postpaid, \$3. 


\section{A Beautiful Novelty, New Striped Rose, Vick's Caprice.}

It is not often we can offer such a striking novelty in Roses as Vick's Caprice. Think of a large bush full of fine large red Roses having broad white stripes, as shown in the illustration. This grand variety is a true 1 ybrid Perpetual, being a sport from the splendid old Hybrid Perpetual Rose, Archduchcsse d'Autriche, and is therefore perfectly hardy, and can be grown by every one. The flowers are large, slightly cupshaped but full and deep; the petals are thick and lasting, having the ground color clear satiny pink, distinctly striped and dashed with white and bright carmine. It makes lovely, elegantsha ped buds, which show the stripes and markings to great advantage, and, being entirely unique and reinarkably beau. tiful, are very valuable for cutting and floral decoration, It is a vigorous, healthy grower, and blooms free ly at short itervals during the whole season. Besides bcing a valuable novelty, this is really a vcry handsome and attractive Rose which all can have and enjoy. $35 \mathrm{cts}$. each.

\section{Moss ROSES AND Perpetual Moss Roses.}

The Moss Rose is a strong, vigorous grower, perfectly hardy, and therefore justly esteemed as very desirable for outdoor culture in open ground. Most varieties bloom but once in the season, and usually not the first year, but the flowers and buds are very large and handsome; they remain in bloom a long time, and are highly prized wherever beautiful Roses are known. Moss Roses like rich ground and are much improved in beauty and fragrance by liberal manuring and good cultivation, but they bear hardship and neglect well, and always bloom profusely. They are suitable for planting with shrubbery and other plants in beds and borders, and also singly in lawn or dooryard.

Blanche Moreau (Perpetual). - This fine variety is highly recommended; flowers are produced in clusters, and are large, full and sweet; the color is pure white; both flowers and buds have an abundance of lovely deep green moss. $40 \mathrm{cts}$. cach. Captain Ingram. - Color brilliant carmine, very bright and attractive, medium size flowers, nicely mossed; a good bloomcr. $20 \mathrm{cts}$, each.

Comtess de Murinais.-One of the best and most satisfactory pure white Moss Roses; the buds are elegantly mossed; flowers large, full and fragrant; a valuable and very beautiful variety. $30 \mathrm{cts}$, each.

Elizabeth Rowe.-Extra-large, massive flowers, very double and well filled out; bright satiny pink, elegantly shaded; very fragrant and finely mossed. $20 \mathrm{cts}$. each.

Glory of Mosses.-A magnificent Moss Rose; extra large and perfectly double; color deep rosy carmine, shaded purplish crimson; very mossy and fragrant; one of the finest. $20 \mathrm{cts}$, each.

Henry Martin.-Rich glossy pink, elegantly tinged with crimson; large, globular flowers; very full and sweet, finely mossed. 20 cts. each.

James Veitch (Perpetual). - One of the finest perpetual Moss Roses; extra-large flowers, very fragrant and full; color

bright carnation red;

Luxembourg.-Color bright crimson scarlet, beautifully toned; large, deep, wcll built up flowers, with long, thick moss, delightfully perfumcd; very fine. $20 \mathrm{cts}$, each.

Madame Dupuy.-White, shaded with rosy llush

splendid large flowers; very double, sweet and fincly mossed. $20 \mathrm{cts}$. each.

Madame Rochlembert. - F'ine clear pink; cxtra-large,

fragrant flowers; full and globulic; nicely covcred with moss; a good standard solt. $20 \mathrm{cts}$. caclz.

Perpetual White Moss (Pipclual). - A true perpetual bloomer; one of the most mossy varicties; pretticst in bud; the flowers are of medium size, and bornc in large clusters ; fragrant, but not very double; color pure white. $50 \mathrm{cts}$. each. Princess Adelaide. - One of the bcst; extra-large
owers; very double and fragrant; buds beautifully mossed; color bright rosy pink; perfectly hard!: $20 \mathrm{cts}$. cach.

Purpurea Rubra.-Violet purple; large, full form, very double and fragrant; nicely covercd with fine moss; onc of the most satisfictory varieties for general planting. $20 \mathrm{cts}$. each.

Raphael.-Beautiful buds; very large and denscly covered with lovely moss; color pinkish white, shaded with rose; large, full and sweet; very distinct. $20 \mathrm{cts}$. each. 


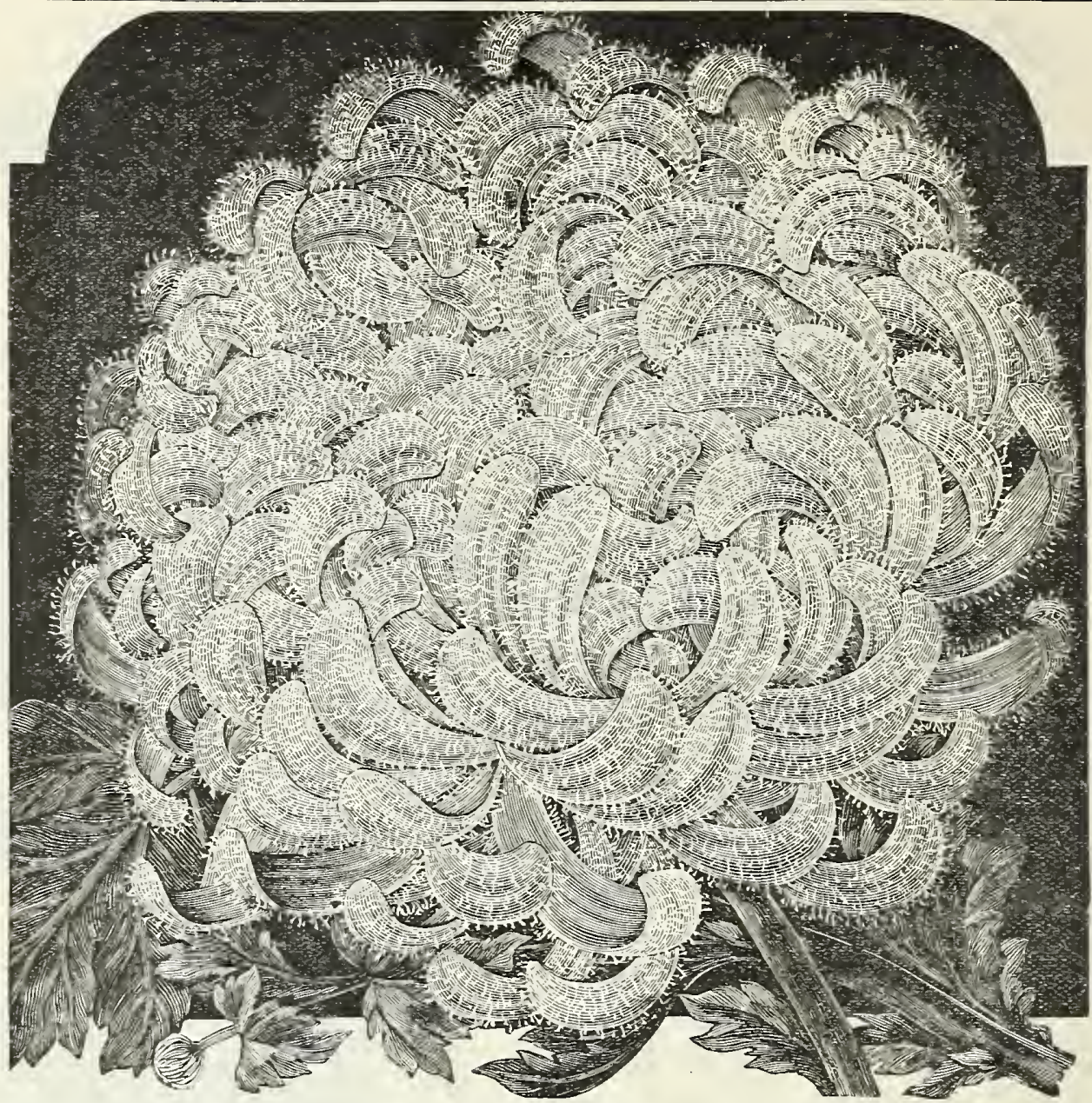

THE SPLENDID NEW PINK OSTRICH PLUME CHRYSANTHEMUM, LOUIS BOEHMER.

\section{Seven Lovely Chrysanthemums.}

The Famous Ostrich Plume Set.

Here are seven lovely Chrysanthemums, all choice sorts, including the wonderful Pink Ostrich Plume, Louis Boehmer, sold last year at $60 \mathrm{cts}$. each ; the famous White Ostrich Plume Chrysanthemum, Mad. Alpheus Hardy; Harry E. Widener, the grandest pure yellow Chrysanthemum of last year, and four other very choice sorts of charming and distinct colors. Seven in all, postpaid, for $\$ I$.

Louis Boehmer.-The splendid New Pink Ostrich Plume Chrysanthemum which created such a furore last year and sold at $60 \mathrm{cts}$. each. Grand flowers, extra-large size, splendid globular form; petals broad and lasting and thickly covered with the fine downy hairs so mucl admired, and from which the name Ostrich Plume is derived; color, deep rich pink; solid and fine. The plant is a remarkably strong and vigorous grower, blooms quickly and produces flowers in abundance all through the season. 25 cts. each.

Harry E. Widener.--This magnificent New Chrysanthemum was the winner of the Blanc prize, a beautiful silver cup, at the great Philadelphia Chrysanthemum Show, and is considered by many good judges to be the best yellow Chrysanthemum yet produced. Splendid flowers; extra-large, elegant, full form ; color, bright, clear lemon yellow, exceedingly beautiful and borne on long stout stems; one of the best for cut flowers, unequaled by any of the new sorts. $20 \mathrm{cts}$. each.

Mad. Alpheus Hardy.-The famous white Ostrich Plume Chrysanthemum which has attracted so much attention ; flowers exrra large and globular, with feathery plumelike petals, giving the appearance of great balls of pure white downy feathers; remarkably curious and handsome.
The illustration gives but a faint idea of its great beauty. A mber Gem. - This is another one of last year's splendid rovelties, and a very excellent variety; color, a beautiful shade of amber and old gold, flamed with orange red; flowers large and full, with curiously twisted petals twirled around the centre, making flowers like balls of yellow worsted yarn; grows vigorously, blooms quickly and well; excellent for general planting. $20 \mathrm{cts}$. each.

Clara Riemen.-New last year, and took Certificate of Merit at the great Indianapolis Show; color, rich lavender rose, with silver-white centre; extra-large, very handsome flowers, of good form and substance; is a healthy, vigorous grower; blooms early and abundantly; good for all purposes. $20 \mathrm{cts}$. each.

Garnet.-A very handsome and showy Japanese variety rich wine red, passing to silvery pink; large, full flowers, with curiously twisted petals, $20 \mathrm{cts}$. each.

Charity.- Splendid, large, luxuriantly perfumed flowers, very full and regular, sometimes six inches in diameter ; long, deep petals; bright carmine red, richly shaded lurid crimson; great bloomer; handsome and desirable. $20 \mathrm{cts}$. each.

Set of 7 for \$1; any 3 varieties, purchaser's choice, 50 cts. 


\section{Chrysanthemums.}

Sugar Loaf.-Noted for its vigorous growth and immense bloom; large, finely formed flowers, rich canary yellow, sometimes shaded bronze; took $\$ 50$ premium at Cincinnati Show, and one of six to win the \$roo at Indianapolis; highly recommended for open ground and does well everywhere. $30 \mathrm{cts}$. each.

Bartholdi.-Named in honor of $\mathrm{M}$. Bartholdi, the artist who designed the mighty Statue of Liberty in New York harbor; superb flowers, very regular form, clear carnation red. Io cts. each.

Chiffonier.-Silvery pink; petals turning and twisting towards the centre, forming a ball of perfect négligé. Io cts. each.

Rose Queen.-An early and profuse bloomer; extralarge, round, full flowers, measuring 4 to 5 inches across; petals curiously quilled for half their length and then flattened out; color, clear rosy amaranth, passing to rich pink; very bright and handsome; one of the best. $20 \mathrm{cts}$. each.

Frank Thompson.-Undoubtedly one of the most superb varieties recently introduced; grand flowers, with broad, thick petals and slightly incurved form, standing erect on stout stems; color, creamy white, delicately flushed with pale rose, and sometimes faintly tinged canary yellow ; truly magnificent in every way. 35 cts. each.

Bronze Jewell.-Extra-large, very full flowers; fine tubular petals; color, bright rich bronze. Io cts. each.

Duchesse.-Blooms in large clusters; large, full flowers : dark rich crimson, tipped with golden yellow. Io cts, each.

James R. Pitcher.-Fine, reflexed Japaneseflowers, very full and of great depth; color, light delicate blush, passing to pure white; highly perfumed, very sweet and entirely differcnt from the ordinary Chrysanthemum odor, $20 \mathrm{cts}$, each.

Mrs. Thomas Edison.-This is a splendid sort; immense flowers of splendid globular form, resembling great balls of fine, long, silky petals of the most delicate rose pink color; awarded a certificate of merit by the New Jersey Horticultural Society. $20 \mathrm{cts}$. each.

Hum-Ko.-A very beautiful variety from Japan; extralarge, splendid flowers: color, creamy white, beautifully shaded with bright pink and clear rose very beautiful. ro cts, each.

Zenobia.-Exceedingly large, double, Japanese-formed flowers: long, flat, drooping petals of purest snow white : very handsome and attractive. $20 \mathrm{cts}$, each.

Robert S. Brown.-Magnificent dark crimson flowers, immense size, splendid form; intensely bright and attractive, a good steady grower and profuse bloomer. $20 \mathrm{cts}$, each.

Molly Bawn.-Fine, large, solid flowers, borne in great masses and wreaths of bloom; pure snow white; one of the finest sorts, zo cts, each.

V. H. Hallock. - This grand Chrysanthemum should be much better known than it is, as it is really one of the largest and most distinct of the newer sorts; the flowers are immense, being frequently six inches across, and of splendid rounded form; color, a lovely shade of clear rosy pearl, with rich crimson centre; the petals have a rich waxy appearance and droop from the centre in the most graceful manner; the flowers are very durable and last for weeks, $20 \mathrm{cts}$, each.

The set of 14 Chrysanthemums above, postpaid, for \$2.10.

\section{New Hardy Perpetual Flowering Carnation Emperor.}

Believed to be one of the finest and most valuable of its class ever introduced. In flowers, foliage and fragrance it closely resembles the finest varieties of Carnations; it is a true perpetual bloomer, flowering constantly all through the season from June to December. The flowers are dark, rich crimson. elegantly fringed and delightfully clove scented. The plant is entirely hardy in all ordinary situations, needs no protection, and is sure to bloom continuously all through the season. It is largely planted by those who know its value. $20 \mathrm{cts}$. each; 2 for $40 \mathrm{cts}$; 5 for \$ $\mathrm{r}$.

New Hardy White Garden Pink-Snow.-A beall tiful pure white hardy Pink; profuse bloomer, large double flowers; very fragrant; neat, compact habit; fine for borders, edging, etc. $20 \mathrm{cts}$. each ; 3 for $50 \mathrm{cts}$.; I 2 for $\$ 2$.

Alba Fimbriata (White Fringed Pink). - A beautiful pure white garden Pink, elegantly fringed; clove scented; very double; blooms profusely; perfectly hardy; needs no protection in Winter; very pretty, compact habit; nice for edging or border. $20 \mathrm{cts}$. each; 3 for $50 \mathrm{cts}$; I2 for $\$ 2$.

The set of 3 hardy Garden Pinks for $50 \mathrm{cts}$.

\section{Carnations.}

New Carnation Pink, Golden Triumph.-This superb Carnation originated in Massachusetts, and is noted for its remarkable beauty and the very large size of its flowers, which average from $21 / 2$ to 3 inches in dia meter. The color is deep rich canary yellow, very handsome and attractive. The plant is a strong, stocky grower, of medium height, and a true perpetual bloomer, producing a great abundance of fine, perfect flowers all through the season. The flowers are borne on long stiff stems, and are deeply fringed and delicately clove scented. Sent out for the first time this season and in great demand. $40 \mathrm{cts}$, each.

Silver Spray.-This is a grand, pure white, early, freeflowering Carnation, of healthy, vigorous growth; makes fine bushy plants and bears an abundance of flowers on long stems; never bursts; petals finely fringed, and very fragrant; an excellent variety. I 5 cts. each.

Christmas.-This is a grand new Carnation; flowers are lovely and distinct shade of bright rose pink, finely fringed, very sweet, and borne on long stems; the plant is a strong, healthy grower, blooms quickly and continuously; undoubtedly the best of its color. I5 cts, each.

Hector.-A splendid new Carnation; intensely brilliant scarlet, brightest of all ; large, full flowers, borne in great profusion; delightfully perfumed; good hardy grower, immense bloomer. I5 cts. each.

Lamborn.-A splendid pure white Carnation; extra-large, full, perfect flowers; grows on long stems and unsurpassed by any in perfection of bloom; dwarf, compact grower, excellent for growing in pots or open ground. $15 \mathrm{cts}$. each.

Tidal Wave.-This is a very beautiful dwarf or lowgrowing variety, of a charming soft pink color; very productive and handsome; highly esteemed. I5 cts. each.

J. R. Freeman.-This is a grand Winter bloomer; color, rich cardinal crimson; remarkably striking and handsome, and delightfully clove scented; the plant is a strong, upright grower; flowers on long stems, full and double, elegantly fringed; does not burst; constant and profuse bloomer; one of the newest and best for all purposes. I 5 cts. each.

Lizzie McGowan.-We have pleasure in offering this splendid new Carnation, which is thought by some to be the finest pure white Pink cver introduced, and it is certainly a most lovely sort; color, pure paper white; petals crisp and lasting; close-jointed wiry stems, with vcry large, rcgularformed flowers, almost like Roses; a strong grower, very free flowering; valuable all the year around. I5 cts. each.

Chester Pride.-One of the very best variegated sorts: striped pink on white ground; very handsome and attractive; never bursts; free bloomer; good, healthy grower; very desirable. I 5 cts. each.

Nellie Lewis. - This is a grand new variety ; a very strong, vigorous grower; bears immense flowers of elegant form and quality: color, dark, rich pink, very beautiful and entirely distinct, clove scented, handsome and desirable. I5 cts. each.

Grace Wilder.--This beautiful sort is an early and free bloomer; flowers of delicate rose color, with exquisitely fringed petals and delicious fragrance. I5 cts. each.

New Carnation Pink, Golden Gate.-This is undoubtedly the finest pure yellow Carnation Pink yet produced. It is a seedling of Hinzey's White fertilızed with Field of Gold. The plant is a vigorous, healthy grower, of rather dwarf habit, blooms quickly and profusely all through the season; the color is pure golden yellow, without stripe or variation of any kind. The flowers are elegantly formed, very full and beautifully fringed, and quite fragrant. The best yellow for general planting. $20 \mathrm{cts}$, each.

The set of 12 Carnations above, postpaid, for \$ $\$$.50.

\section{Sweet May Pinks.}

These pretty Pinks are entirely hardy and of dwarf, compact growth, very suitable for edges and borders, cemetery planting, etc. 'The flowers are borne in great profusion, are perfectly double, clove scented and very sweet; the colors are mostly various shades of maroon, carmine and pink on hite grounds.

Laura Wilmore.-Dark crimson, white laced.

Prince Arthur.-White, rich maroon markings.

Alfred Harrington. - Rich maroon, marked white.

Pumila.-Scarlety maroon, whitc markings.

Juliet.-Cherry red, variegated pink and white.

Gertrude.-Rosy carmine, veined silvery white.

Price.-I2 cts, each; 3 for $30 \mathrm{cts}$.; set of 6 for $60 \mathrm{cts}$; $\$$ I per doz.; 25 for $\$ 2 ; 50$ for $\$ 4 ;$ I00 for $\$ 8$. 


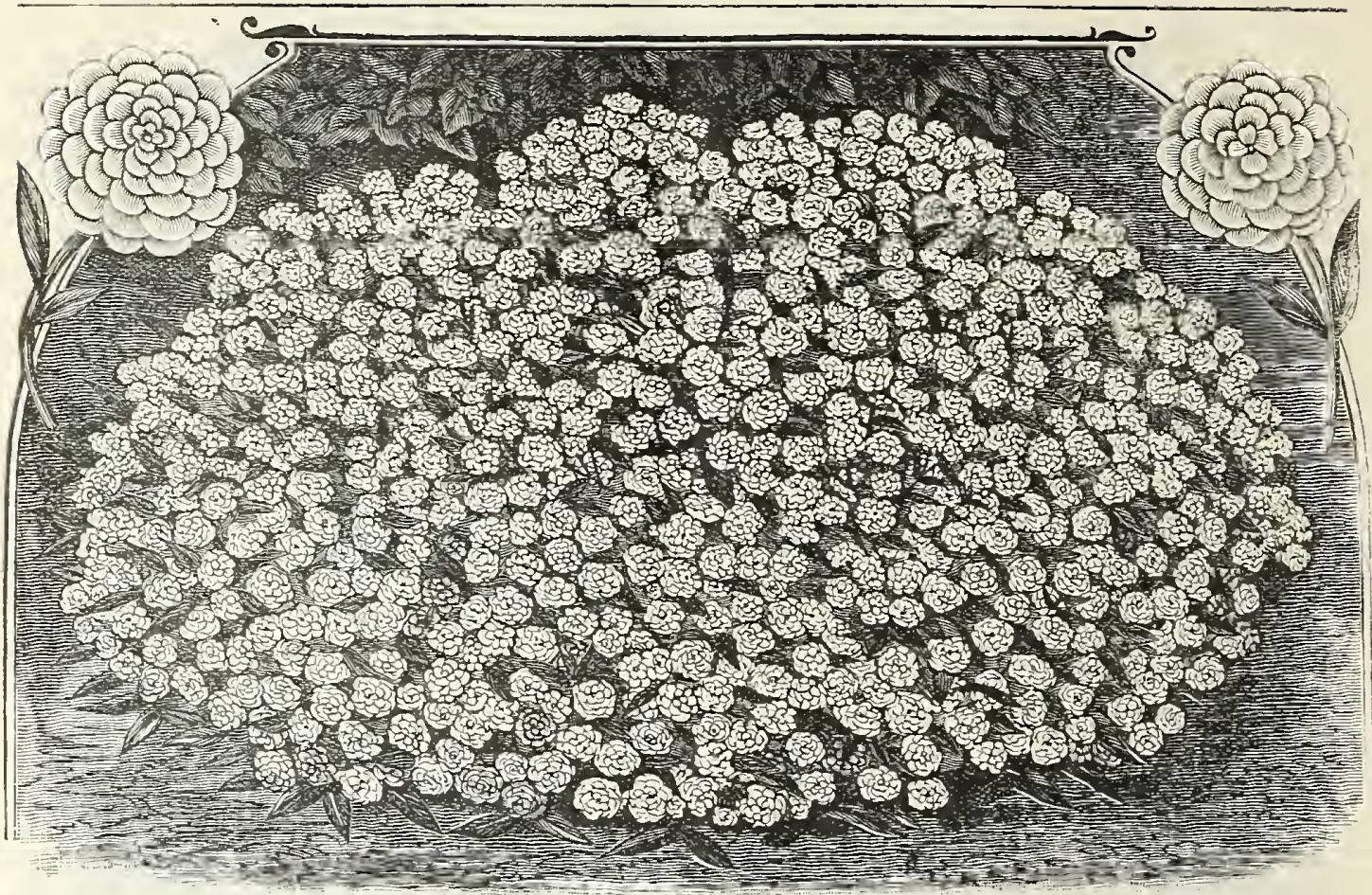

ACHELIA ALBA, FI. PI.

Solid Masses of Pure White Flowers.

Achelia Alba, Large Flowering, is now one of the most popular hardy plants. As will be seen by our illustration, the plants are of very compact habit, presenting a perfect mass of lovely white flowers. The blooming quality of this splendid novelty is something remarkable, flowering in will bloom three to five times as much . is entirely hardy and will last for years it is one of the most valuable snow-white flowers for cemetery planting; it will grow in any situation or soil, and is very valuable for planting amongst shrubflowers will grow. Price, I5 cts. each; 2 for 25 cts.; 5 for 50 cts.; I2 for \$I; \$8 per Ioo.

\section{HARDY PERENNIAL PHLOX.}

For hardy clumps of brilliantly colored masses of flowers on the lawn or among shrubbery, Hardy Perennial Phlox tak from Midsummer until checked by frost. The varieties offered freloware entirely hardy * will give great satisfaction.

Lothaire.-One of the most superb varieties ever intromasses of bloom of the most brilliant and gorgeous color, deep rich salmon, with intense crimson eye; wonderfully beautiful. Price, $25 \mathrm{cts}$, each.

Richard Wallace. - This very handsome, tall, showy variety forms large clumps, which are a conspicuous and permanent ornament to any grounds; great trusses of pearly most notable variety.

\section{PLATYCODON GRANDIFLORA.}

highly recommend this splendid New Plant from Japan. We can now supply fine strong roots that will flower the present season. This superb new variety is perfectly hardy, Plants grow about three feet high, and are covered all Summer with beautiful star-shaped, Gladiolus-like flowers. This new and charming flower will attract great attention; should be in every collection.
Platycodon Grandiflora Cœrulea. - Beautiful skyblue flowers. Large Two-year roots, $20 \mathrm{cts}$. each ; 3 for $50 \mathrm{cts}$. Platycodon Grandiflora Alba.-Lovely pearl-white flowers. Large Two-year roots, $20 \mathrm{cts}$. each ; 3 for $50 \mathrm{cts}$.

The two Platycodon, White and Blue, for 35 cents.

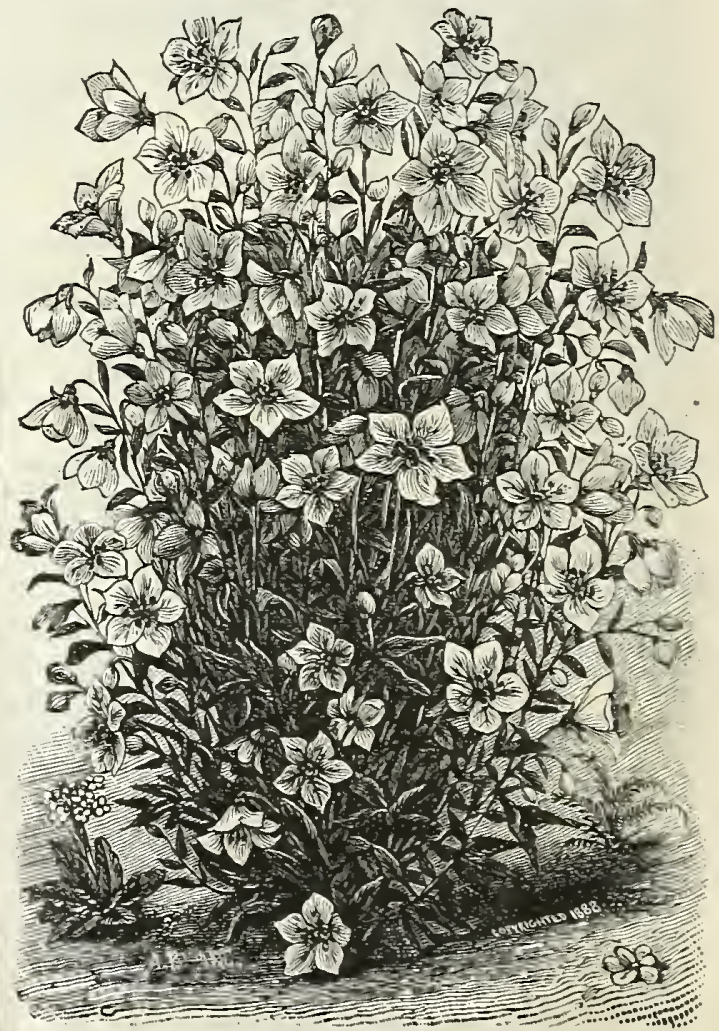

PLATYCODON GRANDIFLORA. 


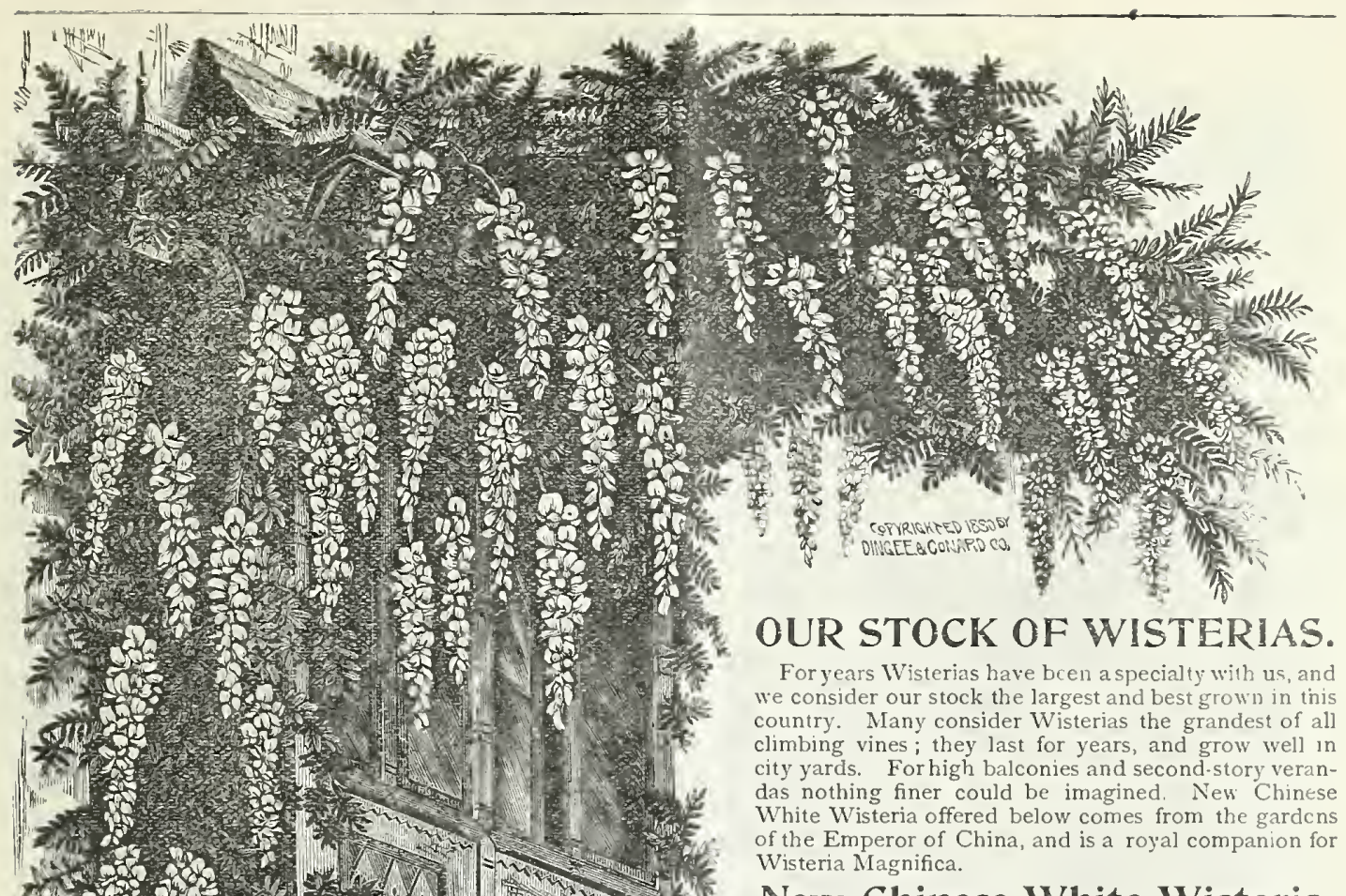

New Chinese White Wisteria.

In the balmy days of Spring, when leaves are pushing, grass springing, and buds and flowers blooming, what can be prettier than these grand Wisteria blooms, hanging in gorgeous clusters from porch, balcony and veranda railings; immense clusters of deliciously sweet and lovely flowers, great masses of blooms that you can gather by armfuls all around you? Nothing can be finer. Plant Wisterias whenever you want a good tall. growing vine to shelter hign porches or second-floor fronts. It grows strong and high, makes a pretty leafy screen, not too dense, and is loaded with bloom in the early Spring, just when you secm to need flowers and shade most. There are several varieties of Wisterias; this is the finest of all; immense clusters; pure white flowers, very sweet; extra-fine plants, grown in pots sure to bloom the first season. Price, 35 and 60 cts. each; latter should go by Express when convenient, or, if by Mail, must be cut back. The most beautiful effect is produced by planting the Now Chinese White, with either of the rich Violet Blues de. scribed below.

Chinese New Double Purple Wisteria.

We offered this magnificent new variety for the first time last season. It is entirely distinct, and the handsomest Wisteria now in cultivation; produces a profusion of splendid large racemes of double flowers, $c:-$
quisitely fragrant; color, deep shining purplc. Price, 7 quisitely frag

Chinese Blue Wisteria.-One of the most benutiful of all Wisterias; a vigorous, strong-growing vine, producing in early Summer a great profusion of large clusters of lovely, rich, violet-blue flowers, deliciously sweet and exceedingly handsome. One of the very best climbing vines for verandas, balconies, second-floor fronts,

New American White Wisteria.--A rare and elegant variety, contrasting finely with other sorts. Flowers are borne in shorter and more compact clusters than the Chinese varieties; pure snowy white and deliciously sweet; in this latitude blooms in early June. $35 \mathrm{cts}$, each; 3 for $\$$.

Wisteria Magnifica.

NEW CHINESE IVHITE WISTERIA.

Wisteria American Blue (Frutescens).

An elegant climbing vine, hardy and vigorous, and blooms later than the other varieties; pretty violet-purple flowers, borne in large clusters and very fragrant. $20 \mathrm{cts}$. each; 6 for $\$ 1$.
Similar to New Chinese White Wisteria, except in color, which is clear light blue, almost cerulean; a splendid and profuse bloomer, the fincst of its color in cultivation. $25 \mathrm{cts}$. each; 3 for 60 cts.; 5 for $\$$ I.

Special Offer.-The complete collection of 6 Grand Wisterias offered on this page for $\$ 2$, postpaid; or largest plants, by Express, 6 for $\$ 3$. 


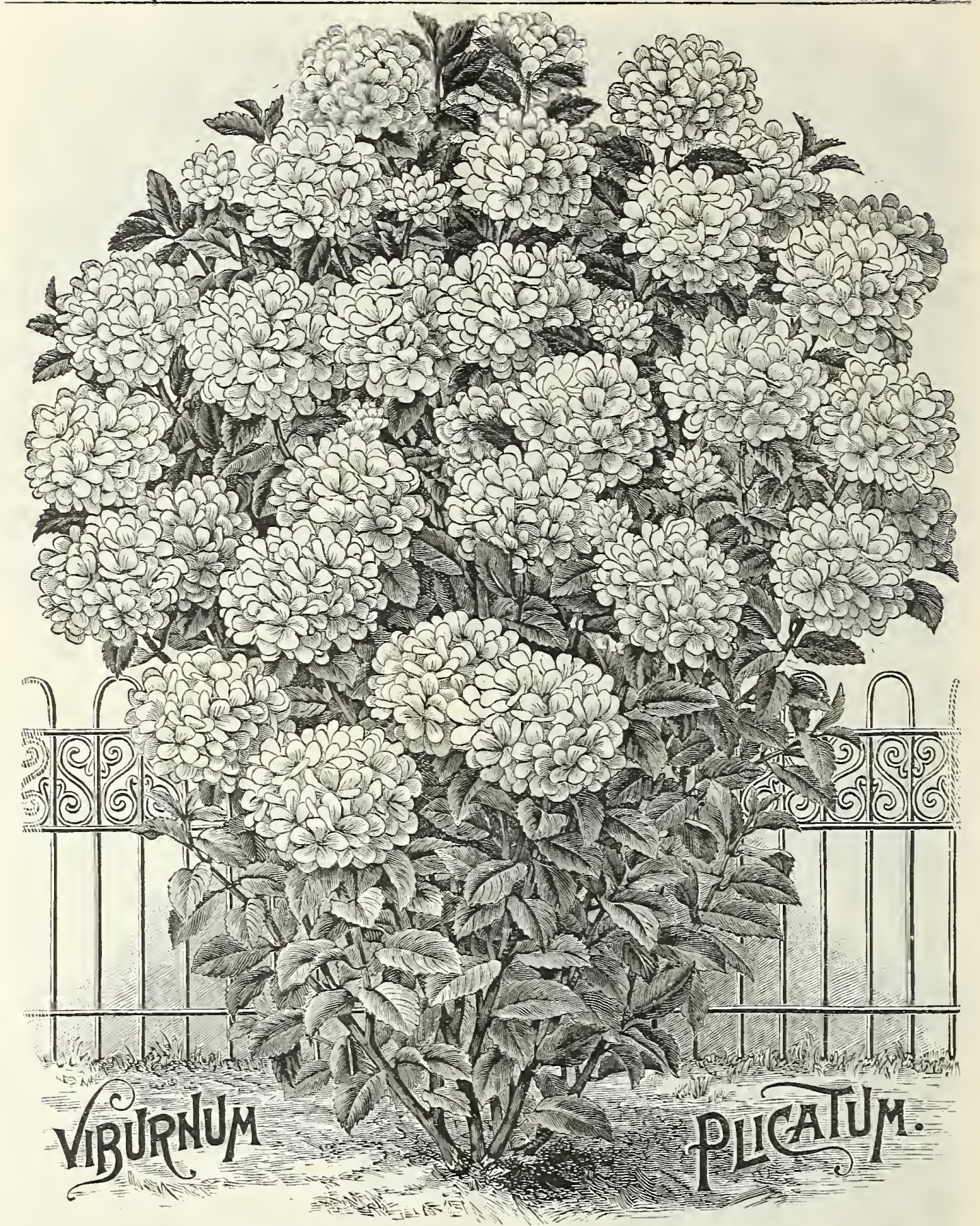

\section{New Double White Japan Snowball.}

This grand New Double White Japan Snowball is undoubtedly one of the most superb hardy flowering Shrubs ever introduced; it blooms in June when the whole bush is completely covered and loaded down with great compact balls of pure white double flowers like Miniature Roses. These magthey almost completely hide the leaves and branches, and the whole bush appears one dense mass of bloom; the tree is of erect bushy growth with deep glossy green leaves, having a peculiar crimped and crinkled appearance; grows 6 to 8 feet high, and is entirely hardy, needing no protection of any kind. We have grown it for a long time, but have only lately succeeded in raising a large stock; this year we hope to have enough for all, and our artist has made a fine illustration, which, though its wonderful beauty. We can cordially recommend it as one of the very best Hardy Ornamental Flowering Shrubs for dooryard, lawn, and park planting ; it is also very suitable for cemeteries, as it is vigorous and hardy, and sure to bloom, and being quite scarce and rare, it always attracts a great deal of attention wherever seen. It is one of the things you don ${ }^{\circ}$ want to miss getting, and ours is the true genuine variety, propagated from large old blooming plants here on our own grounds. Fine plants, 30 cents each; 4 for $\$ I$. 


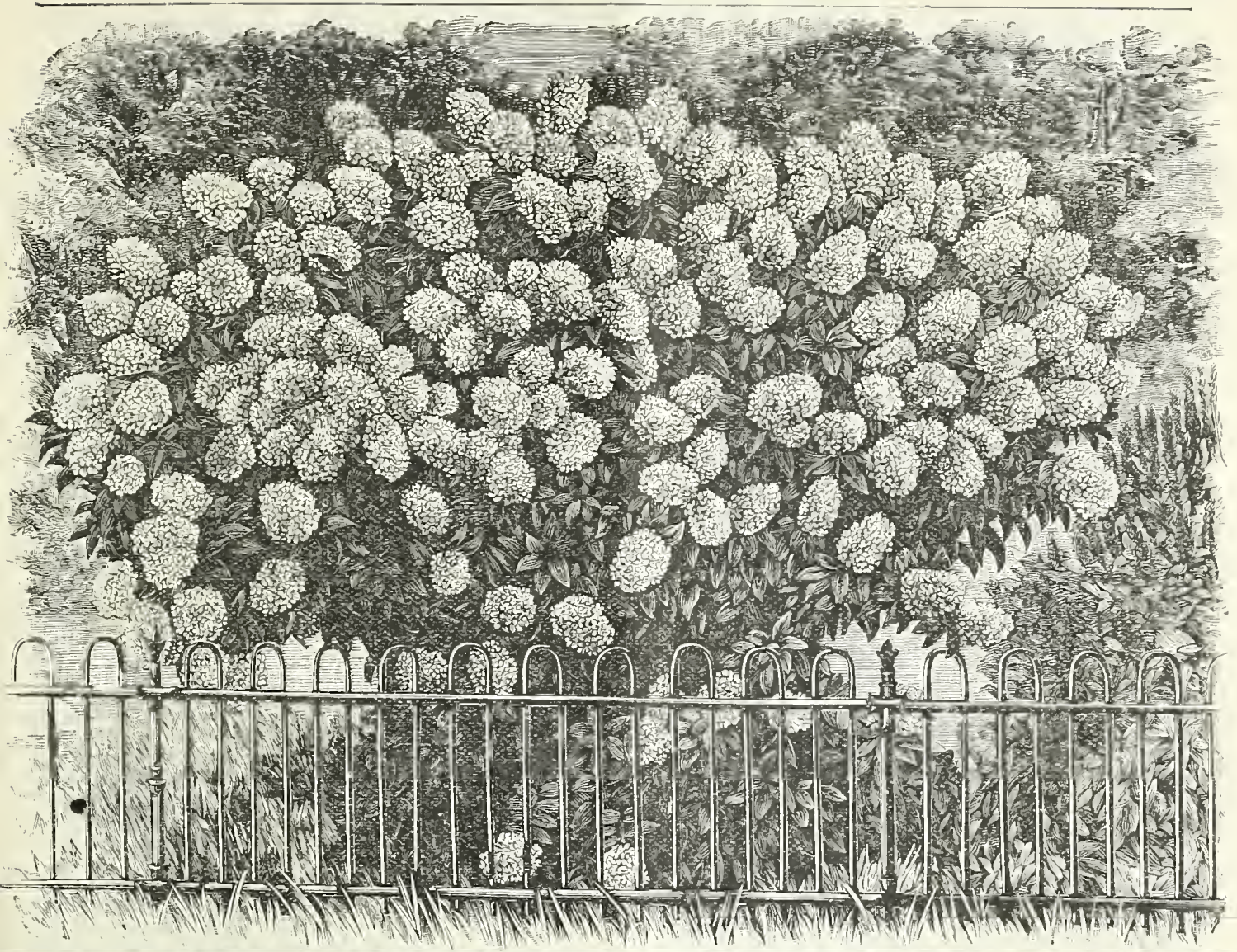

\section{Hydrangea Paniculata Grandiflora.}

The Hydrangea Panieulata Grandiflora continues to be one of the best and most handsome Hardy Ornamental Shrubs ever grown. It blooms finely the first year and gets better and grows larger with age; it grows 3 to 5 feet high, is perfectly hardy in all parts of the country and needs no protection in 1 Vinter; blooms in July and August, when other flowers are scarce, and remains in bloom for two or three months. The flowers are Pure White, afterwards changing to pink and rich coppery red, and are borne in immense pyramidal trusses, more than a foot long and nearly as much in diameter; as shown in the engraving, the plant is of compact and elegant habit, and when laden with its great masses of bloom is exceedingly striking and attractive. This noble Shrub is seen gracing alike with its superb presence, the cottage foreyard, large lawns, extensive grounds, parks and cemeteries. A universal favorite.

Treatment.-No special treatment is required; the Hydrangea will grow and thrive in all ordinary situations; the bush should be cut back every Spring, at least one-half of last season's growth, dug around and well manured. The finest flowers are borne on the new or young wood, and are largest and best when the plant has made a strong, vigorous growth.

STRONG ONE-YEAR PLANTS.-By Mail or Express, 20 and 30 cts. each; 2 for 40 and 50 cts.; $\$ 2$ and $\$ 2.75$ per doz.

STRONG TWO-YEAR PLANTS.-Cut back ready for planting, by Mail or Express, 40 and $60 \mathrm{cts}$. each 2 for 75 cts. and $\$$ I.IO; $\$ 4$ and $\$ 5$ per doz.

EXTRA-STRONG THREE-YEAR PIANTS.-Cut back ready for planting, by EXPRESS ONLY, \& I each ; 2 for $\$ 1.75$; 6 for $\$ 4.50$; $\$ 8$ per doz.

\section{The New Banner Althea.}

The New Banner Althea, or Rose of Sharon, originated here, and is probably the finest and most beautiful variety ever introduced. The flowers are as large as goodsized Roses, and very double; the color is pale rosy pink, elegantly striped with rich crimson, as shown in the engraving. It blooms in July and August, when every branch is loaded and crowded with flowers, the whole tree appearing a mass of brilliant bloom. It is a very handsome, erect-growing little Tree or tall Shrub; very desirable for dooryard, lawn or park planting; hardy in the ifiddle States. $35 \mathrm{cts}$, each; 2 for 60 cts.; $\$ 3.50$ per doz.

\section{New Hardy Orange.}

The New Hardy Orange is certainly a most remarkable and unexpected novelty for us to have growing vigorously here in the North; but it has now been fretty thoroughly tried, and has been found to do well and bear the Winter as far North as Boston, and perhaps further; it is a true Citrus, and has all the characteristics of the real Orange Tree. The tree is of dwarf symmetrical form, and is rather a slow grower until fully established; the flowers are lovely pure white, real orange blossoms, deliciously sweet; the leaves are thick and glossy, deep shining green, looking as if varnished, and of beautiful trifoliate form. $25 \mathrm{cts}$. each; 5 for $\$ I ;$ I2 for $\$ 2$. 


\section{Choice Mardy Shrubs and Plants.}

PLEASE NOTICE.-In this catalogue we offer only the leading varieties of Hardy Plants. As before stated, we make a great specialty of this. class, and can now supply ouer 100 different varieties, all of which are offered in the Unabridged Elition of $\boldsymbol{O} U \boldsymbol{R} \boldsymbol{N} \boldsymbol{E} \boldsymbol{W} \boldsymbol{G} \boldsymbol{I D E}$. If you have not a copy, and desire one, it is sent free on application.

\section{Hardy Shrubs.}

Althea, Blanche.-Flowers are much more perfect than the parent, the Double White Althea, being larger, of better substance and more double, while the color shows alınost pure white, the carmine threading at base of petals being hardly perceptible. $30 \mathrm{cts}$. each; larger size, $40 \mathrm{cts}$.

Althea, Variegated.-Half of each leaf is deep green, and half pure white; making an elegant contrast; flowers bright pink; large, very double and most desirable. I5 cts. each; larger size, $20 \mathrm{cts}$.

Berberis Thunbergii.-A new and handsome ornamental shrub, very desirable for lawn and garden; grows 3 to 4 feet high, regular, symmetrical forın; leaves beautiful, rich green, smali and perfectly shaped; flowers a delicate shade of coppery yellow, borne in great profusion, after which it is loaded with the most beautiful briliiant red berries; these remain on the bush late into the Winter, giving it a bright and pleasing appearance; entirely hardy. 25 cts. each; 3 for $60 \mathrm{cts}$.

Calycanthus, Florida.-This beautiful sweet-scented shrub is very widely known; flowers purple, quite double and borne in profusion during the entire season. Is $\mathrm{cts}$. each; larger size, 20 cts.

Deutzia Crenata.-Strong, stately grower; attains the height of 4 to 6 feet; flowers white, tinged pink on outside of petals; very double and full; borne in the greatest profusion during $\mathrm{J}$ une. I $5 \mathrm{cts}$. each; larger size, $20 \mathrm{cts}$.

Deutzia, Pride of Rochester.-Resembles Crenata, except that the flowers are pure white, with a faint shade of rose on outside of petals. I5 cts. each; larger size, $20 \mathrm{cts}$.

Deutzia Gracilis.-Dwarf, compact form, not exceeding 2 to $21 / 2$ feet in height; flowers pure white, beli-shaped branches gracefully drooping, loaded with magnificent snowwhite bells. I $5 \mathrm{cts}$, each; larger size, $20 \mathrm{cts}$.

Hibiscus. - The flowers are produced in great profusion they are somewhat cup-shaped and of immense size, frequently measuring 6 to 8 inches in diameter; the colors range from pure white through all shades of blush and pink to bright rosy crimson. They bloom during July and August, and continue in bloom along time; forms large clumps, 3 to 4 feet high, and nearly as wide. Strong roots, $20 \mathrm{cts}$. each; 3 for $50 \mathrm{cts}$.

Lilac, New Persian.- This grand new Lilac blooms in early June; flowers beautiful deep purple, and borne in profusion, hanging in the most graceful and lovely loose panicles; is truly a rare sight wherever grown; flowers very fragrant, filling the air with its delicions aroma; leaves rich, dark green, rather small and delicately shaded; habit of growth very neat, compact and perfectly hardy in any locality; one of the most desirable of flowering shrubs, 20 cts. each; larger size,

Mock Orange, Syringa.-A rapid-growing, medium(vith very fragrant white flowers, $20 \mathrm{cts}$. each. Spirea Callosa Rubra.-A fine, bushy, compact shruo growing 3 to 4 feet high, bearing a profusion of deep rosy red flowers in large flat clusters or panicles. I 5 cts. each; larger ize, $20 \mathrm{cts}$

Spirea Prunifolia (Bridal Wreath).-Very beautiful; flowers pure white and perfectly double, like little Daisies. $5 \mathrm{cts}$. each ; larger size, $20 \mathrm{cts}$

Spirea, Van Houtti.- The bushes form fine, compact clumps, about as broad as they are high; generally 4 or 5 feet; the purc white flowers are borne in such masses that they form great plumes; which the long, slender branches allow to droop gracefuily, $20 \mathrm{cts}$, each.

Weigela Rosea.-The flowers are large and of a deep rosy color; they are borne in such profusion that the whole plant appears a mass of lovely bloom. I5 cts. each; larger size, $20 \mathrm{cts}$.

Weigela Candida.-New and fine; pure snow white flowrs, borne in great profusion. I $5 \mathrm{cts}$. each ; larger size, $20 \mathrm{cts}$.

Yucca Filamentosa.- The flower stalk is from 2 to 4 feet high, and rises from the centre; it bears a profusion of creamy white bell-shaped flowers; very beautiful. I5 cts. each; ; larger size, 20 cts.
Hardy Climbing Vines.

Ampelopsis Veitchii, Boston Ivy.-A new and very beautiful hardy climbing vine, now extensively used on the finest suburban residences, churches, etc.; also in parks, lawns and cemeteries, lt is a hardy and quite rapid grower; clings fast to stone, brick or wooden walls without support; droops with inimitable grace from porches, balconies, and cornices, covering all in Summer with a mantle of lovely green foliage, which changes as Autumn approaches to brilliant crimson. I5 cts. each ; 8 for $\$ I$; larger size, $20 \mathrm{cts}$. each; 6 for $\$ I$.

Akebia Quinata-Japan Akebia.-A new twining climber, suitable for pillar or trellis; handsome and distinct foliage, and chocolate-colored, fragrant flowers; very desirable, I5 cts. each; larger size, $20 \mathrm{cts}$.

Bignonia Grandillora - Trumpet Creeper. - A hardy, fast ${ }^{\circ}$ grower, suitable for covering dead walls, back buildings, fences, etc.; produces in August large, orange-red, trumpet-shaped flowers in clusters, as shown in illustration. I 5 cts. each ; larger size, $20 \mathrm{cts}$.

Chinese Sweet-Scented Honeysuckle. - A fine variety, of vigorous growth; white and yellow flowers; a very fragiant and constant bloomer. I $_{5} \mathrm{cts}$. each; larger size, 20 cts.

Evergreen Sweet,-scented Honeysuckle.-A hardy vigorous grower; blooms nearly all the season; deliciously fragrant; flowers buff, yellow and white; very desirable for veranda and trellis work. I5 cts. each; larger size, $20 \mathrm{cts.}$

European Sweet-Scented (Belgian i Honeysuckle. -A fine, hardy grower; flowers large and exceedingly color buff yellow and red; a constant bloomer; one of the finest Honeysuckles; suitable for trellis or pillar. I5 cts. each; larger size, $20 \mathrm{cts}$.

Golden-Leaved Honeysuckle. - An elegant and very desirable variety of moderate growth; leaves beautifully reined and netted with clear yellow, so that ihe pre vailing color of the foliage is bright yellow; flowers yeilow and fragrant; admirable for pillar and trellis work. This beautiful Honeysuckle is so distinct that it is one of the best varieties to plant with other vines for a striking contrast. I5 cts. each; larger size, zo cts.

New Halliana Honeysuckle.-A new variety introduced from Japan, and considered a great acquisition; it is evergreen and a constant bloomer; flowers pure white changing to yellow : very fragraut; good for trellis or pillar; one of the very best varieties for all purposes. I5 $\mathrm{cts}$, each; larger size, $20 \mathrm{cts}$.

Red Coral Honeysuclkle.-A hardy, rapid grower, suitable for rock-work, etc.; bright red, trumpet-shaped flowers. $15 \mathrm{cts}$. each; larger size, $20 \mathrm{cts}$.

Set of a Hardy Climbing Vines offercd above for \$\$.25; Largest, $\$ r .70$.

\section{Ornamental Grasses.}

Eulalia Japonica Zebrina.-This beautiful ornamental grass is one of the finest plants for lawns. It grows 4 to 5 feet high, is perfectly hardy, needs no protection, and improves with age. The leaves are deep green, STRIPED CROSSWISE WITH BROAI BARS OF PURE WHITE. Our plants are propagated from the root, and therefore more valuable than cheap seedlings which do not come true. Strong plants, $25 \mathrm{cts}$. each; 2 for $40 \mathrm{cts}$; $\$ 2.25$ per doz.

Eulalia Japonica Variegata.-An older variety than Zebrina, but equally valuable; LEATES STRIPED LENGTHIVISE; FINE CREAMY WHITE AND BRIGHT GREEN. The plumes of both the Eulalias make pretty parlor ornaments. $25 \mathrm{cts}$. each; 2 for $40 \mathrm{c}$. ; $\$ 2.25$ per doz.

Erianthus Ravenna.-A perfectly hardy ORNAMENTAL GRASS, throwing up splendid flower stalks, 8 to xo feet high, the first season. It bears beautiful feather-like pluines, highls: valued for parlor ornaments; it is a striking and handsome lawn plant. $20 \mathrm{cts}$, each; $\$ 2$ per doz.

SPECIAL OFFER.-We will send the two Eulalias ani one Erianthus-3 for $60 \mathrm{cts}$. 


\section{The Newer Varieties of Choice Grapes.}

We offer a splendid stock of the NewEST AND CHOICEST VARIETIES of HARDY GRAPES FOR FAMILY USE, for which we cordially invite the orders of our friends and customers. Our Grape Vines are grown by special methods from thoroughly well-ripened wood, and cannot be surpassed for HEALTH, VIGOR, AND EARLY BEARING. We offer both one and two-year sizes. The ONE-YEAR VINES are strong, heavy-rooted plants, sure to grow and come quickly into bearing, and can be sent by Mail or Express. The TwO-YEAR VINES cost a little more, but are much larger and stronger; as they are too large to go by Mail, they must invariably be sent by Express.

Brighton.-One of the finest New Red Grapes; large size, excellent quality, very early. I5 cts. and $25 \mathrm{cts}$. each.

Catawba.-This fine old variety is well known and much esteemed; one of the bcst for city yards. I5 cts. and $25 \mathrm{cts}$.

Concord.-Emphatically the Grape for the million; succeeds over a wider range of territory than any other; black, early and immensely productive. $15 \mathrm{cts}$. and $25 \mathrm{cts}$. each.

Delaware.-Esteemed ore of the very finest varieties exquisite flavor, hardy and productive. $20 \mathrm{cts}$. and $30 \mathrm{cts}$. each.

Duchess.-One of the best Newer Varieties; large clusters of pale-yellow grapes, rich and excellent, $20 \mathrm{cts}$, and $30 \mathrm{cts}$. each.

Early Victor.-New, and believed to be the best Very Early Grape yet introduced; it is large, black and very sweet; hardy and productive, $25 \mathrm{cts}$, and $35 \mathrm{cts}$. each.

Jefferson.-Color, bright red, with fine bloom; large size, excellent quality, tender and rich. $25 \mathrm{cts}$. and $35 \mathrm{cts}$. each.

Moore's Diamond.-This splendid New Grape is a cross between Concord and Iona; in habit of growth it resembles Concord, while the quality of fruit is equal to the best tender sorts; ripens two to three weeks earlier than Concord; skin smooth and delicate greenish white in color; few seeds, very juicy and so free from pulp that fruit held against the light appears almost transparent; the best New White Grape. $50 \mathrm{cts}$, and $60 \mathrm{cts}$. each.

Moore's Early.-New, and believed to be the finest VERY EARLY BLACK GRAPE; a vigorous grower, entirely hardy; large, very juicy and sweet. $25 \mathrm{cts}$. and $35 \mathrm{cts}$, each.

Niagara. - The most celebrated NEW WHITE GRAPE EVER INTRODUCED; bunches very large; color, greenish white, with fine bloom; quality exceedingly fine; vine vigorous and entirely hardy; a heavy and regular bearer; should be planted by all. $20 \mathrm{cts}$. and $30 \mathrm{cts}$. each.

Golden Pocklington.- Hardy and good color, beautiful light canary yellow; clear, juicy and sweet; fine, large, compact bunches; bears well. $20 \mathrm{cts}$. and $30 \mathrm{cts}$. each.

Salem. - A standard variety, one of the best; large and very fine; rich golden-red color; flesh sweet and tender; vigorous and hardy. $20 \mathrm{cts}$, and $30 \mathrm{cts}$, each.

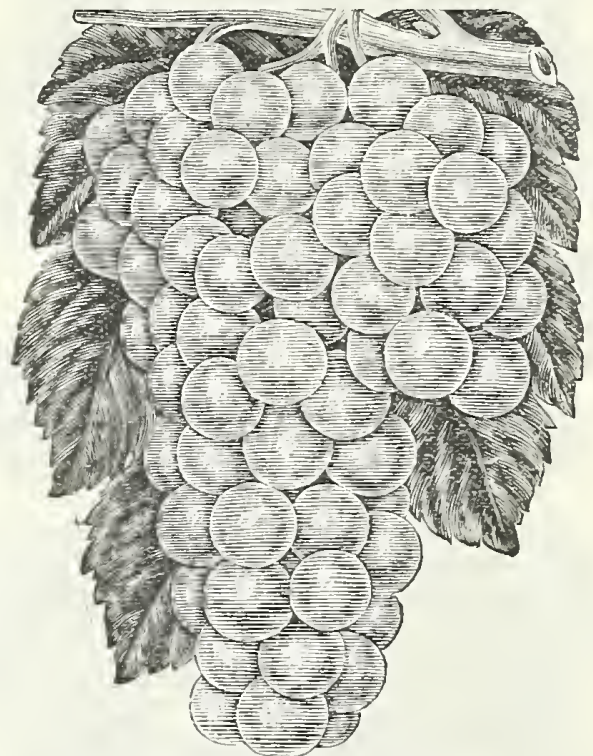

NIAGARA GRAPES, 20 AND 30 CTS.

Wordens.-Splendid New Black Grape; flesh tender, juicy and melting; hardy and productive. $20 \mathrm{cts}$. and $30 \mathrm{cts}$. Empire State.-This New Grape pleases planters in widedifferent sections; it should be better known; large and fine; color, greenish white; originated on the Hudson and believed to be valuable. $30 \mathrm{cts}$. and $40 \mathrm{cts}$, each.

Wyoming 'Red.-A New Red Grape; resembles Delaware in color and flavor, but is much larger; ripens early and is vigorous, hardy and productive. $25 \mathrm{cts}$. and $35 \mathrm{cts}$. each.

NOTICE.-THE ONE-YEAR VINES ARE THE LOWEST PRICED.- Those at 15 cts. are \$1.50 per doz.; 20 cts., $\$ 2.25$ per doz.; 25 cts., $\$ 2.50$ per doz.; 30 cts., $\$ 3$ per doz.; 50 cts., $\$ 5$ per doz. THF TWO-YEAR VINES ARE THE HIGHEST PRICED (by Express only).-Those at 25 cts. are \$2.50 per doz.; 30 cts., $\$ 3$ per doz.; 35 cts., \$3.50 per doz.; 40 cts., \$4 per doz.; 45 cts., \$4.50 per doz.; 60 cts., $\$ 6$ per doz. Set of 15 Varieties of Grapes, One-year Size, \$3.25; Two-year Size, \$4.75.

\section{THE NEW INDUSTRY GOOSEBERRY。}

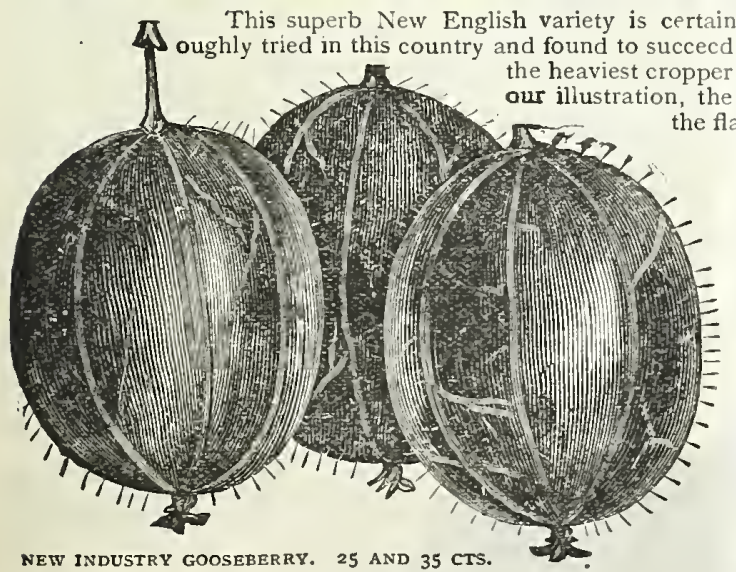

Larger size, $20 \mathrm{cts}$. each; 3 for $50 \mathrm{cts}$.: I2 for $\$ 2$. Strong Plants, which we imported direct from the introducers. We strongly recommend the extensive planting of this unequaled New Gooseberry. Price, $25 \mathrm{cts}$. each ; 5 for $\$ I$; I 2 for $\$ 2.25$; I00 for \$I 4.50. Larger size, $35 \mathrm{cts}$. each; 4 for $\$ I$; I2 for $\$ 3 ;$ IOO for $\$ 16.50$.

\section{HOUGHTON GOOSEBERRY.}

Pale red in color, very sweet, tender, and one of the best. Plants of branching, spreading habit; enormously productive, ro cts, each ; 6 for $50 \mathrm{cts}$.; I 2 for \$I. Larger size, I5 cts. each ; 4 for $50 \mathrm{cts}$.; I2 for $\$ 1.25$.

\section{DOWNING GOOSEBERRY.}

This well-known variety is unsurpassed for cooking and table use; fruit, handsome pale green. A vigorous grower, free from mildew and very prolific. I5 cts. each; 


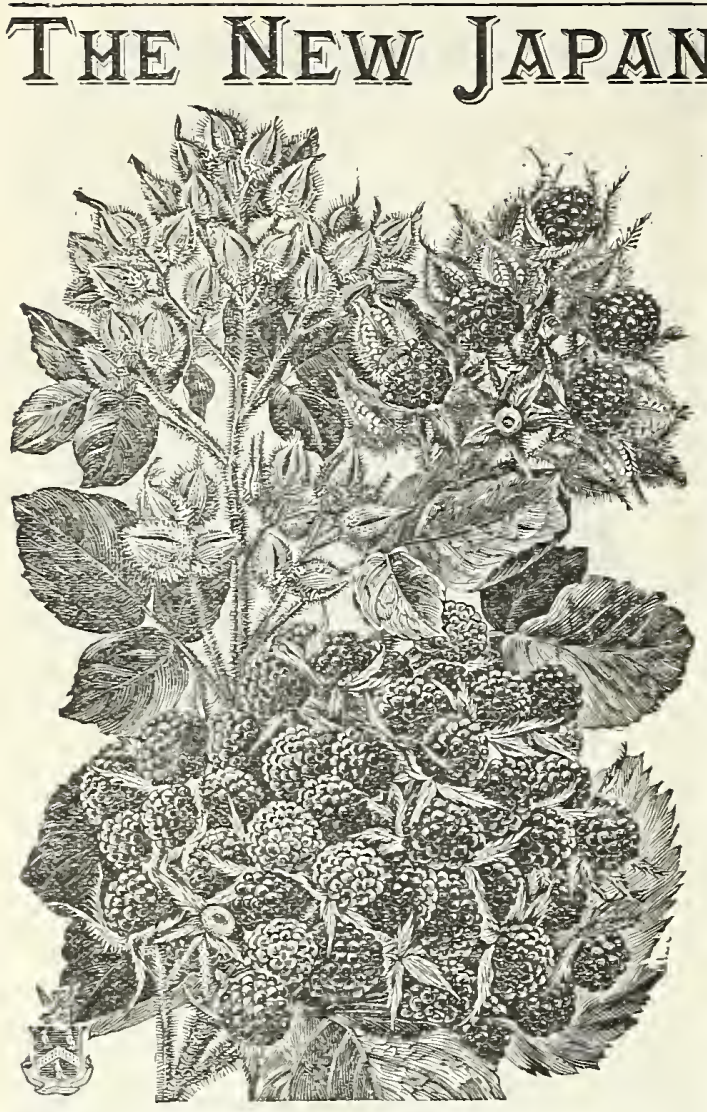

NEW JAPANESE WINEBERRY. MUCH REDUCED IN SIZE.

We think quite favorably of this great novelty. Prof Georgeson, of the Japanese Agricultural College, found it while traveling in the interior of Japan, and he was so much impressed with it that he sent seed to this country to be grown, as he considered it would be a valuable addition to our hardy fruits. We quote from the description of the introducer:

"It belongs to the Raspberry family; is a strong, vigorous grower, attaining the usual height of a Raspberry, and is perfectly hardy in all positions without protection. It is, in fact, more hardy and vigorous than any Raspberry or Blackberry. It stands alike the cold of the northern Winters and the heat of the southern Summers, without the slightest degree of injury. Its leaves are of the darkest green outside, and silvery white underneath. The young shoots and branches are covered with a reddish brown hair or moss. The fruit is borne in large clusters, often 75 to roo berries in a bunch. These berries are from the time of formation and bloom, until they ripen, enclosed in a 'burr,' which is formed by the calyx covering them entirely, When ripe the burr opens, exhibiting a large berry of the brightest, light, glossy scarlet or sherry wine color. The burrs and stems are covered with a heavy reddish moss, IIKE A MOSS ROSE BUD. The flavor of the fruit is entirely different from any other berry, being very sprightly, sweet and juicy, having no disagreeable sour, but a delicate and luscious flavor peculiar to itself, and superior to other berries. It is very juicy and makes the finest quality of wine. It commences to ripen early in July, and continues in bearing for a long time. It is the most prolific berry known, the bushes oeing literally covered with its luscious fruit.

Prices.-We offer by Mail, postpaid, plants that will fruit this season, $25 \mathrm{cts}$. each; 5 for \$I. Extra size, $40 \mathrm{cts}$, each; 3 for $\$ I$.

\section{EDITOR OF THE "RURAL NEW YORKER" SAYS:}

"The Wineberry is the Rubus phœnicolacius of private collections. It is a most remarkable Raspberry, worthy of a place in every collection. The forming berry is enclosed within the calyx-sepals which are covered with purple viscid hairs like the bud of the Moss Rose. The berries are juicy and of a refreshing sprightly quality."

\section{CHILDS' EVER-BE ARING TREE BLACKBERRY.}

This distinct Blackberry is so mucb asked for and evidently gives such great satisfaction that, at last, we concluded to offer it. We quote from tbe description of the introducer, who supplied us a fine fine tree form, straight and erect, requiring no stake. The berries are of enormous size, equaled only by the Erie; borne in great clusters, whicb commence to ripen early in July and continue into September, making its fruiting period fully two months or more. The finest 81 lackberries we ever ate we picked about September Ist from some of these plants, which had been ripening fruit since July 8 th. They are the finest

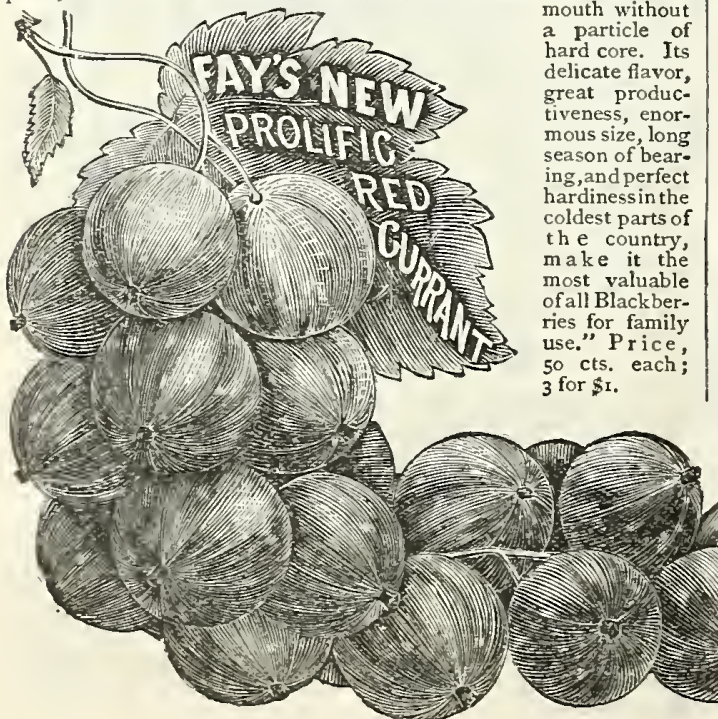

\section{CRANDALL TREE CURRANT.}

We offer a fine stock of the true Crandall Tree Currant, and indorse the description of the introducer, as follows:

"It is perfectly hardy in every respect, and as the roots run deep, heat and drought do not affect it ine other small fruits ; a remarkably "It ranges in size from Delaware Grape to the Concord Grape. Berries $5 / 8$-inch in diameter are very common, while many measure -inch, and a few were found that were about $7 / 8$-inch, and on bushes at were only one year transplanted.

"It is wonderfully productive, yielding more than any other small

"It has a most excellent flavor peculiar to itself and liked by every one who has tasted it in pies, jam or jelly. It has none of the peculiar flavor of Lee's Prolific and other Englisb Black Currants so disagree-

able to many tastes.
"It begins to ripen here about the middle of July and continues to the middle of August, and will hang on the bushes a long time after it is ripe, partially drying instead of rotting.

"When fully ripe it is of a shiny bluish black, and from their size and color they have often been taken for grapes at first sight.

The plants we offer of the Crandall Currant are grown from short Cuttings by our own special methods, made from stock plants of the genuine variety which we procured of the original introducers. $35 \mathrm{cts}$. each; 3 for $\$ I$.

\section{THE BEST CURRANTS.}

Fay's Prolific. - This well-tried New variety of Currant is undoubtedly one of the very best in cultivation both for market and home use. It is a very beavy cropper: the large uniform berries are less acid than any other sort; large, handsome strings of fruit; unexcelled for the family garden or market. $15 \mathrm{cts}$. eacb; 6 for $75 \mathrm{cts}$; 12 for $\$ 1.50$. Larger size, $20 \mathrm{cts}$. each; 6 for $\$ I$; I2 for $\$ 2$.

Cherry.-Fine large berries, excellent quality; plants vigorous and very productive: thoirght by some equal to Fay's Prolific. so cts. 17. each; 6 for 50 cts.; I2 for $\$ 1$.

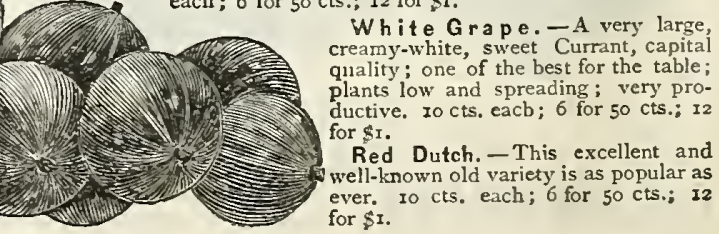
White Grape.-A very large, This uctive, Io cts, eacb; 6 for $50 \mathrm{cts}$.; I2

Red Dutch. - This excellent and ever. Io cts. each ; 6 for 50 cts.; I2 

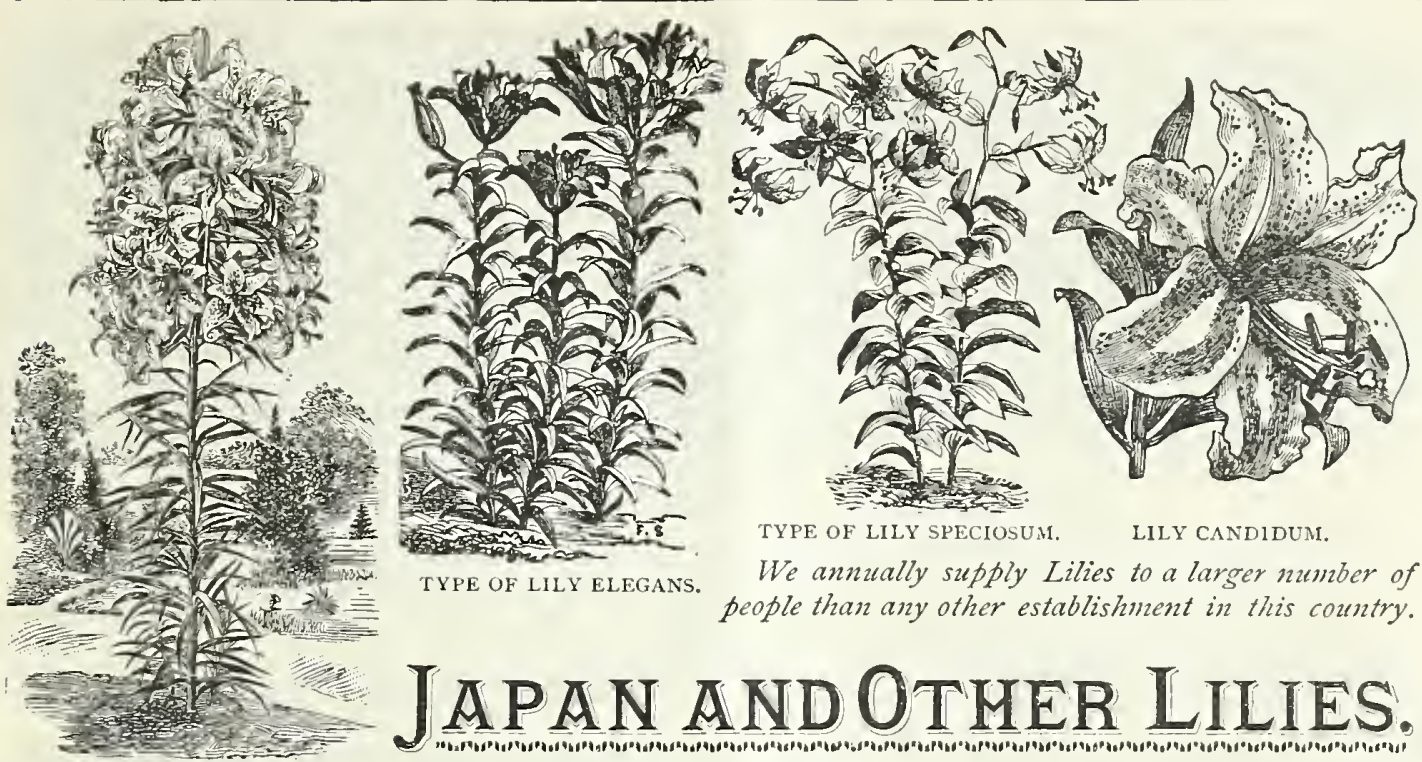

TYPE OF LILY ELEGANS.

TYPE OF LILY SPECIOSUM.

LILY CANDLDUM.

LILY AURATUM.

DIRECTIONS FOR CULTURE.-Lily bulbs should be planted quite deep, say not less than six to eight inches. Unlike most other flowers, they do not need strong ground or manure, but thrive best in a partially shaded situation, sheltered by shrubbery and other plants. They are entirely hardy, and need no protection in Winter, though in exposed situations it is advisable to give a slight covering of leaves or coarse litter when convenient. Lilies increase in size and beauty with age, and should be left undisturbed from year to year. When the best effect is desired, we recommend planting one or two dozen of a kind, rather than one or two each of several kinds; they are very desirable, and always give satisfaction.

\section{Lilies can be planted in Spring or Fall, as preferred.}

\section{Lilium Auratum.}

\section{The Golden Rayed Lily of Japan.}

This magnificent variety is the finest of all Lilies; a clump of it in full bloom is worth going a long way to see. The strong, straight stalks grow 3 to 6 feet in height, and are well able to bear the superb clusters of great blossoms they produce; the magnificent flowers are often a foot across. The color is pure white, exquisitely spotted with rose, and rayed and banded with golden yellow in the most beautiful manner; maroon-tipped stamens in high contrast with the flowers. This noble Lily is certainly one of the most valuable and ornamental of flowers, and should be planted by every one.

We offer Auratum Bulbs in 3 Sizes. All are fine strong bulbs, sure to bloom the present season; the only difference is the size.

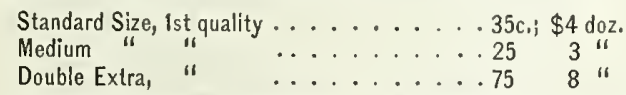

Auratum Rubra Vittatum.-Nagnificent flowers, very large size; waxy white, with a broad, blood-red stripe through each petal; very striking. $75 \mathrm{cts}$, each.

Batemanii.-New and very desirable; color, rich apricot yellow, not spotted. $40 \mathrm{cts}$. each; $\$+$ per doz.

Brownii.-One of the most magnificent varieties; fine folinge; flowers very large and of splendid. trumpet shape; color, white inside, rich purple outside; the stamens are a rich chocolate color, and form a very distinct feature of this species. \$I.25 each.

Candidum.-The old white garden Lily (not Japan); a splendid sort; elegant, large, pure white flowers in clusters. blooms earlier than the others, but not always the first year. 20 cts. each; \$2 per doz

Canadense. - This beautiful native Lily is grace itself: the lovely bell-shaped, drooping flowers are clear red and yeilow; at the low price offered, it should be in every order. I $5 \mathrm{cts}$. each; $\$$ I. 25 per doz.

Chalcedonicum. - This magnificcnt Lily is rare and scarce; should be in every collection; strong-growing, stately and free-blooming flowers of fine recurved shape; color, intense scarlet. $75 \mathrm{cts}$, each: $\$ 8$ per doz.
Coridion.-This distinct and beautiful variety is very scarce and rare; the flowers are of medium size, perfectly formed and produced in great profusion. Color, brightest yellow, scattered over, principally on lower petals, with clear reddish spots. $30 \mathrm{cts}$, each; $\$ 3$ per doz.

Colchesteri.-Immense, trumpet-shaped flowers of perfect form; inside snow white, outside chocolate, without a golden ground; most superb. \$I each, by Mail.

Excelsum - " This remarkable Lily attains the wonderful height of 5 to 6 feet. It produces from 8 to 12 nodding, rich apricot-hued blooms; has a delightful perfume, and its stately form makes it attract attention wherever grown." $60 \mathrm{cts}$. each, by Mail ; $\$ 5$ per doz., by Express.

Harrisi (Bermuda Easter Lily). - While in great demand for Winter flowering, this superb variety is almost equally valuable for general planting. North of Washington, D. C., should have protection during Winter. $35 \mathrm{cts}$. each.

Leichtlinii.-This beautiful Japanese species is of neat and elegant habit; the flowers are borne in numbers, and are pure canary yellow, with intense crimson spots; a valuable acquisition. $75 \mathrm{cts}$, each ; $\$ 8$ per doz.

Longiflorum.-The well-known, beautiful, snow-whitc fragrant Lily. Fine for forcing and handsome in the garden. 20 cts, each: \$2 per doz.

Martagon (Turk's Cap).-Various colors mixed. $15 \mathrm{cts.}$ ach; \$2 per doz.

- Dalmaticum.-A most remarkable Lily; flowers twice the usual Martagon size; intense blackish purple; the darkest Lily known. $75 \mathrm{cts}$, each.

Monadelphum. - This splendid variety is entirely distinct and very attractive; flowers are produced in abundance on stately stalks; color, rich reddish yellow, finely spotted et black. $60 \mathrm{cts}$. each; $\$ 6$ per doz.

Pomponium Verum.-Blooms the earliest of any Lily we offer; a profusion of fiery scarlet flowers; grows about 3 feet. $60 \mathrm{cts}$. each; $\$ 6$ per doz.

Pulchellum.- "A fitting companion to Tenuifolium, blooming at the same time. The flowers spread their petals at nearly right angles, so that, when in full bloom, a bed of them presents a solid mass of rich bright crimson flowers. The shape is most remarkable; the bulbs are as vigorous and hardy as a Tiger Lily." Strong bulbs, $30 \mathrm{cts}$, each. 
Japan and Other Lilies (Continued).

SPECIOSUM, or Lancifolium, are the most popular and satisfactory of all Lilies; we offer below six different varieties, all of which are distinct, graceful and very beautiful. This class of Lilies is the easiest grown of any.

- Album Krætzeri.-A rare and magnificent variety immense white flowers of great substance, greenish band running through the centre of each petal; lemon-yellow anthers; very distinct. $95 \mathrm{rts}$, each.

- Album Præcox. - A magnificent Lily; throws up tall stems, bearing from 5 to 25 splendid large flowers; color, pure white, beautifully tinged with carmine and rose; very fragrant. $50 \mathrm{cts}$. each ; $\$ 5$ per doz.

- Japan Melpomene.-A magnificent, new, large-flowering variety; vigorous grower and free bloomer; color, intense deep crimson. $50 \mathrm{cts}$. each ; $\$ 5$ per doz.

- Roseum.-A superb flower; blooms in clusters; very large, fine form; white and bright. rose, spotted. $20 \mathrm{cts}$. each ; \$2 per doz.

- Rubrum.-One of the finest of Japan Lilies; bright crimson and white spotted; splendid large flowers, borne in clusters; stem 2 to 3 feet. $20 \mathrm{cts}$. each; $\$ 2$ per doz.

- Superbum. - One of the best and handsolnest Lilies; very tall and stately; bears enormous clusters of superb orange and scarlet flowers. $20 \mathrm{cts}$. each; $\$ 2$ per doz.

Coral Lily of Siberia (L. Tenuifolium). - This charming Lily well deserves the attention it has created. The flowers and foliage present the most elegant appearance; the petals are wax-like and beautifully reflexed; the color is dazzling vermilion scarlet, and as the flowers are suspended on drooping graceful stems, the effect is exquisite; perfectly hardy, Large bulbs, $30 \mathrm{cts}$. each; $\$ 3$ per doz.

Tigrinum fl. pl. (Double Tiger Lily).-This magnifcent Lily is borne in immense clusters on tall stems; the flowers are very large, frequently 6 inches across, and very double; color, deep fiery red, spotted with black; any illustration gives but a faint idea of the showiness of this superb Lily; should be in every order. $20 \mathrm{cts}$, each; 2 for $40 \mathrm{cts}$.; $\$ 2$ per doz.

Tigrinum Splendens (Single Tiger Lily).-This splendid Lily is one of the best in the list; the stem is tall; the flowers large and elegantly formed; blooms in large clusters; color, brilliant orange scarlet, with intense black spots; remains in bloom a long time. $20 \mathrm{cts}$. each; $\$ 2$ per doz.

Wallaceii.-A new and magnificent Japanese variety, with beautiful clear buff flowers, elegantly spotted with black. $40 \mathrm{cts}$. each; \$4 per doz.

\section{Lilium Elegans.}

The Elegans type of Lily (also known as Thunbergianum) is among the best hardy varieties. The large, bell-shaped flowers are borne upright and are produced in great profusion.

Aurea Maculatum.-Bright, rich rose; a blotch about one-third the size of each petal running from base to nearly the tip of the petals, of pure light lemon; a flower of striking effect and form. Both colors are of intensely bright and pleasing tints, and the contrast is very effective. One foot high and blooms about two weeks later than most of the Elegans type. 30 cts. each; $\$ 3$ per doz.

Elegans Aurora.-Grow 2 to 4 feet high, inside of cup deep rich orange; tips of petals suffused with deepest crimson ; a most beautiful Lily. $50 \mathrm{cts}$. each; $\$ 5$ per doz.

Leonard Joerg.--Rich rose, with deep orange blotch beautiful glossy foliage. $25 \mathrm{cts}$. each ; \$2 per doz,

Elegans Mixed Varieties.-This class includes some of the most beautiful Lilies. The flowers are mostly borne in clusters; the colors are the richest hues of yellow and red; splendid for planting in masses. $20 \mathrm{cts}$. each; \$2 per doz.

\section{California Lilies.}

Humboldtii.-A superb and very scarce variety; grows 3 to 5 feet high. The magnificent large flowers are of rich golden-yellow color, spotted with royal purple. $50 \mathrm{cts}$, each; $\$ 4$ per doz.

Pardalinum.--A very handsome and distinct variety: color, scarlet, shading to rich yellow. $25 \mathrm{cts}$. each; $\$ 2$ per doz.

Parryi. - The petals are about 3 inches long, with beautifully recurvcd tips; color, clear lemon yellow, with small purple dots at base; very fragrant. This splendid variety should be in every collection. $50 \mathrm{cts}$. each; $\$ 4$ per doz.

Washingtonianum.-At last we have a fine stock of this beautiful California Lily. A very strong grower; flowers of magnificent size; color, pearly white and purple. $45 \mathrm{cts}$. each. \$4 per doz

SPECIAL OFFER. -We send the entire collection of Lilies, 35 varieties, for $\$ 12.50$.

\section{Tuberous= Rooted Begonias.}

Tuberous-rooted Begonias are new and distinctly beautiful flowers, which can be grown and cared for as easily as Geraniums. The large and healthy American-grown bulbs we send out produce all Summer in profusion, gorgeous and brilliant flowers, 3 to 5 inches in diameter. An entirely new effect.

These splendid new Begonias are very beautiful and unsurpassed for bedding or pot culture. As will be seen by our illustration, the plants present a striking appearance, being covered with magnificent showy flowers. The bulbs or tubers can be easily grown, succeeding best, however, in light, loamy soil and a somewhat shaded situation. After bloom ing all Summer, the bulbs, if in beds, should be taken up in November, dried off like Gladiolus or Tuberoses, and packed in a box of coarse sand or saw-dust, placed in a dry place, secure from cold; they will then be ready for the next season. If in pots, they can be gradually dried off in November by withholding water; when well dried out, put the pots containing bulbs in a dry warm place, until the next April, when the roots can be shaken out and replanted for Summer flowering as before.

\section{Tuberous=Rooted Begonias. Superb Mixed Colors.}

Our superb collection of Tuberous-rooted Begonias, Mixed, embraces the most gorgeous array of colors ever seen in this magnificent new race of flowers. A bed of a dozen bulbs, costing but $\$ 2$, will excite admiration, and attract great attention in any locality, while single bulbs, planted in the mixed flower beds or pots, vases or boxes, will appear in exceedingly handsome contrast. $20 \mathrm{cts}$. each; 3 for $55 \mathrm{cts}$; 6 for $\$ 1 ; 12$ for $\$ 2 ; 25$ for $\$ 4 ; 50$ for $\$ 8 ;$ Ioo for $\$ 15$.

\section{Tuberous=Rooted Begonias Under Color.}

Begonia-Superb Scarlet. - Intense flame-colored flowers, very large size. $30 \mathrm{cts}$. each.

Begonia-Superb Rose.-The beautiful flowers are soft, shining rose color. $30 \mathrm{cts}$. each.

Begonia-Superb White.-Large, pearly white flowers, ery distinct. $30 \mathrm{cts}$. each.

Begonia-Superb Yellow.-Brilliant and glowing yellow color. $30 \mathrm{cts}$, each.

SPECIAL OFFER,--One bulb each of the 4 superb colors described above for $\$ 1$.

Tuberous-rooted Begonias, Double Varieties Mixed, all colors. Very rare, 50 cts, each; I2 for $\$ 5$.

\section{Gloxinia Crassifolia Grandiflora.}

Gloxinia Crassifolia Grandiflora, or Improved New French Strains of Gloxinias here offered, are the most improved and beautiful race of Gloxinias now known. The plants are of vigorous and healthy habit of growth, with foliage of velvety green, surmounted with clusters of lovely trumpet-shaped flowers, which conbine colors, shadings, markings and blendings in distinct and exquisite beauty seen in no other flowers. The plants are easily grown from the large bulbs we send out. They succeed best in pots or boxes; if set in the open ground, they should be placed in a somewhat shaded situation. When the plants have done blooming they can be gradually dried off like Calla Liliesand kept during Winter in a moderately warm dry place; they will then be ready for starting into bloom the next season. We offer fine, strong American-grown bulbs in mixture, which includes the best colors only, all the dull and undesirable shades having been discarded. Fine, strong bulbs, price, 25 cts.; 3 for 60 cts.; 5 for $\$ I$; I 2 for $\$ 2.25$.

\section{Coperia Drummondi.}

One of the easiest of all bulbs to grow and absolutely sure to bloom freely the first season; equally desirable for the flower beds or pots. It is of the Amaryllis family, the bulbs being large and solid, sending up fine foliage and flower stalks Io to I5 inches high, producing in great profusion large, beautiful Lily-like flowers, snow white in color. In the Fall the bulbs can be lifted and stored like Gladiolus or Tuberoses, and will be ready for planting out again the following Spring. We have a large stock of strong bulbs, sure to bloom; should be in every order. 15 cts. each; 2 for 25 cts.; 4 for 50 cts.; \$1.25 per doz. 


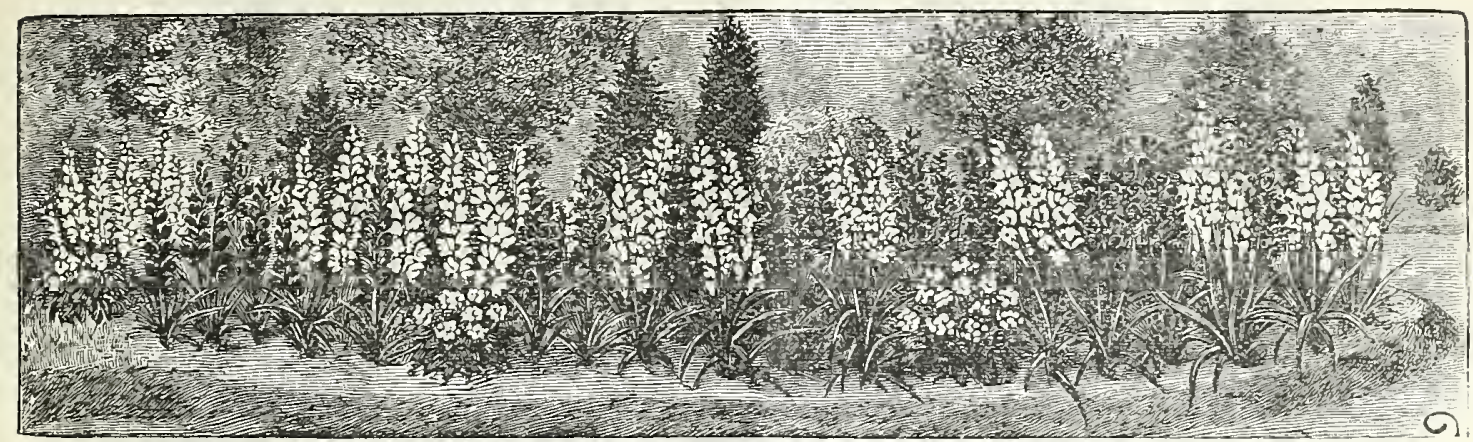

\section{Our Magnificent Gladiolus.}

Gladiolus are the gay bright flowers of Summer days. In point of popularity they occupy the same place in Summcr Flowering Bulbs that Tulips do among Fall Bulbs. We know Gladiolus thoroughly, have the advantage of the best and largest stock in the country, and whether you want one named bulb, or rooo for massing, ours is the place to get them. They are Easy to Grow and Sure to Bloom. Plant (after danger of freezing is past) in ordinary soil, 3 inches deep and 6 or 8 inches apart, and they will soon throw up tall spikes of bcautiful fiowers of the most brilliant and gorgeous colors, crimson, scarlet, purple, orange, white, etc., with all imaginable shades and markings. They are superbly beautiful, and attract more attention than any other flower of their season. By planting at two or three different times you can liave a constant succession of bloom.

\section{Our Splendid Seedling Gladiolus.}

OUR SPLENDID SEEDLING GLADIOLUS have become almost as famous as our Roses; their wonderful beauty has attracted great attention, and they are extensively planted in every State and Territory in the Union. These magnificent Gladiolus are grown from the Finest Selected French Hybrids, and are really the Finest Strains of Gladiolus ever produced:

PRICE. - FINEST SELECTED SEEDLINGS, Strong Bulbs, Warranted to Bloom, free by Mail, $10 \mathrm{cts}$. each; 3 for 25 ets.; 6 for 40 cts.; $75 \mathrm{cts}$. per doz.

By Express, 25 for $\$ 1.25$; 50 for $\$ 2.50$; $\$ 5$ per $100 ; 500$ for $\$ 20 ; 1000$ for $\$ 37.50$.

\section{Fine Mixed Gladiolus.}

Our fine mixed Gladiolus are made up of the very choicest strains, and include all beautiful colors. Please notice our low prices for these large blooming Bulbs. By Mail postpaid, 6 for 25 cts.; 12 for 50 cts.; 25 for $\$ 1$; 100 for \$3.75. By Express, 50 for $\$ 1.50 ; 100$ for $\$ 2.75$; 1000 for $\$ 26.50$. SECOND SIZE-Sure to bloom this Summer-Postpaid, 6 for 15 cts.; 12 for 30 cts.; 50 for 80 cts.; 100 for $\$ 1.60$. By Express, 100 for $\$ 1.30 ; 500$ for $\$ 6.25 ; 1000$ for $\$ 12.25$.

Fine Gladiolus in Separate Colors.

Red Assorted Shades, 4 for $25 \mathrm{cts}$; $65 \mathrm{cts}$. per doz.

White and Light, 3 for $25 \mathrm{cts}$.; $90 \mathrm{cts}$. per doz.

Pink and Striped, 3 for $25 \mathrm{cts}$.; $90 \mathrm{cts}$. per doz.

Yellow and Buff, 3 for $25 \mathrm{cts}$.; \$I per doz.

Striped and Variegated, very handsome, 3 for 25 cts.; 90 cts. per doz.

\section{Our Big 50 Cent Set, ro Splendid Named Gladiolus.}

A large stock of the following varieties allows us to make the unprecedented offer of the entire set of Ten for 50 Cts.; all are distinct, true to name, and each variety labeled; this set of named Gladiolus for $50 \mathrm{cts}$. is unsurpassed, and bears no comparison to any set for the money ever offered. All labeled.

Angele.-A very distinct color, almost white.

Addison.-Clear carmine, grand spikes.

Brenchleyensis.-Large spikes flaming vermilion scarlet. Carnation.-Marked and flamed like a carnation flower. Eugene Scribe. - Striking velvety vermilion.

Isaac Buchanan.-White, slightly threaded rose.

John Bull.-White, tinged with sulphur yellow.

Madame Dumortier.-Rose and purple.

Stella.-Very fine white, flamed with carmine.

Sylphide.-White ground, tinted rose.

The Entire Set of Ten nanied above for 50 cts., Postpaid,

\section{A Set of Ten Extra Choice Named Gladiolus for $\$$ I.}

We will send by Mail, postpaid, for $\$ T$, the set of TEN EXTRA CHOICE named Gladiolus described below. This set forms a combination of beauty seldom seen for the money. All iabeled.

Antiope.--Superb light orange scarlet.

Augusta.-Named in honor of the Empress of Germany ; grand spikes of nearly white flowers.

Vameleon.-Lilac-colored flowers, banded and flamed with orange, violet mark.

Crystal Palace.--Shining carmine, veined rose.

Diamant.-Carmine vividly marked on whitc.

Fatma.-Ivory white ground, striped rosy purple.

Flamboyant.-Splendid, fiery red, clouded rich purple.

Lacandeur.-Lovely white, striped violet.

Princess Conde.-Light orange red and white.

Zenobia.-Rose and violet, flamed carmine.

The Entire set of $T$ en named above for $\$ \mathbf{~}$, Postpaid.

New Gladiolus Snow White.

The famous and long-looked-for Snow White Gladiolus. For an accurate description of this superb novelty we quote from the notes of the grower and introducer: "It is the only really pure white Gladiolus known; the spikes are of large size, set solidly with flowers from bottom to top; the flowers are of the most beautiful shape, exquisitely recurved and crisped; the superb spikes of bloom remain the same pure color week after week, withstanding hot sun and wet weather. The large bulbs send up vigorous and healthy plants, cach bulb producing a number of spikes." $25 \mathrm{cts}$. each; 3 for 75 cts.; 6 for $\$ 1.25$; I2 for $\$ 2.50$.

New Gladiolus Africain.

This orand variety is the darkest colored Gladiolus now known $i$ surc to please all who like distinct and novel flowers; color rich slaty brown, finely streaked with shining dark crimson and pure white. $30 \mathrm{cts}$. each; 6 for \$1.50.

\section{New Gladiolus The Sultan.}

This grand Gladiolus pleased the Turkish Minister so much that he requested that some bulbs be sent to the Sultan of his country. Large spikes, tawny salmon color. $50 \mathrm{cts}$.

\section{each. New Gladiolus Mr. Bains.}

This new English variety is strongly recommended as the most distinct scarlet crimson, a remarkably solid and brillian effect; superb spike. We are confident that this rare variety vill please the most critical amateurs, 45 cts. each; 3 for \$I.Io,

Special Offer.-We will scnd this collection of four the most distinct Gladiolus ever offered-by Mail, postpaid, for $\$ 1.10 ; 2$ sets for $\$ 2 ; 5$ sets for $\$ 4$ 


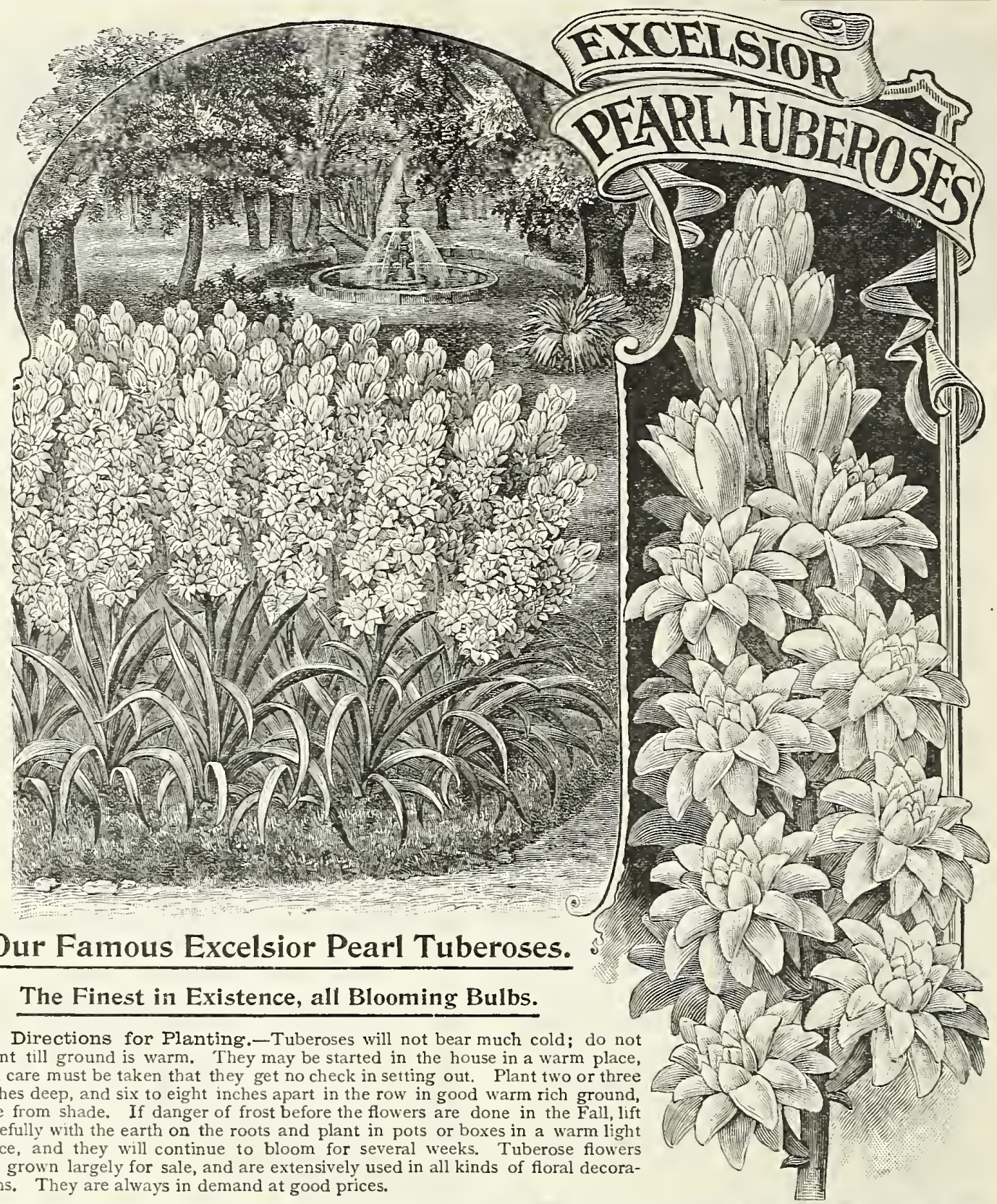

Dwarf Excelsior Pearl Tuberose.-A splendid new variety, the finest ever introduced. We ask attention to our engraving of a group. This new selection is greatly superior to the Common Pearl; grows about 18 inches high, blooms very early, matures perfectly; flowers pure white, large size, very double and intensely sweet. We send splendid, large, wellripened bulbs, the finest ever grown, all sure to bloom; gives immense satisfaction every year.

Notice Prices.-Extra-fine, Large, Flowering Bulbs, Dwarf Excelsior Pearl Tuberoses, 5 cts. each.; 3 for $15 \mathrm{cts.;}$ $50 \mathrm{cts}$. per doz; \$ 3.50 per Ioo.

Largest Size Selected.-Dwarf Excelsior Pearl Tuberoses 10 cts. each ; 3 for 25 cts.; 6 for 50 cts.; \$I per doz.; \$6 per Ioo.

Orange-Flowered Tuberose.-This is a very beautiful Tuberose, with elegant single flowers; it is considered more hardy than the double varieties, and more certain to bloom: it also blooms much earlier in the season; the flowers are pure snowy white, and very sweet, rivaling orange blossoms; strong blooming bulbs, Io cts, each ; 3 for $25 \mathrm{cts}$.; 6 for $50 \mathrm{cts}$; $\$$ I per doz,

New Variegated-Ieaved Tuberose.--This handsome new variety is one of the prettiest novelties yet offered; its deep green leaves are finely edged and bordered with broad stripes of creamy white; the flowers are star-shaped, very large and of exquisite fragrance. It blooms several weeks earlier than other Tuberoses, which adds greatly to its value, and if kept in cellar over Winter, the bulbs will continue to bloom year after year. I5 cts, each; 3 for $30 \mathrm{cts}$; 6 for 5octs.; \$I per doz.

\section{Two Splendid Sets of Tuberoses.}

Set No. 1.-For Fifty Cents, we will send by Mail, postpaid, Io Tuberoses, selected as follows: 6 Excelsior Pearl, 2 Orange-Flowered, and 2 New Variegated-Leaved, Io in all, for $50 \mathrm{cts}$.

Set No. 2.-For One Dollar, we will send by Mail, postpaid, 20 Tuberoses, selected as follows: Io Excelsior Pearl, 5 Orange-Flowered, and 5 New Variegated-Leaved, 20 in all, for \$1. 


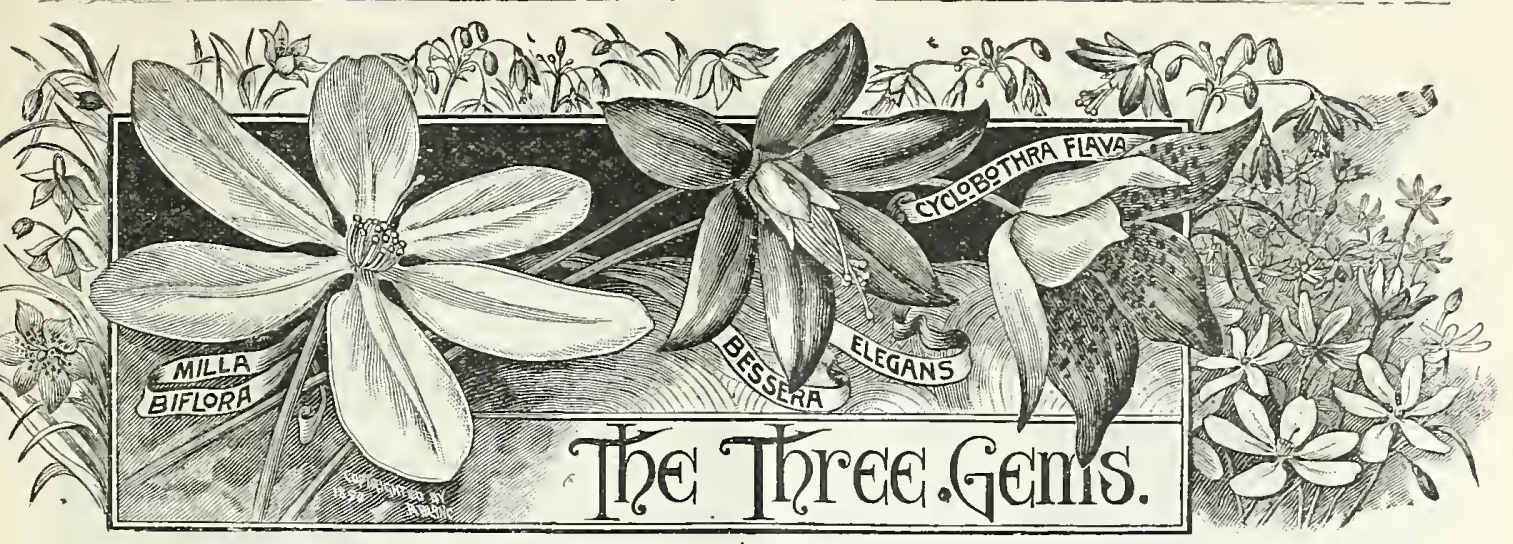

The Three Gems.

These lovely flowers are a delight to all who plant them; sure to bloom; in beautiful contrast. We offer large bulbs, home grown, for one season. Cost only $20 \mathrm{cts}$. a Set.

Milla Biflora (Floating Star).-This charming novelty of recent introduction blooins profusely all Summer; the flowers are fult three inches in diametcr, and pure waxy white; they are borne in pairs on slender rush-like stems, and as they are gently stirred by the passing breeze, remind one of FLOATING STARS. The petals are of great substance, and flower stalks cut and placed in water will keep blooming for a week or more. Io cts. each ; 3 for 25 cts.; \$I per doz.

Bessera Elegans (Coral Drops).--This beautiful variety is the direct counterpart of Milla Biflora in rich and striking color, cqualing it in graceful beauty. Pendulous clusters of bell-shaped flowers are borne on long slender stems. The color is a striking shade of coral scarlet, with pure white cup and dark-blue anthers. Io cts. each; 3 for $25 \mathrm{cts;} \mathrm{\$ I} \mathrm{per} \mathrm{doz.}$

Cyclobothera Flavia (Golden Shell).-This golden gem is of great beauty and easily grown; the habit of the plant and bloom is similar to Bessera; the color is clear golden yellow, with intense black dots on each petal. Fine bulbs, Io cts, each; 3 for 25 cts.; $\$$ I per doz.

SPECIAL OFFER. - The Set of 3 Gems for $20 \mathrm{cts} . ; 3$ of each variety, 9 in all, for $55 \mathrm{cts}$; 5 of each, 15 in all, $80 \mathrm{cts}$.

\section{Montbretia Crocosmiæilora.}

This extremely brilliant and graceful Summer flowering bulb should be better known. Each bulb throws up several flower stalks, which are loaded with slightly droopy spikes of blossoms from 5 to Io inches long; also with numerous side spikes, the whole making a lovely display of color. The flowers are trumpet-shaped, with six petals well turned back; the color is intense orange scarlet ; a clump makes a very showy sight; also, used as a piece in a vase or basket, will attract great attention. South of Washington, D. C., the bulbs are perfectly hardy, and need not be lifted in Autumn. To cts. each ; 3 for 25 cts.; 12 for 75 cts.

\section{Zephyranthus.}

Candida.-The old-fashioned sort, and very fine. 5 cts. each; 6 for 25 cts.

Atamasco White.-At first a pale pink, changing to pure white. Io cts. each; 3 for $25 \mathrm{cts}$.; \$I per doz.

Atamasco Rosea.-A beautiful variety, upright flowers, petals broad and spreading; color lovely rosy pink. Ic cts. each; 3 for 25 cts.; \$I per doz.

The Set of 3 Zephyranthus for 25 cts.; 2 Sets 45 cts.; 5 Sets $\$ 1$.

\section{Apios Tuberosa.}

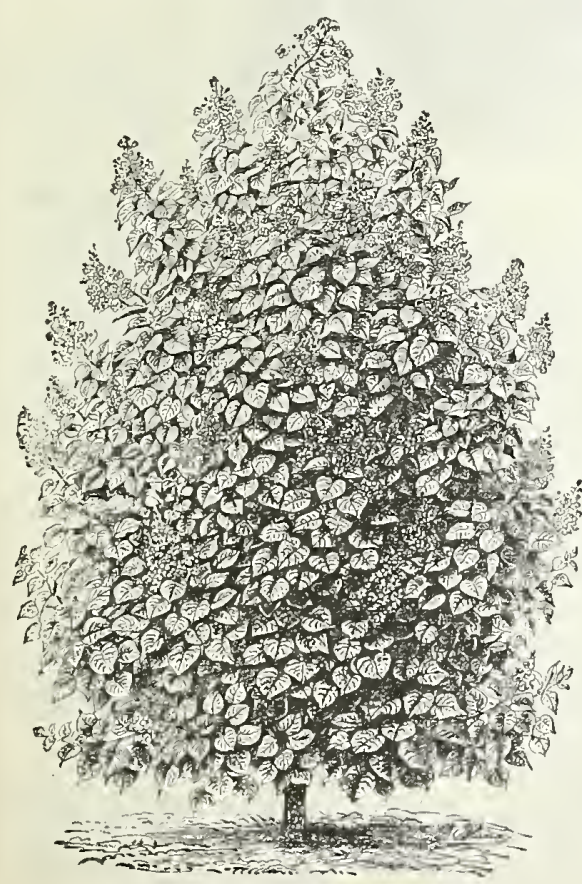

CATALPA, TEAS' JAPANESE HYBRID.

This valuable, hardy Tuberous-rooted climber is one of the most popular vines. Resembles the Wisteria in foliage. Produces in great profusion large clusters of rich purple flowers, delightfully fragrant. The bulbs are perfectly hardy, and stand the Winter; they bloom freely the first Summer. Io cts, each; 3 for 25 cts.; \$I per doz.

\section{Japanese Mybrid Catalpas.}

The new varieties of Catalpa have of late years become very popular. They are handsome, erect-growing trees of remarkably rapid growth; havelarge, luxuriant foliage, almost tropical in appearance, and bear immense clusters of large and handsome, dcliciously fragrant flowers.

\section{CATALPA, TEĀS' JAPANESE HYBRID,}

Is the newest and finest variety yet introduced. It has large heartshaped foliagc, and bears immense clusters of beautiful creamy white flowers, elegantly tinted with ycllow and purple, and shedding a delicious perfume all round; usually attains the height of 4 to 6 feet the first year, and blooms the second year from planting. Having stood a temperature of 20 to 25 degrees below zero without injury, it can safely be planted in the coldest sections of the United States, and is particularly recommended for its rapidity of growth, grent beauty and extreme hardiness. Price, strong transplanted plants (cut back), 25 cts.; 2 (or I each of both varieties), $40 \mathrm{cts.;} 6$ for \$I; \$2 pcr doz.

\section{CATALP K KEMPEFERII.}

This is another valuable Catalpa; a very strong, rapid and erect grower, decp glossy green lcaves and charming cream-colorcd flower followed by long narrow seed pods; makes an excellent tree for shade or timber; the wood is lasting and durable, and it grows so quickly that you can have shade and wood in a very little time; grows in all ordinary locations; requires no petting or special care of any kind; just keep it from injury and see it grow. Price, strong transplanted plants (cut back), 25 cts.; 2 (or I each of both varieties), 40 cts.; 6 for $\$ I$; $\$ 2$ per doz. 


\section{Our New Sweet Peas.}

UR Novelties and Special Selections of all the Newest and Choicest Sweet Peas the world over, have attracted widespread attention, flower people declaring that, for exquisite cherry fragrance, profusion of flowers and duration after cutting they could not be surpassed. Sweet Peas are first favorites with us, and we are ever
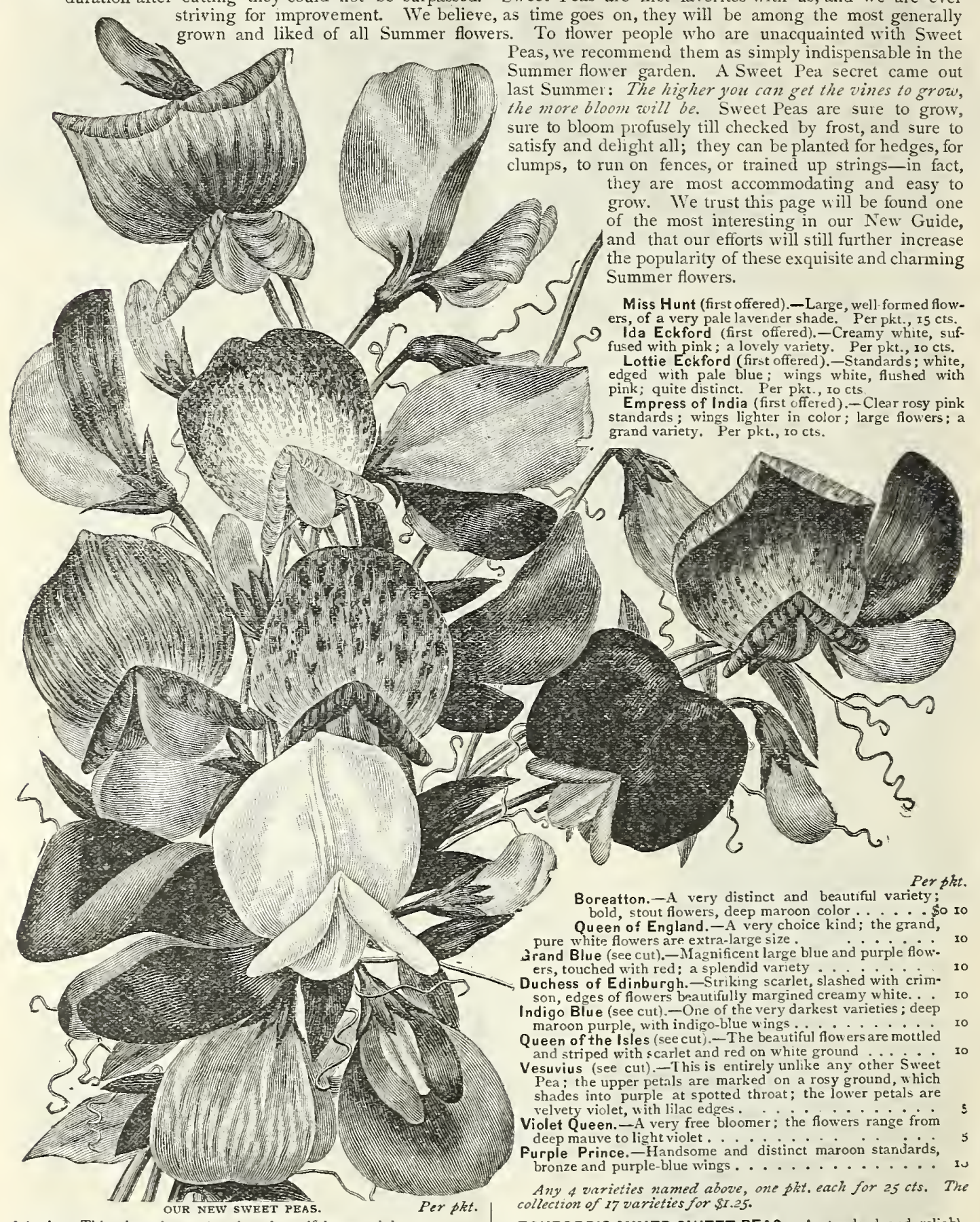

Adonis. - This charming variety is a beautiful rose pink, a new color in Sweet Peas. . \$ \$ Invincible Carmine(see cut)- From the celebrated English grower, Thomas Laxton, Esq. It is a rich, brilliant, growing carmine, and is the brightest colored Sweet Pea known; a dazzling sight
Bronze Prince. - This is a magnificent variety; large, wellBronze Prince. This is a magnificent variety; large, well-
formed flowers borne in great profusion: the upper petals are a rich, shining, bronzy maroon; the lower ones a deep royal purple color.

Splendid Lilac.-This is a distinct and lovely shade of color; flowers pretty, clear lilac. . . . . . . . . . . .

05

\author{
10
}

(10

5.

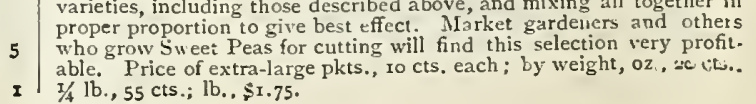
quality. Per plt., 10 cts.; oz., $20 \mathrm{cts}$.; $1 / 4 \mathrm{lb}$., $60 \mathrm{cts}$.; lb., $\$ 2$.

\section{Our flixed New Sweet Peas.}

This mixture cannot be equaled. It is made by taking 20 splendis This ming all together in per proportion to give best effect. Yrarket gardeners and others $1 / 4$ lb., 55 cts.; lb. . \$1.75.

Boreatton.-A very distinct and beautiful variety;

Boreatton.-A very distinct and Queen of England.-A very choice kind; the grand, pure white flowers are extra-large size . Arand Blue (see cut).- Magnificent large blue and purple flow:

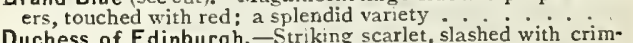
son, edges of flowers beautifully margined creamy white... Io Indigo Blue (see cut)-One of the very darkest varieties; deep

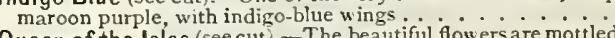
Queen of the Isles (see cut). - The beautiful flowers

and striped with scarlet and red on white ground .... esuvius (see cut).-This is entirely unlike any other Sweet Pea; the upper petals are marked on a rosy ground, which shades into purple at spotted throat; the lower petals are Violet Queen.-A very free bloomer; the flowers range from deep mauve to light violet. . distinct maroon stanuards, Furple Prince.-Hablue vings

Any 4 varieties named above, one pkt. each for $25 \mathrm{cts}$. The cllection of 17 varieties for $\$ 1.25$

ECKFORD'S MIXED SWEET PEAS. - A standard and relizble 


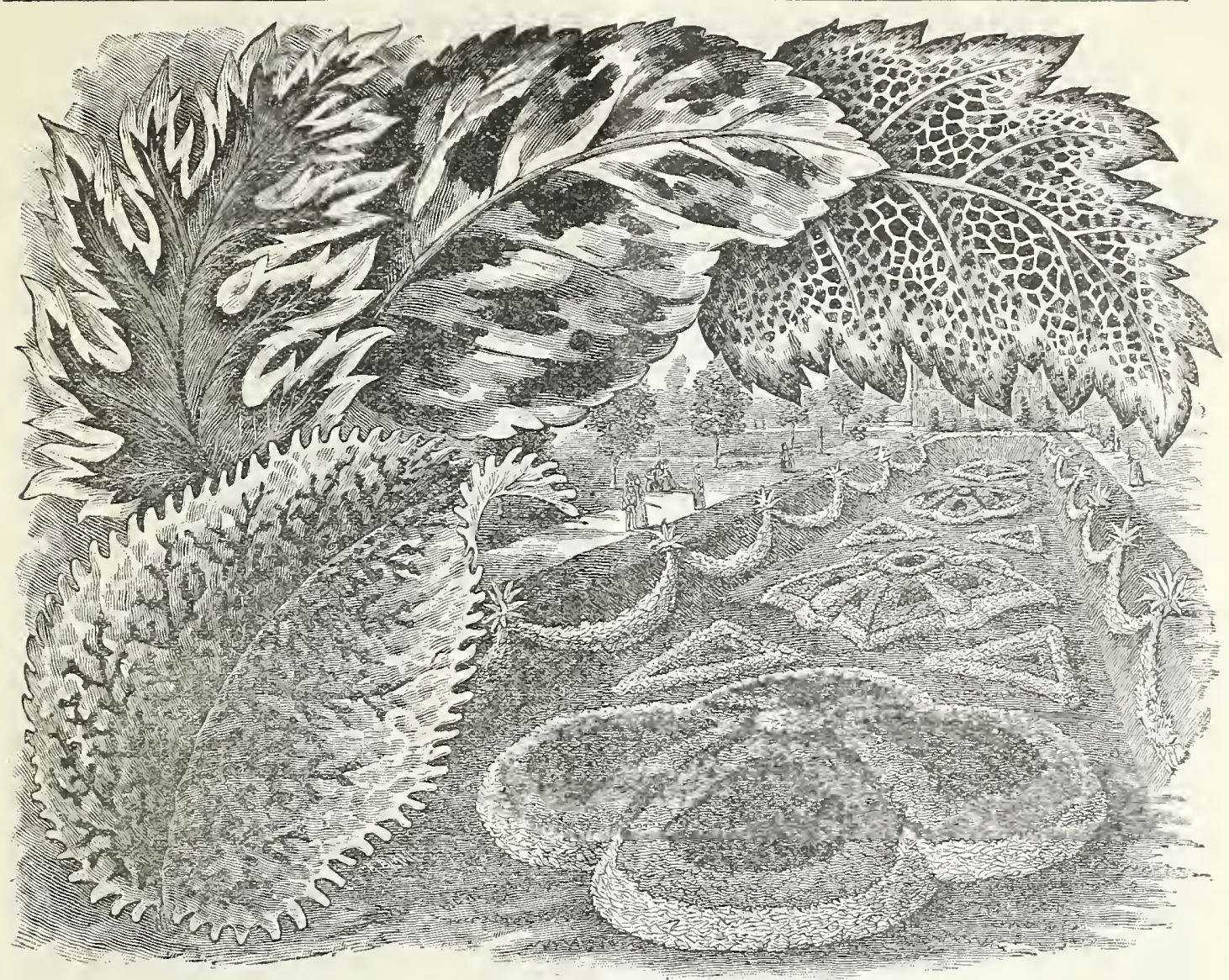

FRENCH BEDDING WITH SUCCESS COLEUS.

\section{Our Grand Success Coleus.}

A Selection of Coleus that can be grown to perfection from seed in a short sectson.

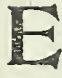

4

them. In fact, they are indispensable for brioht bedding effects, but to make any noticeable show requires a large number of plants, and, of course, corresponding expense. At last, we are glad to say, this expense is reduced to a minimum, as we have, and now offer for the first time, a special selection of Coleus seed that will produce vigorous and fine plants, showing the most perfect markings and colors, in a short season. We have named this valuable selection "Success
Coleus," as we are sure it will prove a success, surprise and delioht to all flower people. In our picture we had the artist show single leaves of four of the most distinctly colored and marked varieties; but every variation, color and inarking we lave ever seen in the finest assorted Coleus is included in the "Success Colezus." The directions for culture are extremely simple, as this strain of Coleus seed germinates easily, and success is as sure as with an ordinary annual. Start the seed in pots, boxes or pans, whichever is the most convenient, just as you would seed of any other tender plant that is usually started indoors. When the little plants show four leaves, thin out by transplanting a proportion to other pots, etc, and thus "Success Colcus
can be grown until the season for planting out in the open ground, which should not be done until all danger of frost is past. "The most fancifully designed beds and borders can be readily constructed of "Success Coleus," as the plants can be safely transplanted after the colors and markings begin to show. We have thoroughly graded and mixed "Sutccess
Coleus," and put it into liberal packets, so that a single packet can be depended on for a complete collection of colors and markings, and sufficient plants for a medium-sized bed.

Per pkt., 25 cts.; 2 pkts. for 50 cts.; 5 pkts. for $\$ \mathrm{r}$.

Our New Fancy Flowering Petunias.

This is the most costly and scarce seed we have, and until used, the stock is kept in our fireproof safe; as, in case of accident, it could certain high type, which is few seeded and the minute seeds carefully gathered by hand. The cost of production is so great that the crop is actually worth more than the same weight of gold. It is unquestionably the finest and most thorongh selection of Petunias in existence.
The colors range from pure white through delicate shades of rose, to deep pink; some flowers being marked and stained in the most beautiful manner, while the purple and dark colors are particularly rich and striking. Our mixture of seeds is made with care, so that a fine collecgood percentage of the most perfect double and fringed varieties is included, making altngether a selection that cannot fail to satisfy and delight all lovers of flowers.

Per pkt., 25 cts.; 3 pkts. for 60 cts.; 6 pkts. for $\$ \mathbf{I}$.
Blue Clematis, Flowered Petunia. This grand novelty will come true from seed. It is probably the most distinct in color of all Petunias; the flowers are of the largest size, deeply cupped, beautifully shaped, and of that magnificent dark
blue color for which the English Clematis Jackmanii is noted; ; a superb novelty. Per pkt, $5 \mathrm{cts}$.; 3 pkts, for 50 cts.

Torenia, Dwarf Compact.

We now offer, for the first time, a new selection of Torenia, which is vastly improved in habit over the old Torenia Fournieri. This new strain, which is named Divarf Compact, requires absolutely no supblooms from Summer until checked by frost. The flowers are lovely in shape and color, which is velvety blue, with three large spors of darkest blue, and bright yellow throat; charming for pot culture
vases or hanging baskets; also succeed well in the open ground Per pkt., 15 cts.; 2 pkts. for 25 cts. 


\section{$\rightarrow$ OUR STANDARD FLOWER SEEDS}

Below we offer an abridged list of the best Flower Seeds for general planting. Full descriftions and complete lists will be found in our New Guide, 110 pages, magnificently illustrated. If you have not a copy and desire one, ask for it zuken you order from this book.

ABUTILON-Best mixed...Per pkt. P. P. P.

AGAPANTHUS UMBELLATA

AGERATUM-Mexicanum

Tom Tbumb

ALYSSUM-

ASTER-Betteridge's Prize, mixed

Cocardeau or Crown, mixed.

New Comet

Diamond, mixed

Dwarf Pæony Perfection, mixed.

Goliath, Mont Blanc

New Dwarf Pouquet, mixed.

Three separate colors, each

New Dwarf Victoria, mixed. .

Queen of the Market.

Truffaut's Pæony Perfection, mixed

Victoria, mixed

Five separate colors, eacb

Prince of $w$, mixes

Fine mixed, for general planting.

AMARANTHUS-Splendens.

Salicifolins

Gaudatus.

Gibosu

BEGONIA-Tuberous-rooted, single

BEET-Scarlet Ribbed .

Yellow Ribbed

Dracana Leaved
BALSAM - Double Camellia-flowered.

Seven separate colors, mixed :

Choice double, mixed
CALENDULA-Meteor.

Prince of Orange

Best Double, mixed.

COREOPSIS-Golden Wave

CANDYTUFT-Pure White. .

Rocket

Extra Dark Crimson.

New Dwarf Hybrids

Best Mixed.

CELOSIA-New Dwarf Queen.

New Japanese Crimson

Empress

Glasgow Prize

Dwarf Varieties mixed

CHRYSANTHEMUM-Anulatum

Burridgeanum

Inodorum Plenissimum

Frutescens

Fine Varieties, mis:ed

COSMOS HYBRIDUS.

CYCLAMEN PERSICUM-Mixed

CUPHEA PLATYCENTRA.
CYPRESS VINE-Scarlet and White

Ivy-leaved

CENTAUREA-Kaiser Withelm

CINERARIA-Martinia

CLARKIA-Mrs. Langtry

CARNATION-Choice Double, mixed

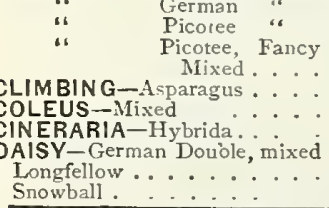

\section{Verbena Superfine.}

We offer the best and most carefully selected strain of Verberas ever sent out. This superb race of Verbenas embraces a remarkably large number of colors, shades and markings; the trusses or heads of flowers are very large, and are produced in great abundance from early Summer till late Fall. Verbenas raised from seed are quite fragrant, particularly so after sunset. The seed should be sown early in pots, boxes or hotbeds, and transplanted when 3 or 4 inches high. We have an unu-ually fine stock of seed; and have carefully made our mixture so as to include all the colors, shades and markings known to Verbenas. Per pkt., 20 cts.; 3 pkts. for 50 cts.; 7 pkts. for \$I; 15 pkts. for $\$ 2$.
Per pkt.

OXALis $($ Cont'd).-Valdivana $\ldots \ldots \ldots$

Floribunda

PANSY-Giant Odier Cassiers ..... Is

Dark Purple.

King of the Blacks

Light Blue

Lord Bcaconsfield.

Odier or Blotched.

English Face.

Prince Bismarck

Pure Yellow.

Quadricolor.

Silver Edge.

Snow Queen.

Striped and Mottled, mixed

Extra Large Flowering

Fine mixed, good quality

PRIMULA-Red.

Alba Magnifica.

Laringed, mixed.

PETUNIA New Duarf Inimitable".

Red Star.

Superfine, mixed

Good mixed, Importe

PERILLA-Nankinensis

PHLOX-Drummondii, mixed

Five separate colors, eacb

Grandifiora Varieties, Alba

Coccinea.

Carminea Alba Oculata

Splendens.

Stellata splendens

Quadricolor Resea
Rosemont, mixed.

Half Dwarf Varieties, mixe

PENSTEMON

POPPY -Carnation Double Duarf mixed Io Carnation Double Pæony Flowered.

PORTULACA-Finest Single, mixed.

Single, in five separate colors, each.

Grandiflora Double Orange.

Alba Oculata

Double Rose Flowered, mixed.

sTocks (German. Ten Weeks) -

Largest Flowering Dwarf Red. "W

Wall Flowered Leaved, fine mixed

Red Victoria

New Giant Perfection, mixed

Good Mixed Seed.

SWEET PEAS-Scarlet Striped

Black.

Light Blue and Purple

Butterfly

Painted Lady

Pure I

Eckford's Mixed

TROPAELUM-Majus, mixed.

I bbianum mixed

THUNBERGIA-Mixed

Bakerii.

VERBENA-Hybrida Auricula-Flow-

New Giant, mixed

Candidissima

Scarlet Defiance

Hybrida Superfine, mixed.

ZINNIA-New Pompone, mixed

Dwarf Snowball

" Fireball.

Double, mixed Giant.

\section{Besonia \\ New Begonia Vernon.}

Comes absolutely true from seed, and as it will stand our hot Summer sun, will prove of the greatest value for bedding and culture in the open ground. From seed started in February or MIarch, plants can be had tbat will begin to flower in early Summer, and continue in most striking effect until Autumn. The flowers are of an intense brilliant, deep-red color, which is magnificently set off by the abundant and vigorous foliage, which is stiff, glossy and of fine green color, partly margined with bronze purple. So easily raised from seed that we unreservedly recommend it both for bedding and pot culture. Per pkt., 15 cts.; 2 pkts. for 25 cts. 


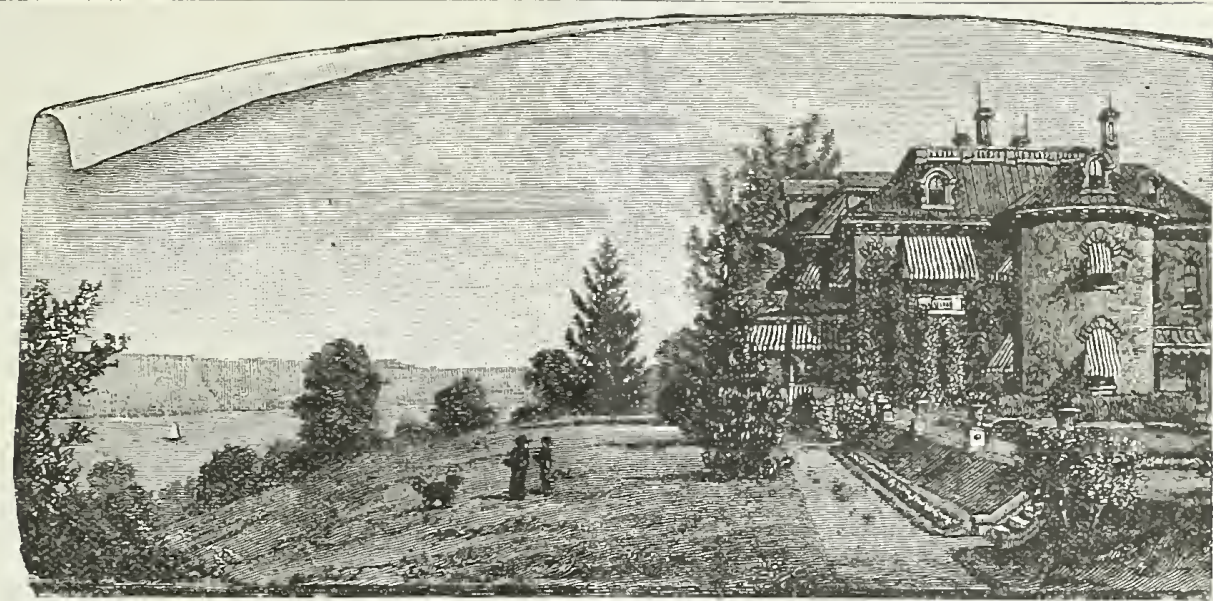

\section{The Dingee \& Conard Co.'s ROSEMONT LAWN GRASS SEED.}

A Special Mixture of the Best Natural Grasses for Making New Lawns and Renovating Old Ones.

I order to have fine permanent lawns and grass plots, it is of vital importance to have a careful blending of the most reliable grasses for this purpose. The matter of Lawn Grass is constantly receiving our best attention, and we are satisfied that our ROSEMONT LAWN GRASS here offered cannot be surpassed for quickly making a handsome, turfy sward that will stand our hot and dry Summers, presenting at all times a healthy and rich green color; also the strong vitality and excellent quality of this valuable Lawn Grass makes it particularly desirable for renovating old worn-out lawns that have grown thin and bare in places.

For laying down new lawns or plots, sow the seed at the rate of one quart to 300 square feet ( $15 \times 20$ feet), or five bushels to the acre; for renovating Lawns half this quantity is sufficient. Full directions for the laying down and care of lawns is sent with each order. We will also be glad to answer any inquiries in regard to the subject.

PRICE BY MAIL POSTPAID.-One quart, 30 cts.; four quarts, $\$ 1$.

We offer this seed in bulk by Express at \$1.25 per peck; one-half bushel, \$2.50; \$5 per bushel; 5 bushels for \$22.50.

\section{OUR NEW TOBACCO INSECTICIDE SOAP.}

We strongly recommend OUR NEW TOBACCO INSECTICIDE SOAP as the best and most reliable insect exterminator. It is absolutely safe to handle and will not injure the softest growth of plants. In fact it is a powerful fertilizer, leaves that have become wilted from the attacks of insects coming out frcsh and luxuriant. It is used by dissolving in hot or cold water, at the rate of one ounce to two quarts of water. With this liquid the plants should be frequently sponged, sprinkled or syringed. This new soap, besides being a valuable preventive of $\mathrm{mildew}^{\mathrm{e}}$, is Sure Death to most kinds of Injurious Insects, Bugs, Worms and Lice, which infest Growing Plants, Fruit. Trees and animals; apply a strong suds as often as necessary.

Every Cultivator of Plants should always have this Soap on hand. Horticulturists and others, who desire to buy a quantity, will please write for our lowest prices.

Price per can, by Mail, postpaid, 30 cts.; four cans for $\$ 1$. By Express, \$z per dozen cans.

GISHURST'S COMPOUND.-This wcll-known remedy HELLEBORE.-Unequaled for destroying Rose Slugs,

cannot be surpassed for preventing and destroying Green

Fly, Mildew, Thrip, Mealy Bug and Scale. With full dircc-

tions for applying. Per box, by mail, postpaid, $90 \mathrm{cts}$. Currant Worms, etc. One or two applications are usually sufficient for a season. With directions. Per lb., by mail póstpaid, $60 \mathrm{cts}$; per $2 / 2 \mathrm{lb}$., by mail, postpaid, $30 \mathrm{cts}$.

\section{A NEW ODORLESS FERTILIZER AND FOOD FOR PLANTS.}

The New Excelsior Fertilizer is just what has been wanted for a long time, and we strongly recommend its use to our many thousands of friends and customers. This new Odorless Flower Food is specially prepared for plants in pots, etc. It is in the shape of dry powder, put up in neat packages, to be used in liquid form. A quantity equal to a teaspoonful is dissolved in a pint of water, and applied about once a week to plants in pots, vases and hanging baskets; it will promote a healthy and vigorous growth of foliage, and on flowering plants abundance of bloom, at the same time driving worms and injurious insects from the soil. This valuable Fertilizer has no disagreeable odor, and takes the place of liquid manure, which is always sodifficult to cbtain and unpleasant to handle. We advise every one who grows flowers to give the New Excelsior Fertilizer a trial.

Priee, by Mail, Postpaid.-One package of 6 to 8 ounces for $20 \mathrm{cts}$; 4 packiages for $80 \mathrm{cts}$.

Price, by Express. - One pound, $30 \mathrm{cts}$; 3 pounds, $75 \mathrm{cts}$; 5 pounds, \$I.25.; ro pounds, \$2.25.

BOWKER'S AMMONIATED FOOD FOR FLOWERS. - This well-known and valuable Fertilizer is made especially for plants grown in the house, garden, or conservatory; clean, free from offensive odor, largely soluble in water, and producing healthy plants, FREE FROM VERMIN, and early and abundant blossoms, to which it imparts a rich and brilliant color. PRices-A PACKAgE, sufficient for 20 plants, three months, sent for 25 cents, postpaid; or a PACKAGE, sufficient for 20 plants, one year, sent for 50 cents, postpaid.

NOW READY, NEW AND REVISED EDITIONS OF POPULAR GARDENING BOOKS.

GARDENING FOR PLEASURE. - If you wish to cultivate Vegetables, Flowers or Fruits for private use, read the new and revised edition of "Gardening for Pleasure." This book treats of everything connected with Gardening indoors and out, and has been especially written for amateurs. $40+$ pages, illustrated. Price, $\$ 2$, postpaid, by Mail. PRACTICAL FLORICULTURE.- lf you desire to engage in the business of growing Cut Flowers or Plants for sale, we advise you by all means to read the New and Revised Edition of "Practieal Floriculture." 325 pages, fully lllustrated. Price, \$I.50, postpaid, by Mail.
ROSE CULTURE (Ellwanger).-A wcll-written and valuable work on Roses and their culture. \$I.25, postpaid.

THE GARDEN'S STORY (Ellwanger).-This thoroughly delightful book tells in the most charming manner how to enjoy the garden from the first rosy-cheeked Daphne till the last Monk's-hood Spire. \$r.25, postpaid.

MY HANDKERCHIEF GARDEN. - Size 20 x 60 feet. Result: A Garden, Fresh Vegetables, Exercise, Health and $\$ \mathbf{2 0 . 4 9}$. By Charles Barnard. Interesting and valuable. Price, 25 cts., postpaid. 


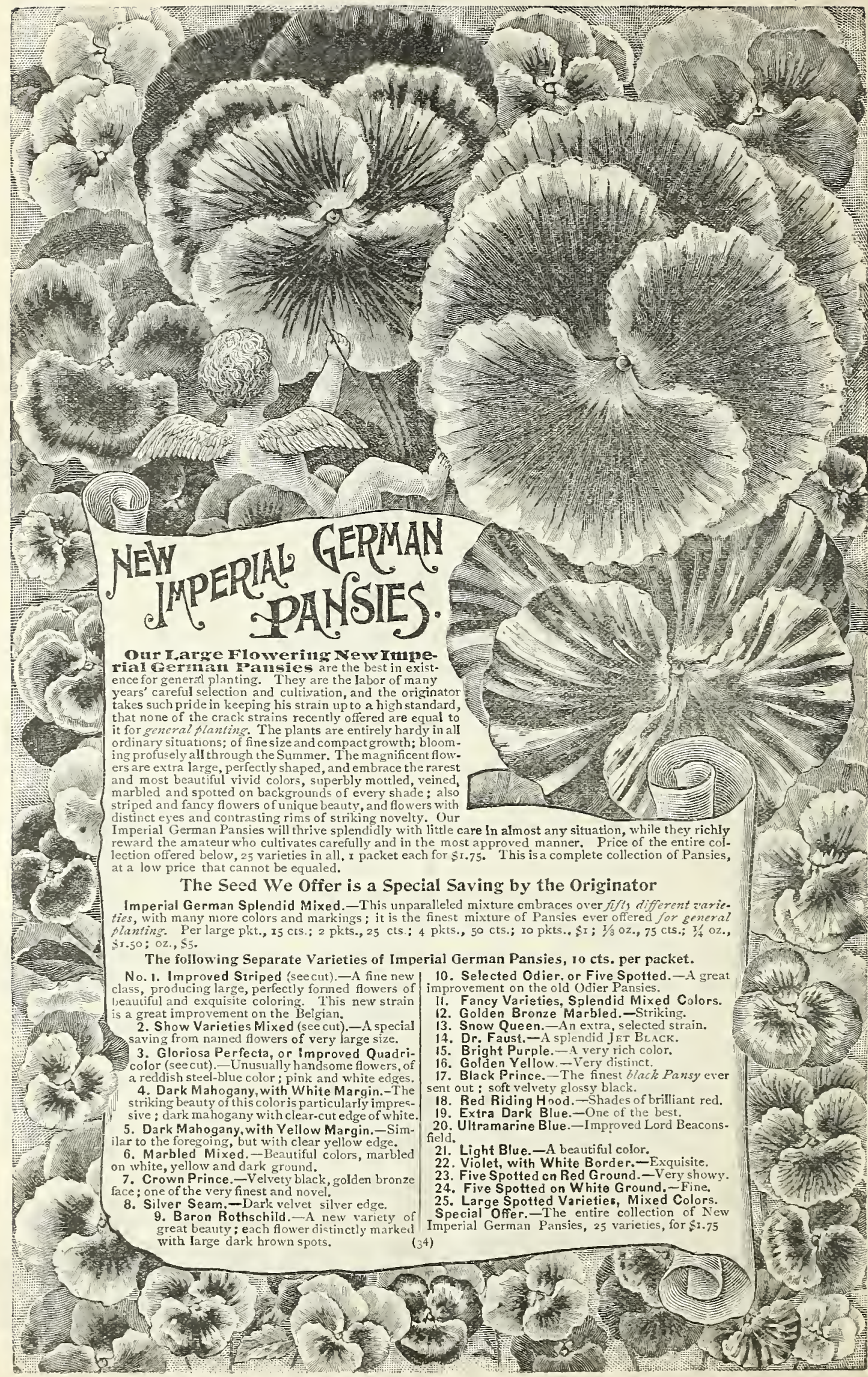



A zahproa

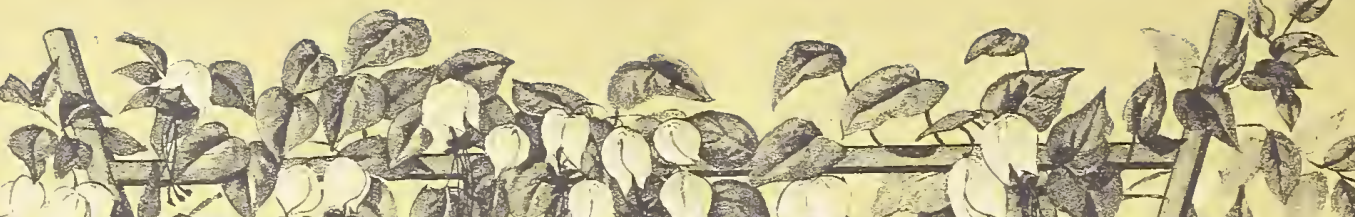
* 3 r a

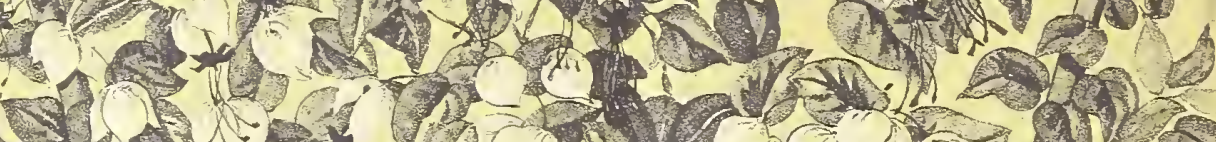

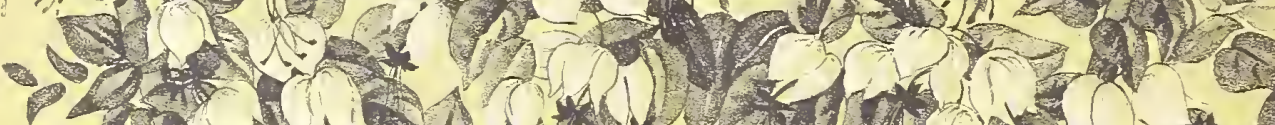
(1) $1.4 \times 12$

7.

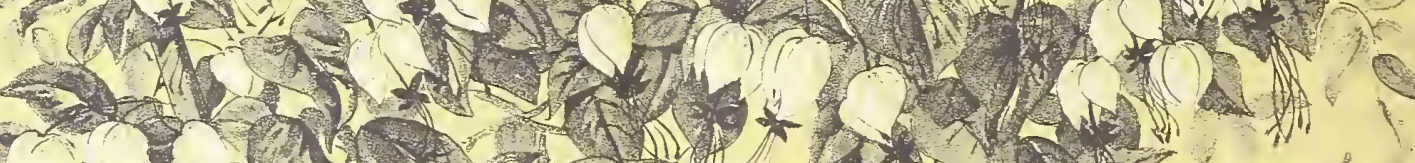

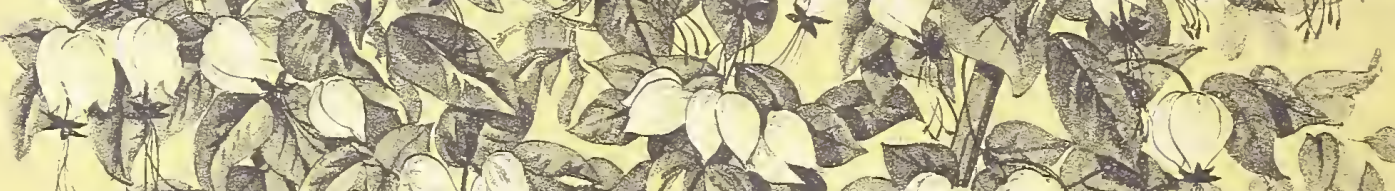

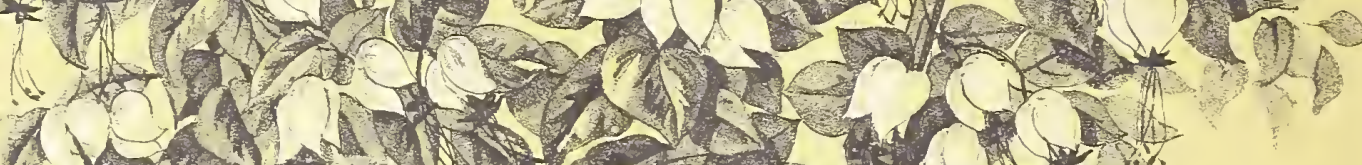

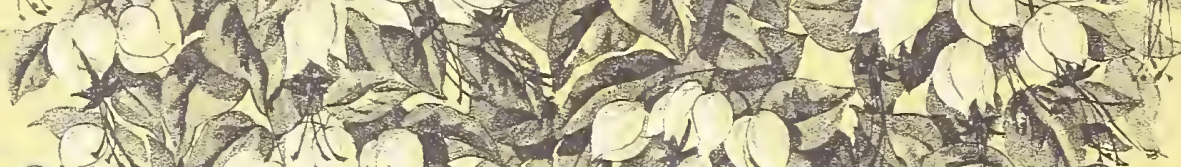

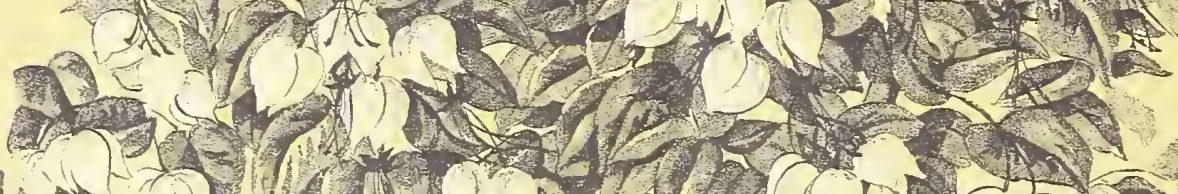

th

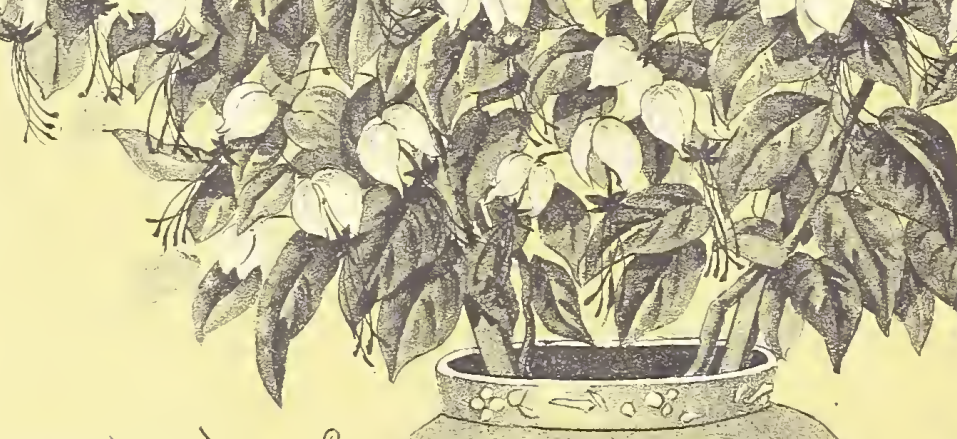

GLERODENIRON BALFOURI.

A GRAND PLANT FOR House gulture PRICE $30 \mathrm{CTS}$. EACH.

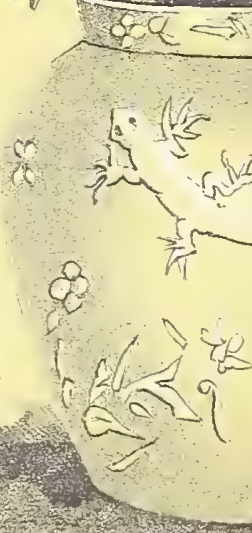

$$
\text { to }
$$
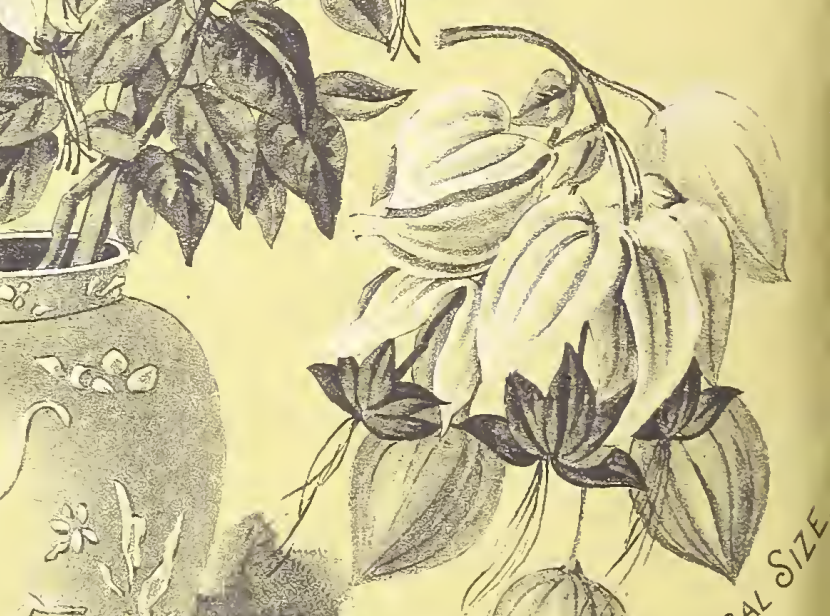

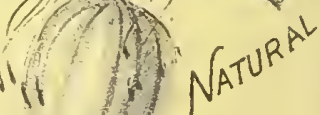

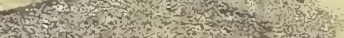

\section{G]1) Dinge of Golgard Gompany/
WEST GROVE. PA.}


